University of Louisville

ThinkIR: The University of Louisville's Institutional Repository

Electronic Theses and Dissertations

8-2012

\title{
The foundational structures behind Star Wars.
}

Aaron Nusz

University of Louisville

Follow this and additional works at: https://ir.library.louisville.edu/etd

Part of the Film and Media Studies Commons

\section{Recommended Citation}

Nusz, Aaron, "The foundational structures behind Star Wars." (2012). Electronic Theses and Dissertations. Paper 1075.

https://doi.org/10.18297/etd/1075

This Master's Thesis is brought to you for free and open access by ThinkIR: The University of Louisville's Institutional Repository. It has been accepted for inclusion in Electronic Theses and Dissertations by an authorized administrator of ThinkIR: The University of Louisville's Institutional Repository. This title appears here courtesy of the author, who has retained all other copyrights. For more information, please contact thinkir@louisville.edu. 


\title{
THE FOUNDATIONAL STRUCTURES BEHIND STAR WARS
}

\author{
By \\ Aaron Nusz \\ B.A., University of Louisville, 2004 \\ A Thesis \\ Submitted to the Faculty of the \\ College of Arts and Sciences of the University of Louisville \\ In Partial Fulfillment of the Requirements for the Degree of \\ Master of Arts \\ Department of Humanities \\ University of Louisville \\ Louisville, Kentucky
}

August 2012 
Copyright 2012 by Aaron Louis Nusz

All rights reserved 


\title{
THE FOUNDATIONAL STRUCTURE BEHIND STAR WARS
}

\author{
By \\ Aaron Louis Nusz \\ B.A., University of Louisville, 2004
}

A Thesis Approved on

April 22, 2012

By the following Thesis Committee:

Robert St. Clair, Thesis Director

\begin{tabular}{c}
\hline John Ferrè \\
\hline Mary Ann Stenger
\end{tabular}

Mary Ann Stenger 


\section{DEDICATION}

This work is dedicated to six different people.

First to my family:

My mother who always gave me all the love and tuna fish sandwiches I could ever need.

My father who is the greatest man I have ever known.

And Lauren, who is the love of my life.

Second to my committee:

To Dr. St. Clair who gave me the will.

To Dr. Stenger who taught me the words.

And to Dr. Ferrè who showed me the way.

May the force be with you all. 


\section{ABSTRACT \\ THE FOUNDATIONAL STRUCTURES BEHIND STAR WARS}

Aaron L. Nusz

April 22, 2012

The Star Wars franchise is one of the most successful film series of all time. The original three movies, along with the more recent three prequels, serve as the foundation to a vast empire of Star Wars television shows, action figures, comic books, and novels. Millions of people have already been exposed to these films, and millions more will be exposed to it in the future. With such a vast amount of people which continue to view these movies, it is easy to understand the impact Star Wars has had on our culture. But how did creator George Lucas sculpt this franchise? What were his influences when he created Star Wars? Researching this question by looking at the underlying structures led me understand the connections between literature, history, philosophy, and even mythology. This thesis shows the connections inherent in Star Wars and reveals why these movies are the way they are. 


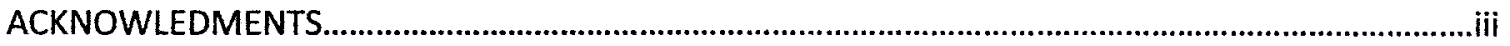

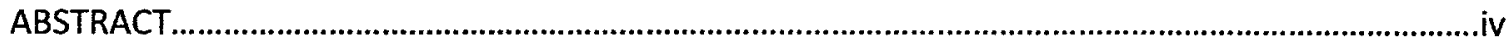

INTRODUCTION

THE PSYCHIC UNITY OF MANKIND

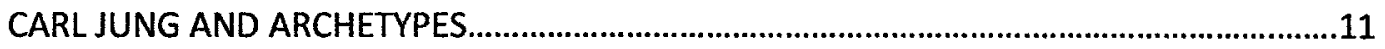

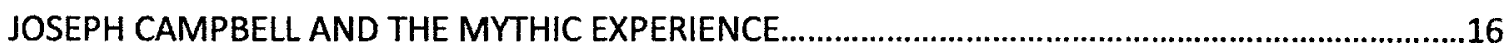

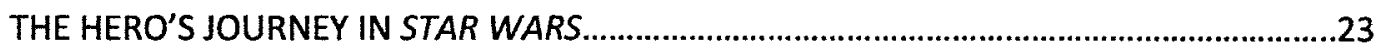

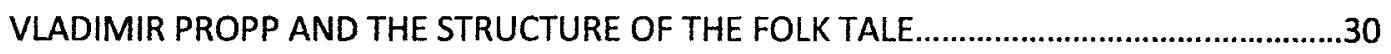

PROPPS' INFLUENCE ON THE WORK OF JOSEPH CAMPBELL...........................................33

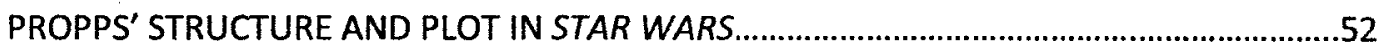

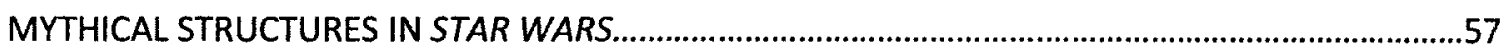

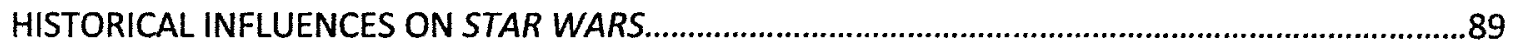

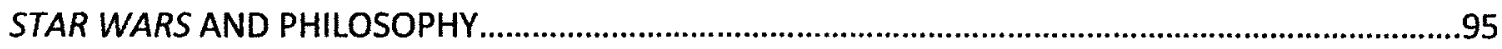

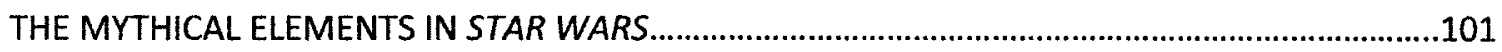

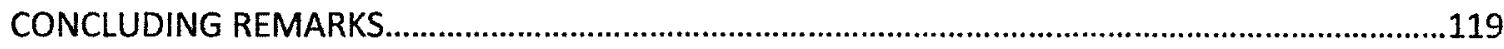

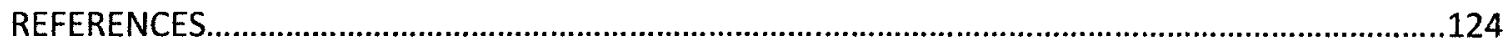

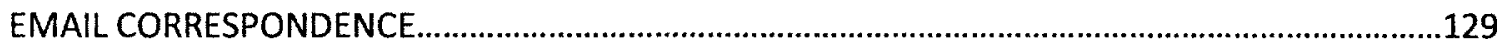

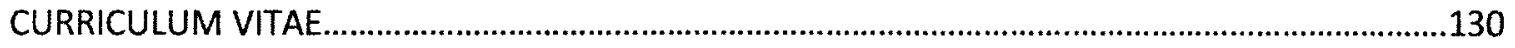




\section{CHAPTER I}

\section{Introduction}

The science fiction series, Star Wars, has been called an American epic by scholars, historians, and movie critics since it was first released in 1977. The space opera franchise was created by American film producer and screen writer George Walton Lucas Jr., who has an estimated net worth of $\$ 3$ billion as of $2010 .^{1}$

Lucas shaped every aspect of the Star Wars franchise including the characters, plot, and dialogue into a story that appeals to a large audience consisting of multiple ages, backgrounds, creeds, religions, and ethnicities. ${ }^{2}$ Star Wars follows the structural tradition of story-telling explained in the writings of Joseph Campbell. ${ }^{3}$ In many different interviews Lucas has stated unequivocally that he used Joseph Campbell's work as a model for the Star Wars movies. ${ }^{4}$ Multiple scholarly works have shown the multiple connections between Campbell's and Lucas's works.

What has not been sufficiently elaborated upon, however, are the influences contained within the work of Campbell. When writing his theories about the universality of myths, Joseph Campbell was influenced by the works of Adolph Bastian and Carl

\footnotetext{
1 "George Lucas ranks 316 on The World's Billionaires 2010," Forbes (October 3, 2010).

2 Joel Martin and Conrad Ostwalt Jr., Screening the Sacred: Religion, Myth, and Ideology in Popular American Film (Boulder: Westview Press Inc., 1995) 73.

${ }^{3}$ Joseph Campbell, The Hero with a Thousand Faces (Princeton: Princeton University Press, 1973)

${ }^{4}$ Star Wars Trilogy, Special Edition, Dir. George Lucas (Fox Searchlight Studios and Lucasfilm Ltd., 1995).
} 
Jung. ${ }^{5}$ It is important to study and understand the influences on Campbell in regard to the structure of Star Wars because, as Campbell himself pointed out, mythological archetypes and structures are not the only ideas that are duplicated in scholarly works. In his book The Hero with a Thousand Faces Campbell states:

As Dr. Jung points out (Psychology and Religion, par. 89), the theory of the archetypes is by no means his own invention... he has borrowed his term archetype from classic sources: Cicero, Pliny, the Corpus Hermeticum, Augustine, etc. Bastian notes the correspondence of his own theory of "elementary ideas" with the Stoic concept of the Logoi spermatikoi. The tradition of the "subjectively known forms is, in fact, coextensive with the tradition of myth, and is the key to understanding the use of mythological images..."6

Just as it is important to study the influences on Star Wars to better understand the work, so too is it equally important to study the foundations of those influences. The work of Vladimir Propp will also be discussed because while the work of Campbell was groundbreaking in its own right, the work of Propp pre-dates the work of Campbell by almost thirty years. While Campbell did not directly rely on the work of Propp, Propp's work was very influential to scholars around the world and much of his work did find its way into the Star Wars movies. Without the foundation of Bastian and Jung along with the influence of Propp, Campbell would have been unable to create his own theories of the universality of mythological traditions. By understanding the foundations and influences upon Campbell, we can begin to understand how Campbell's mythological model took shape. By understanding these foundations and influences of Campbell's work we can begin to understand Campbell's attitude toward certain mythological devices. For example, the Campbell model of the mythological tale often treats the father

\footnotetext{
${ }^{5}$ Joseph Campbell, The Hero with a Thousand Faces (Princeton: Princeton University Press, 1973).

${ }^{6}$ Joseph Campbell, The Hero With a Thousand Faces (Princeton: Princeton University Press, 1973).
} 
of a heroic figure as an opposing force. ${ }^{7}$ In the Campbell model of the mythological tale, the father figure is often a hindrance rather than a help to the heroic figure. Why? Because Carl Jung in his writings of archetypes often saw the relationship between parents and children as being one of conflict $^{8}$ and so as a result one of the stages of Campbell's heroic journey became "atonement with the father." And as a result, filmmaker George Lucas fashioned one of the main conflicts of Star Wars around Luke the son and Vader the father. It is by understanding the theories of Jung that we gain understanding about the relationship between Luke and Vader.

Hence, part of this thesis is on how that tradition helped structure the Star Wars movie franchise. In this regard Lucas believed the claim that myths from all over the world appear to be fabricated from the same "elementary ideas." 10 This concept can be traced back to Adolph Bastian who believed in the unity of mankind. ${ }^{11}$ Bastian believed that various cultures evolved along the same lines, and therefore the stories, folklore and beliefs of people were fundamentally the same. The differences between stories, folklore and beliefs could be traced to the differing geographic locations of the various cultures. Carl Jung, a Swiss psychiatrist, was influenced by Bastian and named these elementary ideas "archetypes." For Jung these basic ideas formed the building blocks of the unconscious mind. ${ }^{12}$ Author Joseph Campbell later used this concept of the psychic

\footnotetext{
${ }^{7}$ Joseph Campbell, The Hero With a Thousand Faces (Princeton: Princeton University Press, 1973) 5-7.

${ }^{8}$ Anthony Stevens, Archetypes: A Natural History of the Self (London: Routledge \& Kegan Publishers Ltd., 1983) 92.

${ }^{9}$ Joseph Campbell, The Hero With a Thousand Faces (Princeton: Princeton University Press, 1973) 126.

${ }^{10}$ Star Wars Trilogy, Special Edition, Dir. George Lucas (Fox Searchlight Studios and Lucasfilm Ltd., 1995).

${ }^{11}$ Edward B. Tylor. "Professor Adolf Bastian." Man (Issue 5, 1905) 138-143.

${ }^{12}$ Klaus-Peter Koepping, Adolf Bastian and the Psychic Unity of Mankind: The Foundations of Anthropology in Nineteenth Century Germany (St. Lucia: University of Queensland Press, 1983).
} 
unity of mankind in The Hero with a Thousand Faces, a book that had a great impact on Lucas. Hence, these scholars laid the foundation upon which Star Wars was based.

The questions that need to be asked are: How closely were these concepts used by Lucas? And how greatly was the work of Campbell influenced by the work of his predecessors? In this thesis several myths used by Campbell and Lucas are investigated and compared. Prior to this analysis, however, it is necessary to look at the work of Bastian, Jung, Propp, and Campbell and elaborate on their main ideas and how they influenced the making of Star Wars. Discussions will include, for example, the work of the Russian Formalist, Vladimir Propp and his theory of the structure of the folk tale. This work is important because it provides the formula upon which the genera of the epic of Star Wars are predicated. It is also important because it creates a structural model of the hero and his quest. Propp worked with fairytale stories and believed that each of these contained the same basic thirty one parts. It is from these parts that many parallels can be drawn to both Campbell and Lucas.

Finally, the role that visual metaphors play in the film is discussed. This section will discuss the structure of analogical reasoning within the film work of George Lucas. In some cases, Lucas has modernized these mythical structures and in other cases he has not. These changes are discussed.

Star Wars embodies multiple philosophies, mythological stories, scholarly ideas, theatrical traditions, and even religious beliefs. It has been well established that George Lucas relied on the theories of author Joseph Campbell. Campbell in turn drew upon the psychology of Adolph Bastian and Carl Jung. The literary approach of Vladmir Propp 
was influential to the academic community as a whole if not Campbell specifically. ${ }^{13}$ Therefore not only can the influences of Campbell be found within Star Wars, but the work of Bastian, Jung and Propp as well. When viewed in this way, the Star Wars movies become a symphony of multiple influences. The examination of these influences is the purpose of this thesis.

Chapter One will discuss the underlying psychological framework of the Star Wars saga. The work of Carl Jung and Adolph Bastian will be discussed in reference to how they influenced the work of Joseph Campbell which then in turn influenced creator George Lucas. The work of Jung, for example, greatly influenced Lucas's creation of his characters within Star Wars as he modeled many of their features after Jungian archetypes.

Chapter Two will examine the work of Vladimir Propp. And while Propp did not have a direct influence on the creation of Star Wars, his insight into the fairytale and folklore stories are of great importance to the greater understand of these movies. Like Joseph Campbell, Propp outlined a series of stages that a story would go through from beginning to end. Remarkably, many of the stages Propp describes decades before appear in both the work of Campbell and later Lucas.

Chapter Three will focus on the mythical structures found with the Star Wars film franchise. This chapter will map the various stages Joseph Campbell describes in his book The Hero with a Thousand Faces and will illustrate how these stages are mirrored within the Star Wars saga. The journey a hero takes within a quest story, Campbell argues, is basically the same regardless of the time, time, or culture which gave that story

\footnotetext{
${ }^{13}$ Steven Swann, The Fairy Tale: The Magic Mirror of the Imagination (London: Routledge, 2003).
} 
birth. Structurally, then, Roman myths are the same as Egyptian myths, which are the same as Celtic myths, all of which are the same as the Star Wars myths.

Chapter Four will examine the historical influences contained with the Star Wars movies. Jung, Bastian, and Campbell were not the only influences Lucas drew upon when shaping his space opera stories. He also drew on a wide variety of historical influences which included World War I, the Space Race between the United States and Russia, as well as other more subtle influences such as the movie serials Lucas grew up watching in the $1950 \mathrm{~s}$.

Chapter Five will focus on the philosophical elements of the Star Wars storyline. Concepts such as the "Force" and destiny which are prevalent in Star Wars have their roots in both Eastern and Western philosophical traditions. These connections are explored within this chapter with special emphasis being placed on the religious philosophical implications contained within the movies.

Chapter Six will discuss the various other mythical elements that can be found within the stories of Star Wars. These are elements which are somewhat separate from the overriding quest aspect of the story but which are still key components to a myth story. In many mythological traditions, for example, a hero will often consult an oracle or soothsayer, or some other type of seer which will give the hero some type of guidance. Star Wars does contain this, and other such mythical elements all of which are discussed in this chapter.

The overriding theme of this thesis is the parallels one can draw between Star Wars and other things. Some of these parallels were placed in the story purposefully by George Lucas as the story took shape. Others exist because as a human species we often 
recreate similar stories over and over. There is no question that Star Wars has become a part of the world culture. It is important, then, to understand what Star Wars means beyond a wildly successful movie franchise. This thesis seeks to understand Star Wars deep below the surface. 


\section{CHAPTER II}

\section{THE PSYCHIC UNITY OF MANKIND}

It was on the wealth of mythological traditions espoused by Adolph Bastian that Lucas based Star Wars. Bastian advocated for what he termed the "psychic unity of mankind."14 He believed that all humans share a basic mental framework. He espoused an evolutionary model of mankind in which the world was divided up into different geographical provinces that moved through the same stages of evolutionary development. He argued against cultural diffusion and believed that innovations and cultural traits tended not to diffuse across areas. He accounted for cultural change by arguing that each province took its unique form as a result of its environment. ${ }^{15}$ This approach is reminiscent of the comparative method espoused by Edward B. Tylor, the advocate of primitive anthropology. Bastian argued that all humans everywhere in the world are products of physiological mechanisms that affect the genetic system so that every human mind inherits a complement of species specific "elementary ideas" (Elementargedanken). ${ }^{16}$ From this "inheritance" of elementary ideas he concluded that the minds of all people function or operate in the same way regardless of their race or culture. For example, a smile always signifies a good mood regardless of a person's

\footnotetext{
${ }^{14}$ Edward B. Tylor. "Professor Adolf Bastian." Man (Issue 5, 1905) 138-143.

${ }^{15}$ Edward B. Tylor. "Professor Adolf Bastian." Man (Issue 5, 1905) 138-143.

${ }^{16}$ Edward B. Tylor. "Professor Adolf Bastian." Man (Issue 5, 1905) 138-143.
} 
specific culture. Bastian believed that the meaning of the smile is universal, for nowhere does a smile symbolize sadness, or anger, or any emotion other than happiness.

According to Bastian, the combination of geographic location and historical background creates different kinds of elementary ideas. He called these local elaborations "folk ideas" (Volkergedanken). Over time, these ideas become more complex and develop into group thinking or a collective mind. ${ }^{17}$ It is this idea that Carl Jung employed in his theory of a collective unconsciousness. As author Dr. Anthony Stevens said in his book Archetypes:

Jung was encouraged towards the formulation of the archetypal hypothesis much in the same way as inferred the existence of Elmentargedanken, though Jung did not confine himself to folklore and anthropology... Like Bastain, he was struck by the way in which analogous motifs cropped up in the most diverse cultures, as far removed from each other in geography as they were in historical time: in other words, he noted that mythological and religious themes were, as the ethologists say, 'environmentally stable. 18

In this social soul (Gesellschaftsseele), the individual mind is embedded. Jung wanted to develop a theory of collective representations (Gesellschaftsgedanken).

Why is the work of Adolf Bastian important to the foundations upon which Star Wars was created? It is important because the belief in the psychic unity of mankind was fully articulated by Bastian and this concept led to the concept of Jungian archetypes and these archetypes had a great impact on the thinking behind the work of Joseph Campbell. George Lucas, in turn, not only read Campbell's work, but met with him many times to discuss his concepts and how they could be incorporated into his films. ${ }^{19}$ The work of Bastian and Jung can both be found in Star Wars because their work influenced Joseph

\footnotetext{
${ }^{17}$ Edward B. Tylor. "Professor Adolf Bastian." Man (Issue 5, 1905) 138-143.

${ }^{18}$ Anthony Stevens, Archetypes: A Natural History of the Self (London: Routledge \& Kegan Publishers Ltd., 1982) 40.

19 Joseph Campbell, and Bill Moyers, The Power of Myth, by Joseph Campbell, (New York: Random House Inc., 1991) ix.
} 
Campbell who later influenced George Lucas. Bastian leads to Jung, which leads to Campbell and then on to Lucas. Campbell himself cited the work of Jung a total of fifteen times in The Hero With a Thousand Faces. As each creator was influenced by previous work, some changes were made along the way. Campbell, for example, distilled the works of Bastian and Jung in his writing where he discards some pieces (Jung's archetype of the Joker for example) while diluting others (such as Bastian's theory of evolutionary unity). ${ }^{20}$ Lucas likewise altered the stages of Campbell's stages of the heroic journey by having some stages occur before others (such as "meeting of the goddess" which occurs early in Star Wars but is a later stage in Campbell's model). ${ }^{21}$

While many scholarly works have examined the connection between Campbell and Lucas, most ignore the fact that the work of Campbell was largely influenced by others, especially Bastian and Jung. The theories of Campbell's heroic journey could not exist without the influences of these previous works. Campbell specifically cites both Bastian and Jung in The Hero With a Thousand Faces. The work of Vladimir Propp was influential to the academic community as a whole, and while there is no direct evidence that Campbell ever specifically relied on Propp's theories (he never for example cited Propp as a source in any of his work), Morphology of the Folktale was a seminal book that aided in the study of mythological stories. Because of the huge impact Propp's work had, and the similarities that exist between it and Star Wars, it warrants study in this thesis.

\footnotetext{
${ }^{20}$ Joseph Campbell, The Hero With a Thousand Faces (Princeton: Princeton University Press 1978) 3-25.

${ }^{21}$ Star Wars: A New Hope, Dir. George Lucas (Fox Searchlight Studios and Lucasfilm Ltd., 1977)
} 


\section{CARL JUNG AND ARCHETYPES}

Carl Jung plays an important role in the creation of Star Wars because he not only incorporated the philosophy of Bastian into his own metaphysics, but he also developed his concept of the archetypes around $1919 .^{22}$ These archetypes were the basis for the characters George Lucas created in the Star Wars franchise. The Self, Shadow, Anima, Animus, and Persona archetypes are all character traits which are found within Star Wars. Jung argued that these archetypes were innate, universal prototypes for ideas which were preconditioned and coexistent with all life. ${ }^{23}$ In his reformulation, he argued that the group of memories and interpretations associated with an archetype forms a complex core. This core constitutes a pattern of emotions, memories, perceptions, and wishes in the personal unconscious that are organized around a common theme. For example, a mother complex associates with the mother archetype. ${ }^{24}$ Just as Adolf Bastian advocated an evolutionary model for his elementary ideas, Jung promoted a similar model for his archetypes. He treated the archetypes as psychological organs and claimed that these were analogous to physical organs in that both are morphological forms which arose through evolution. Jung outlined five main $\operatorname{archetypes}^{25}$ :

\footnotetext{
${ }^{22}$ Anthony Stevens, Archetypes: A Natural History of the Self (London: Routledge \& Kegan Publishers Ltd., 1982).

${ }^{23}$ Anthony Stevens, Archetypes: A Natural History of the Self (London: Routledge \& Kegan Publishers Ltd., 1982) 29.

${ }^{24}$ Anthony Stevens, Archetypes: A Natural History of the Self (London: Routledge \& Kegan Publishers Ltd., 1982) 85-103.

${ }^{25}$ Each of these archetypes have been used in multiple works of both Jung, and those who study his work. The main source used in this thesis for the understanding of the Jungian archetypes is by Anthony Stevens, Archetypes: A Natural History of the Self (London: Routledge \& Kegan Publishers Ltd., 1982).
} 
- The Self is the regulating center of the psyche that facilitates the process of the individual, which is the amalgam of the animus and the anima. According to Greek mythology, man and woman were originally united into one body with each facing back to back. The other gods were jealous of them and separated them into the male animus and the female anima. Since then, Jung argued, man and woman have attempted to unite in the process of becoming one again (individuation).

- The Shadow is best explained by followers of Jung who use his model of psychological types. One develops a strong psychological type such as the intuitive type who always looks for main ideas in dealing with others. This person may develop secondary or tertiary psychological types such as an intuitive or a feeling type, but that individual will always have a weakness that Jung calls the Shadow. The sensate type is the shadow of the strong intuitive type; the feeling type is the shadow of the strong thinking type; the thinking type is the shadow of the strong feeling type; and the intuitive type is the shadow of the strong sensate type. People, Jung argued, are always attracted to their shadows. This is what he meant by his claim that in relationships opposites attract.

- The Anima is the female image that exists in a man's psyche. A man must embrace the female in himself in order to become individuated. In fairy tales, the male hero needs to fall in love with the female princess. She awakens the anima within him.

- The Animus is the masculine image within a woman's psyche. Just as the male contains an anima within himself, a woman contains an animus within herself. In 
order for her to become whole (individuated) she must have that archetype activated. For example, the DC comic book character Wonder Woman represents an individuated woman who has developed and nourished the animus within her.

- The Persona has to do with how one presents himself to the world. It protects the Ego from negative images. Persona in Greek means "mask" and this archetype acts like a mask to protect the fragile Ego.

Jung went on to explain that archetypes can take on many different forms which he called recurring archetypal images which occurred because of the "collective unconscious" which all people are a part of. ${ }^{26}$ Some of these recurring images were used by George Lucas in Star Wars. Jungian archetypes became a part of Star Wars because Lucas used the work of Campbell who in turn had based much of his theories on the work of Carl Jung. An example of Jungian archetypes can be seen when analyzing the character Darth Vader. Vader is a Persona Jungian archetype in the Star Wars franchise. "Persona" is the Greek word for "mask" which is the number one defining characteristic of Darth Vader. Physically Vader has to wear a complete body mask to cover his injuries and sustain his life. On a psychological level, Vader also wears a mask which hides his good nature buried beneath the outwardly evil personality.

The most common hero in Greek mythology was a demigod and one of the most distinctive features of the hero or the heroine was the fact that such a person faces danger and adversity from a position of weakness and who has the courage and the will for self sacrifice to overcome these dangers for the greater good of all humanity. In Greek

\footnotetext{
${ }^{26}$ Anthony Stevens, Archetypes: A Natural History of the Self (London: Routledge \& Kegan Publishers Ltd., 1982) 14.
} 
literature, Heracles, Perseus, and Achilles were all deemed heroes. ${ }^{27}$ In Star Wars, Luke Skywalker, played by Mark Hamill, is portrayed as a hero. George Lucas used him an archetypal image in the Jungian sense. In effect, Lucas created a new Greek hero in the form of Luke Skywalker.

The Wise Old Man or the Sage is another archetype. This type of character is typically represented as a kind and wise, older father figure. The Sage archetype personifies wisdom. He uses the personal knowledge of other people and of the world to tell stories and by means of these stories he offers them guidance. He acts as a mentor to them. ${ }^{28}$ In Star Wars, the wise old man archetype is personified by Obi Wan Kenobi, played by Sir Alec Guinness. In his role as the Wise Old Man, Kenobi imparts upon Skywalker information and skills needed to complete the heroic journey.

Many other Jungian archetypes found their way into Star Wars via Joseph Campbell and these will be elaborated on later in the section of the paper that discusses the film in greater detail. However a far more interesting Jungian contribution has to do with the concept of the archetypes of transformation. Transformative archetypes became a part of the Star Wars movies because Campbell used them in his work on the heroic journey. Campbell saw the heroic journey as a process that took a person who was someone ordinary at the beginning of the story, and transformed them into someone extraordinary by the end. ${ }^{29}$ Jung was interested in how archetypes exist as energy and he chose situations, places, and persons who symbolized these transformations from within. Later, in the discussion of plot theory, these archetypes of transformation will be exemplified in

\footnotetext{
${ }^{27}$ Edith Hamilton, Mythology (New York: Little, Brown and Company Publishers, 1998).

${ }^{28}$ Anthony Stevens, Archetypes: A Natural History of the Self (London: Routledge \& Kegan Publishers Ltd., 1982) 180.

${ }^{29}$ Joseph Campbell, The Hero with a Thousand Faces (Princeton: Princeton University Press, 1973) 246.
} 
the Quest Plot which involves personal transformations of the self from one stage of growth to another. 


\section{CHAPTER III}

\section{JOSEPH CAMPBELL AND THE MYTHIC EXPERIENCE}

- Another part of the philosophical tradition that Lucas followed came from the works of Joseph Campbell. The contribution that Campbell made to the theory of archetypes was significant. He took the idea of archetypes and used them to map out the common underlying structure behind religion and myth. He proposed this idea in his book The Hero with a Thousand Faces. In this work, Campbell provided numerous examples from different cultures and throughout history as evidence of his claim. He eloquently demonstrated that all of these stories are expressions of the same story-pattern (the monomyth), which he named the "hero's journey."30 What one finds in this simple idea is the claim made by Adolf Bastian that basic ideas are repeated through life and that these ideas constitute some kind of collective consciousness. Following this reasoning Campbell claims that all religions are really containers for the same essential truth. ${ }^{31}$

Campbell believed that when one participated in ritual, a person could directly experience mythic reality, and this was a common theme which appeared repeatedly in his six-part interview on the Power of Myth with Bill Moyers on television. ${ }^{32}$ The interviews in the first five episodes were filmed at George Lucas's Skywalker Ranch in

\footnotetext{
${ }^{30}$ Joseph Campbell, The Hero with a Thousand Faces (Princeton: Princeton University Press, 1973) 3-46.

${ }^{31}$ Joseph Campbell, The Hero with a Thousand Faces (Princeton: Princeton University Press, 1973) 156$159,389-390$.

${ }^{32}$ Joseph Campbell and Bill Moyers discussed ritual many different times throughout the interviews. Of particular interest to this thesis is the discussion of how movies (specifically scary and sci-fi oriented genres) can sometimes supplement ritual in a modern culture. See Joseph Campbell and Bill Moyers, The Power of Myth (New York: Random House Inc., 1988) 101-104.
} 
California, with the sixth interview conducted at the Museum of Natural History in New York. The entire interview took place over time during the final two summers of Campbell's life and the series was broadcast on television a year after his death. In these discussions, Campbell presented his ideas about comparative mythology and the ongoing role of myth in human society. In these talks Campbell included excerpts from his work The Hero with a Thousand Faces. In the first episode of the series, Campbell discussed Star Wars. ${ }^{33}$ Campbell and Lucas became friends after Lucas publicly announced that Campbell and his work on comparative mythology played a major role in his making of Star Wars. George Lucas deliberately used Campbell's theory of the monomyth in the making of the Star Wars movies. In addition, Lucas, himself, gave an extensive interview for the documentary The Mythology of Star Wars with interviewer Bill Moyers on this topic. ${ }^{34}$ It was in this interview that he stated that at one point in his career he came to believe that there was no use of mythology in his films. Later he began to do serious research into fairy tales, folklore, and mythology. During this period he began to read Joseph Campbell. It was in reading The Hero with a Thousand Faces that he began to realize that his first draft of Star Wars followed the classic motifs outlined by Campbell. ${ }^{35}$ Hence, Campbell's work shaped Star Wars.

While Lucas did not follow the heroic journey that Campbell laid out verbatim, he did follow the general structure, archetypes, and plots Campbell discussed in his work. George Lucas realized that by following the model of Campbell, he could create a story

\footnotetext{
${ }^{33}$ Joseph Campbell and Bill Moyers, The Power of Myth (New York: Random House Inc., 1988) xiii, 23, $37,159,177-179,209$.

${ }^{34}$ The Mythology of 'Star Wars', Produced George Lucas and Bill Moyers (For the Humanities production co.: Public Broadcast Services, 2000).

${ }^{35}$ The Mythology of 'Star Wars', Produced George Lucas and Bill Moyers (For the Humanities production co.: Public Broadcast Services, 2000).
} 
which would be appealing to a large audience. The work of Campbell argues that all cultures have been creating the same basic myths throughout recorded history. ${ }^{36}$ Lucas realized the truth of this argument and set out to make his own mythic story which, according to Campbell's work, would appeal to a variety of people because these same stories have been appealing to everyone for thousands of years. Campbell argued that structurally the Ancient Greek Iliad $^{37}$ is the same as the medieval Italian Divine Comedy, ${ }^{38}$ which are both the same as Elizabethan England's Hamlet. ${ }^{39}$ By following Campbell Lucas was able to create a story that used this pattern.

Campbell outlined some 17 stages in the journey of the hero. The first begins with a call to adventure. The hero is living a normal mundane life when he receives a call to venture into the unknown. This invitation to venture into the unknown is the first stage of the mythological journey which Campbell calls the "call to adventure." Destiny, Campbell argues, has summoned the hero and transferred his spiritual center of gravity into the unknown. The "unknown" in myth could be a distant land, a forest, an underground kingdom, a secret island, a lofty mountain, or a profound dream state. The hero makes this journey of his own volition. The hero wants to accomplish this journey. The "refusal of the call" is another way in which the journey of the hero may begin. The refusal is typically born out of fear of leaving the "known" world the hero and being thrust into the unknown world of the journey. This refusal of the summons, Campbell notes, makes this adventure a negative one. Because the character does not undertake the quest of his own free will, and he is instead forced into action. Because of that forcing his

\footnotetext{
${ }^{36}$ Joseph Campbell, The Hero with a Thousand Faces (Princeton: Princeton University Press, 1973) 3.

${ }^{37}$ Joseph Campbell, The Hero with a Thousand Faces (Princeton: Princeton University Press, 1973) 257.

${ }^{38}$ Joseph Campbell, The Hero with a Thousand Faces (Princeton: Princeton University Press, 1973) 21-22.

${ }^{39}$ Joseph Campbell, The Hero with a Thousand Faces (Princeton: Princeton University Press, 1973) 122123.
} 
journey will be a negative one. ${ }^{40}$ The heroic journey models contained within Star Wars are not negative ones as both Luck and Anakin undertake their quests willingly if albeit somewhat reluctantly.

The next stage of the journey involves the appearance of supernatural aid. Once the hero has committed himself to his quest he soon finds that he encounters a magical helper. Often this person is a supernatural mentor. This magical-supernatural-helpermentor is the benign protecting power of destiny. After meeting and attaining the aid of the mentor-helper, the hero must cross the first threshold. This crossing of the first threshold occurs after the hero leaves the known limits of his world and ventures into the unknown and the dangerous realms of the journey. This threshold is usually signaled by encounters with threshold guardians at the entrance of a marginal zone. ${ }^{41}$

The next stage is referred to as the "belly of the whale." It marks the final separation from the known world of the hero, the known world of the self. When one enters this stage, he demonstrates a willingness to undergo a final metamorphosis. The belly of the whale represents for Campbell a form of rebirth in which a person is in the worldwife womb. The hero is swallowed up by the unknown. It even appears to others that he has died. What they don't know is that he has gone inward in order to be born again. $^{42}$

The next stage involves a series of trials. The hero must undergo a series of tests. This stage of the heroic journey marks the beginning of the hero transformation. These tests often come in threes and the hero must survive them in order to progress. For Campbell, the heroic journey was very much a process by which the protagonist is

\footnotetext{
${ }^{40}$ Joseph Campbell, The Hero with a Thousand Faces (Princeton: Princeton University Press, 1973) 49-68.

${ }^{41}$ Joseph Campbell, The Hero with a Thousand Faces (Princeton: Princeton University Press, 1973) 69-89.

${ }^{42}$ Joseph Campbell, The Hero with a Thousand Faces (Princeton: Princeton University Press, 1973) 90-95.
} 
transformed from what he was into the hero he was always meant to be. Each of these trials, ordeals, and tests shapes the protagonist in some way. The hero sheds aspects of his old self through these tests so as to be reformed into something new, i.e. the hero. ${ }^{43}$

After he has successfully overcome these trials, he enters the next stage in which he meets with the goddess. The meeting between the heroic figure and the goddess is the point at which the hero encounters the experience of unconditional love within the heroic journey. This meeting is often represented by the hero finding a person who is his true love. However, there are also trials associated with this stage. His next stage involves the woman as a temptress who uses lust to detract him from his spiritual journey. This stage does not necessarily have to be represented by a woman. It can be, for example, an offer of greatness such as a crown or a kingdom if the protagonist agrees to quit the quest he is on. This stage really has to do with the physical and material temptations of life that the hero must overcome. ${ }^{44}$

The stage that follows involves atonement with the father. In this stage, the hero must confront whatever holds the ultimate power in his life. The atonement-with-thefather stage is the center point of the hero's journey. The atonement with the father is above the atonement with power. The example of this stage of the heroic quest is often illustrated by William Shakespeare's Hamlet. In the play, the character Hamlet must avenge the death of his father by killing his uncle murderer who is also the king. However, in order to be a good subject of the crown Hamlet must support his uncle king. The reconciliation of these two conflicting objectives is the crux upon which the story of

\footnotetext{
${ }^{43}$ Joseph Campbell, The Hero with a Thousand Faces (Princeton: Princeton University Press, 1973) $97-$ 109.

${ }^{44}$ Joseph Campbell, The Hero with a Thousand Faces (Princeton: Princeton University Press, 1973) 109126.
} 
Hamlet is based and therefore Campbell's atonement with the father stage is most clearly illustrated here. ${ }^{45}$

Next comes the apotheosis. The world is full of opposites. In the apotheosis stage one moves beyond these polarities and enters into a state of divine knowledge, love, compassion, and bliss. Campbell is fond of using "bliss" by which he means the apothęosis. ${ }^{46}$

The next stage is the ultimate boon. The goal of the quest has been achieved. Campbell associates this stage with a kind of grace or elixir. It is the Holy Grail, the Golden Fleece, the head of Medusa that was the ultimate purpose for undertaking the quest. $^{47}$

The next stage involves the return. Having found bliss and enlightenment, the hero wants to return to the ordinary world to bestow his earned gifts unto his fellow man. The return may involve a magical flight if the hero wins the blessing of the gods and goddess and is explicitly commissioned to return to the world with some elixir for the restoration of society. In this return, the hero needs guides and assistants to bring him back to everyday life. Sometimes the hero may return from his supernatural adventure without this assistance. In either case, he must cross the return threshold. He must return with the wisdom that he gained during the journey. He must survive the impact of the world. If the hero is able to survive the impact of the world and retain the wisdom he gained during the heroic journey then he will become the master of two worlds and will

\footnotetext{
${ }^{45}$ Joseph Campbell, The Hero with a Thousand Faces (Princeton: Princeton University Press, 1973) 126149.

${ }^{46}$ Joseph Campbell, The Hero with a Thousand Faces (Princeton: Princeton University Press, 1973) 149171.

${ }^{47}$ Joseph Campbell, The Hero with a Thousand Faces (Princeton: Princeton University Press, 1973) 172192.
} 
have the freedom to move back and forth between them. This mastery will give him the freedom to live without fear of death. ${ }^{48}$

${ }^{48}$ Joseph Campbell, The Hero with a Thousand Faces (Princeton: Princeton University Press, 1973) 193243. 


\section{THE HERO'S JOURNEY IN STAR WARS}

When George Lucas was mapping out what would eventually become the saga of Star Wars he used the heroic journey described by Joseph Campbell as a road map from which his story grew. ${ }^{49}$ The Star Wars saga is broken into two different parts with two different protagonists. Episodes IV, V, and VI deal with Luke Skywalker, while episodes I, II, and III deal with Luke's father Anakin Skywalker, portrayed by Jake Lloyd and Hayden Christenson. While not all stages of the heroic journey are represented in all Star Wars movies, the two heroes Anakin and Luke Skywalker both undergo transformative journeys which shape them into heroes. Unlike his son, the journey of Anakin Skywalker transforms him into a tragic hero, and therefore the stages of Campbell's heroic journey can be seen more clearly in the stories of Luke.

George Lucas's interpretation of Joseph Campbell's heroic journey in Star Wars does place greater importance on some stages of the quest over the others. For example Lucas does not really deal with the "Woman as Temptress" stage in Luke's heroic journey. The only female presence in Luke's journey is Princess Leia who does not act as a deterrent from the quest, as a woman as temptress would according to Campbell, but is instead a driving force for Luke. ${ }^{50}$ In Luke's heroic journey Lucas does, however place

\footnotetext{
${ }^{49}$ The Mythology of 'Star Wars', Produced George Lucas and Bill Moyers (For the Humanities production Co.: Public Broadcast Services, 2000).

${ }^{50}$ Joseph Campbell, The Hero with a Thousand Faces (Princeton: Princeton University Press, 1973) 120126.
} 
a great deal of importance on Campbell's "Atonement with the Father" stage of the journey. ${ }^{51}$ It could be argued that the overlying theme of Luke's entire quest is to come to some type of atonement with his father Darth Vader.

Conversely, Lucas places a great deal of importance on the "Woman as Temptress" stage in Anakin's heroic journey. The love which develops between Queen Amidalla and Anakin Skywalker is forbidden by Jedi law. If the purpose of Anakin's heroic journey is to become the greatest Jedi in history, which is what Anakin himself claims his journey to be about, then the love Anakin feels towards Amidalla acts as a temptress away from his heroic journey. ${ }^{52}$ And so it is clear that George Lucas does place greater importance on some stages of the heroic journey Joseph Campbell describes in his work.

The Star Wars story opens with a young farm boy Luke Skywalker being raised by his aunt and uncle on the frontier. In the documentary Star Wars: A Legacy Revealed, filmmaker Peter Jackson stated that many heroes start from humble beginnings such as Dorothy Gale, Frodo Baggins, and Harry Potter. ${ }^{53}$ In Greek Myth, the hero Oedipus was raised by farmers before he underwent a quest which eventually crowned him king. ${ }^{54}$ The "call to adventure" comes from Princess Leia, portrayed by Carrie Fisher, who requires aid for her Rebellion. Luke is asked to leave the only home he has ever known and travel into the unknown world of adventure. At this stage of the story we also encounter "the refusal of the call" in which Luke states that he must instead stay on the

\footnotetext{
51 Joseph Campbell, The Hero with a Thousand Faces (Princeton: Princeton University Press, 1973) 126149.

52 Star Wars Episode II: Attach of the Clones, Dir. George Lucas (Fox Searchlight Studios, and Lucasfilm Ltd., 2004).

${ }_{53}$ Star Wars: The Legacy Revealed, Dir. Kevin Burnes (The History Channel and Lucasfilm Ltd., 2007).

${ }^{54}$ Sophocles, The Theban Plays Trans. David Grene (Chicago: University of Chicago Press, 1991).
} 
farm. This refusal is born out of self-doubt and the sense of familiar reliability Luke feels for his life on the farm. Almost immediately in the story of Star Wars does Luke encounter his "mentor" Wise Old Man in the form of Obi-wan Kenobi. Kenobi introduces Luke the "Force." $" 55$

Part religion, part karma, part metaphysics, the Force is described as a kind of life energy upon which the galaxy relies to function. Jedi knights, of whom Kenobi is one of the last, have the ability to use the Force in a way that serves their needs. Obi-wan Kenobi offers to train young Luke in the ways of the Force to become a Jedi knight. During this stage Joseph Campbell notes that a "magical item" is often passed to the fledgling hero. This item will aid the hero throughout his journey. ${ }^{56}$ In the medieval tales of King Arthur, it is during this stage that the Lady of the Lake gives Excalibur to aid the king in his own heroic journey. ${ }^{57}$ Likewise Kenobi passes to Luke his father's light saber sword which becomes a magical totem. The heroic journey of Luke is next aided not by magic but instead through the more practical helper Han Solo. In the heroic quest, Han Solo represents the practical aid needed by the hero to accomplish the goals of the quest.

Han Solo, portrayed by Harrison Ford, offsets the mystical Obi-wan Kenobi and relies on lazar guns, navigational maps, and other technologies to achieve his goals. While Obi-wan represents the mystical presence of the Star Wars universe, Solo represents the more practical technological aspects. The Solo character anchors Luke to

\footnotetext{
${ }^{55}$ Star Wars Episode IV: A New Hope, Dir. George Lucas (Fox Searchlight Studios and Lucasfilm Ltd., 1977).

${ }^{56}$ Star Wars Episode IV: A New Hope, Dir. George Lucas (Fox Searchlight Studios and Lucasfilm Ltd., 1977).

${ }^{57}$ Thomas Malory, Le Morte D'Arthur: King Arthur and of his Noble knights of the Round Table, (London: Simon \& Brown Publishers, 2009).
} 
the more practical necessities needed to achieve the goals of the journey. Instead of "use the force Luke" which are lessons Obi-wan teaches, Han Solo concerns himself with the more mechanical/practical "fix the ship so we can escape" aspects of the story. ${ }^{58}$

While the smaller goals of each Star Wars film change from movie to movie, the overall goal of the first three installments is to overthrow the oppressive Empire. In order for Luke to enter this fight, he must first escape his home planet and join the Rebellion. Crossing the first threshold for Luke involves avoiding capture by the Empire long enough to join the resistance and impart to them information that will help facilitate the destruction of the Empire. Traveling to a place he believes houses the Rebellion (Princess Leia's home planet Alderan), Luke Skywalker instead encounters the Death Star, a large moon-sized space station, which he is drawn into. The Death Star is Lucas's version of the whale which the hero must enter in Campbell's stage of the heroic journey. ${ }^{59}$ Through the next two movies, Luke experiences a series of trials and tests which shape mold and hone him into the heroic figure he will eventually become. To Joseph Campbell, the heroic journey is designed to make the protagonist, who is not a hero in the beginning of the tale, and form him into something new, i.e. the heroic figure at the end of the story. The tests and trials Luke experiences throughout episodes IV, V, and VI of the Star Wars saga shape him into that hero. To the Greeks the heroes were the demigods of legends, but to the world of Star Wars the heroic figure is the Jedi knight. And that is what Star Wars does: it changes a farm boy into a Jedi knight. As the heroic journey of Luke continues, he eventually encounters unconditional love by discovering Princess Leia is his twin sister. There are many twin births in mythology. Artemis and

\footnotetext{
${ }^{58}$ Star Wars Episode IV: A New Hope, Dir. George Lucas (Fox Searchlight Studios and Lucasfilm Ltd., 1977).

${ }^{59}$ Joseph Campbell, The Hero with a Thousand Faces (Princeton: Princeton University Press, 1973) 90-95.
} 
Apollo, Castor and Pollux, Romulus and Remus are just a few examples of such pairs which are deemed mythically significant. ${ }^{60}$ During one of his transformative trials, Luke discovers his father is the villain Darth Vader, played by David Prowse. ${ }^{61}$ Although Luke is confronted with the truth of his parentage in Episode V, it is not until Episode VI that Luke experiences atonement when he refuses to kill his father Darth Vader. Vader in turn saves the life of his son by sacrificing himself. ${ }^{62}$

With both the Emperor and Darth Vader killed, and the Death Star destroyed, the Rebellion has accomplished the long sought goal of eliminating the Empire. And although the rest of the galaxy has reached apotheosis due to the downfall of the Empire and the return of freedoms, the final boon is met with a mixture of sadness and joy on the part of Luke. The quest now completed, he has become a full Jedi knight and is the hero he was destined to become. And while Lucas ends the story of Luke's heroic journey at this point, the audience is left with a sense that the galaxy has now become the environment the Rebels had been fighting for throughout the Star Wars saga. The plot of Star Wars is what allowed Lucas to introduce the heroic journey to the audiences of his films.

The hero in most cultures is a larger-than-life figure who is perched a rung above the "common man." A3 As such, the hero must prove himself to be something more than just another person. The heroic journey is designed to be a series of unpleasant experiences which all force the protagonist to become that something more. The Woman

\footnotetext{
${ }^{60}$ Edith Hamilton, Mythology (New York: Little, Brown and Company Publishers, 1998).

${ }^{61}$ Star Wars Episode V: The Empire Strikes Back, Dir. Irvin Kershner (Fox Searchlight Studios and Lucasfilm Ltd., 1980).

${ }^{62}$ Star Wars Episode VI: Return of the Jedi, Dir. Richard Marquand (Fox Searchlight Studios and Lucasfilm Ltd., 1983).

${ }^{63}$ Joseph Campbell, The Hero with a Thousand Faces (Princeton: Princeton University Press, 1973) 249.
} 
as Temptress stage of Campbell's heroic journey is designed to tempt the protagonist away from the quest which is forming him into a heroic figure and instead succumb and peruse the desires of the flesh. In The Hero with a Thousand Faces Campbell describes this stage of the heroic journey as:

The mystical marriage with the queen goddess of the world represents the hero's total mastery of life; for the woman is life, the hero its knower and master. And the testing of the hero, which were preliminary to his ultimate experience and deed, were symbolical of those crises of realization by means of which his consciousness came to be amplified and made capable of enduring the full possession of the mother-destroyer, his inevitable bride. $^{64}$

Campbell argues that in order for the hero to reach his end he must first overcome the temptations the woman as temptress presents. It is a very natural and carnal entity she represents, one in which most common men would indulge, but which the hero must overcome in order to continue his heroic journey.

In Greek mythology, an example of woman as temptress can be found in the legend of Odysseus. On his way home from the Trojan War, Odysseus stops on the island of the witch Circe for a number of years before continuing on his journey to Ithaca. In this myth, Circe represents the temptation to not return home, not fulfill his quest and simply stay on the island with Circe. It is, in a way, the easy choice to forgo the rest of the arduous journey and simply remain stationary and carnally fulfilled. ${ }^{65}$ In Star Wars Padme, played by Natalie Portman, is the woman as temptress to Anakin Skywalker. ${ }^{66}$

It is revealed in Episode II that a Jedi knight is not allowed to marry or to take a lover. To do so would introduce an element of greed in the Jedi's life, the argument

\footnotetext{
${ }^{64}$ Joseph Campbell, The Hero with a Thousand Faces (Princeton: Princeton University Press, 1973) 120.

${ }^{65}$ Homer, The Odyssey, Trans. W.H.D. Rouse (New York: Penguin Books Group, 1937).

${ }^{66}$ Padme embodies the temptress in Episodes II and III, but this role can be seen most prominently in Star Wars Episode III: Revenge of the Sith, Dir. George Lucas (Fox Searchlight Studios and Lucasfilm Ltd., 2005).
} 
being a Jedi would choose his love over the demands of the greater good. It would cause the Jedi to lose focus and therefore become ineffectual in his duties. Anakin is tempted by Padme in Episode II and then faces the choice either to succumb to that temptation, thereby retarding his Jedi abilities, or ignore the temptation and continue on his journey to become a powerful Jedi. Anakin chooses to give in to his feelings and takes Padme as his wife. ${ }^{67}$ The full effects of this act are seen in Episode III when Anakin turns to the Dark Side in an attempt to save Padme's life, which disastrously becomes the cause of her fatality. Anakin was unable to overcome the temptress and became the cause of the very event he was trying to prevent, i.e., the death of Padme. For these reasons Anakin Skywalker is a tragic hero.

${ }^{67}$ Star Wars Episode II: Attach of the Clones, Dir. George Lucas (Fox Searchlight Studios and Lucasfilm Ltd., 2002). 


\section{VLADIMIR PROPP AND THE STRUCTURE OF THE FOLK TALE}

From 1910 to 1930 , a literary school known as the Russian Formalists revolutionized literary criticism by separating poetic language from literature. Vladimir Propp was among these scholars. Reducing fairy tales to a series of actions performed by the protagonist in each story, Propp argued that all fairy tales were constructed of certain plot elements. He called these functions. After studying hundreds of folk tales, he came up with a list of 31 basic functions upon which all fairy tales were based.

These 31 elements have to do with the functions (narratemes) that the protagonist in a story must encounter. The first seven steps have to do with the introduction to the story. They introduce most of the characters, and set the scene for the adventure that is to follow. The first stage is absentation. Absentation is where someone in the story is missing. The next stage is the interdiction. Interdiction is where the hero is warned about some action. The next stage occurs when the hero ignores the interdiction, called the violation of the interdiction. The villain now makes an active attempt at reconnaissance. He searches for something valuable or tries to actively capture someone. The actual violation of the interdiction occurs when the villain receives a payoff and acquires some form of information about the hero or victim. Trickery is involved as the villain attempts to deceive the victim. The seventh stage involves complicity in which 
the trickery of the villain now works and the hero naively acts in a way that helps the villain in some way.

The second sphere of the morphology of the folk tale has to do with the body of the story. These eight stages identify a need. There are two parts to this stage, either or both of which may appear in the story. In the first stage, the villain causes some kind of harm. In the second stage, a sense of lacking is identified. Something is identified as lost and in the next stage, the hero discovers that something is missing. He then makes a move to counteract this situation. Finally the hero leaves on a mission.

In the third sphere of the story, the hero tries to find a way to solve the problem. This solution comes in the form of a magical agent from a donor. Here the hero is challenged to prove his heroic qualities. He takes on the task and gains magical assistance in the form of an object. The hero and the villain enter into combat and the hero is wounded. However, the villain is defeated and the initial misfortune is resolved.

In the fourth sphere, the hero sets out for home. In the process, he is pursued. He evades this situation and returns home unrecognized. Another person claims to be the hero. The hero is given a difficult task to do and meets that challenge. The false hero is recognized and exposed. The hero is not transformed and he is given a new appearance. The villain is punished and the hero marries a princess and ascends the throne.

When Hollywood began to make Westerns, they used this concept of the various stages of storytelling. However they modified these stages in many ways. They found out that they did not need all 31 stages so they, for example, cast the role of the donor as the side-kick. The Hollywood Western based itself on the fairy-tale style because of its simplicity and because it was a style of storytelling with which audiences were already 
familiar. Hollywood consciously took many of the overriding themes of fairytales, such as good vs. evil, and placed these elements in the emerging Western genre. Through experimentation, Hollywood eventually learned that not all 31 stages of a fairytale were needed which simplified the Western story. Star Wars is an example of a sci-fi Western story. 


\section{PROPPS' INFLUENCE ON THE WORK OF JOSEPH CAMPBELL}

George Lucas based much of Star Wars on what Joseph Campbell termed the "heroic journey" which was described in Campbell's book hero with a Thousand Faces. The heroic journey consists of 16 stages that a heroic figure will go through in the course of a mythological quest story. Because the quest story is a common element in most cultures, Campbell argued that all quest stories contain these same 16 stages.

What is not well documented is how much of Campbell's work was influenced by other writers. It has already been discussed how the writings of both Bastian and Jung became a part of Campbell's work but the theories of Vladamir Propp can also be found within both The Hero with a Thousand Faces and by extension the Star Wars movie collection. Other scholars have noted how similar the work of both Campbell and Propp truly are. In his book The Fairy Tale: The Magic Mirror of the Imagination, Author Steven Swann Jones talked about how both Propp and Campbell worked to decipher the structure inherent in myth and fairytale stories. Jones says in his book: 
Beyond the inclusion of the fantastic, there are a number of typical, if not necessary, characteristics of this genre \{fairytale\}. For example, various scholars, such as Lüthi, Campbell, Bettelheim, and Vladimir Propp have identified the confronting and resolving of a problem, frequently by the undertaking of a quest, as essential to the fairy tale... Some scholars, for example Propp and Campbell, have attempted to define more specifically the elements and goals of the quest in the fairy tale. For example, in Morphology of the Folktale (by which Propp meant the fairy tale or wonder tale), Propp attempts to identify a sequential pattern of 31 elements of the fairy tale's plot structure, some of which refer to the undertaking of a quest... Joseph Campbell, in The Hero with a Thousand Faces, also identifies a quest pattern as typifying fairy tales, but he does not try to define the fairy tale genera by it. Rather, he links the appearance of this pattern in some fairy tales with its use in other forms of literature and art-for example, myths, religious narratives, legends, and ritual ceremonies... ${ }^{68}$

The work of Propp and Campbell are often linked together because of the striking similarities between the two. First published in 1928, Propp's Morphology of the Folktale focused on Russian folklore and the similarities which exist within these different stories. The stages Propp described in his work are, arguably, what could have had the most influence on the writings of Campbell who later influenced Lucas. The stages of Joseph Campbell's heroic journey will be discussed in greater detail in a later section with regard to its influence on Star Wars; however it is important to see the similarities between Propp and Campbell.

It is important to understand the similarities between the works of Propp and Campbell because many of the specific plot elements which occur in Star Wars are described in more detail within the work of Propp. The heroic journey described in Campbell's work is basically a distilled version of the fairytale Propp described in Morphology of the Folktale. For example, one of Campbell's stages of the heroic journey is "Refusal of the Call" to adventure. Campbell argues that a hero will at first refuse to

\footnotetext{
${ }^{68}$ Steven Swann, The Fairy Tale: The Magic Mirror of the Imagination (London: Routledge Puslighing, 2003) 14-16.
} 
undertake the heroic journey. Likewise, because of Campbell, George Lucas' character Luke Skywalker refuses the call to adventure given by Obi-wan, instead choosing to stay on the farm. However, Propp goes further than does Campbell by describing how a character can change their mind and accept the call. One of Propp's stages of a fairytale is "Villainy: The Villain causes harm or injury to a member of a family." And we see in Star Wars how the villain of the story causes harm to Luke Skywalker's family by killing his aunt and uncle. Ultimately it is that action which causes Luke to undertake the heroic journey. Likewise Propp describes how the heroic character is often branded or marked, something that is not discussed in the work of Campbell. Both Star Wars heroes Luke and Anakin are branded through the loss of their hands. So by better understanding Propp, we better understand Star Wars. Again, there is no direct proof that Campbell ever read the work of Propp. However, the work of Vladimir Propp predates the work of Campbell by three decades and was very influential to the field of mythological and literary study as a whole so it is worth noting these similarities between Propp and Campbell. The importance of Vladimir Propp's work to many fields have been researched by scholars such as Ariadna and Richard Martin who collected, translated and published posthumously some of Propp's unknown work in Theory and History of Folklore. In the introduction, editor Anatoly Liberman talks about the influence Propp had on other scholars in different fields. He states: 
If in France Propp became known through \{anthropologist Claude\} LèviStrauss's critique, in the United States it was \{folklorist Alan\} Dundes who made Propp famous. The terms of the acceptance and dissemination of Propp's heritage were also determined by these two scholars. The most active French structuralists (Roland Barthes, Algirdas Greimas, Tzvetan Todorov, Claude Bremond) discussed Morphology in terms of semiotics and, following Lèvi-Strauss's cue, kept improving Propp's scheme, whereas Dundes and those who learned about Propp from him were interested in the practical application of the new method, rather than in criticism of Propp's epistemological foundations. ${ }^{69}$

It is worth noting that Alan Dundes was a critic of the work of Joseph Campbell. Both Dundes and Campbell were publically critical of each other's work and methods in regards to the structure and specific contents of myth stories. When traveling to a local bookstore and discovering that all material pertaining to the study of folklore had been placed under the heading "Joseph Campbell," Dundes remarked "I remember being almost relieved that at least none of my books were to be found in that section.".70

David Kudler, of the Joseph Campbell Foundation wrote to me personally and stated in an email: "I've looked through all of the material I have-all of Campbell's published and most of his unpublished work--and was rather surprised to find no reference to Vladimir Propp or his work. I would be shocked if Campbell hadn't read Morphology of the Folk Tale, since it was very much in his area of interest and came out while Campbell was a graduate student in Paris." ${ }^{, 71}$ Regardless of whether Joseph Campbell ever intentionally studied Vladimir Propp, the work of Propp was highly influential to the academic community as a whole. As was previously stated, Campbell was studying in Paris when the work of Popp was first published; and it was during this

\footnotetext{
${ }^{69}$ Vladimir Propp, Theory and History of Folklore Trans. Ariadna Martin and Richard Martin (Minneapolis: University of Minnesota Press., 1984) X.

${ }^{70}$ Alan Dundes, "Folkloristics in the Twenty-First Century," Journal of American Folklore (Chicago: University of Illinois Press. 2005) Issue No. 470, 385-408.

${ }^{71}$ This was a personal correspondence I had with the Joseph Campbell Foundation while doing research for this thesis. The full copy of the email which contains this quote can be found in the reference section of this work.
} 
same time that Claude Lèvi-Strauss was first reading and promoting Morphology of the Folktale. Campbell certainly would have been aware of Propp's work, and there are striking similarities between the two works.

\begin{tabular}{|c|c|c|}
\hline \multicolumn{3}{|c|}{ Vladamir Propp's Influence on the Joseph Campbell's heroic journey } \\
\hline $\begin{array}{|lr|}\text { Vladamir } & \text { Propp } \\
\text { Morphology of the } \\
\text { Folktale. }\end{array}$ & $\begin{array}{l}\text { Joseph Campbell Hero } \\
\text { with a Thousand Faces }\end{array}$ & Analysis \\
\hline $\begin{array}{l}\text { l.Absentation: One of } \\
\text { the members of a } \\
\text { family absents himself } \\
\text { from home. }\end{array}$ & 1. Call to adventure & $\begin{array}{l}\text { Propp and Campbell agree that in a } \\
\text { journey story (either fairytale of } \\
\text { mythical quest) the protagonist is } \\
\text { called away from his "normal" lives and } \\
\text { pulled into the realm of adventure. }\end{array}$ \\
\hline $\begin{array}{l}\text { Il.Interdiction: } \\
\text { interdiction } \\
\text { addressed to the } \\
\text { hero. }^{72}\end{array}$ & & $\begin{array}{l}\text { Propp mostly focused on Russian } \\
\text { fairytales which often entail a character } \\
\text { summed to a palace where he is given } \\
\text { a royal decree thereby forcing him into } \\
\text { the adventure. }\end{array}$ \\
\hline
\end{tabular}

A heroic character is often a person who is seemingly normal. Dorothy Gale from The Wizard of $\mathrm{Oz}$ or Frodo Baggins from Lord of the Rings are just two examples of how the protagonist of a heroic tale often begin the story as a very non-assuming character who do not think of themselves as "special" or "different" from the other members of their culture (whether Kansas farmers or Shire Hobbits).

\footnotetext{
${ }^{72}$ Vladimir Propp, Morphology of the Folktale, Trans. Laurence Scott (Austin: University of Texas Press, 2008) 26.
} 


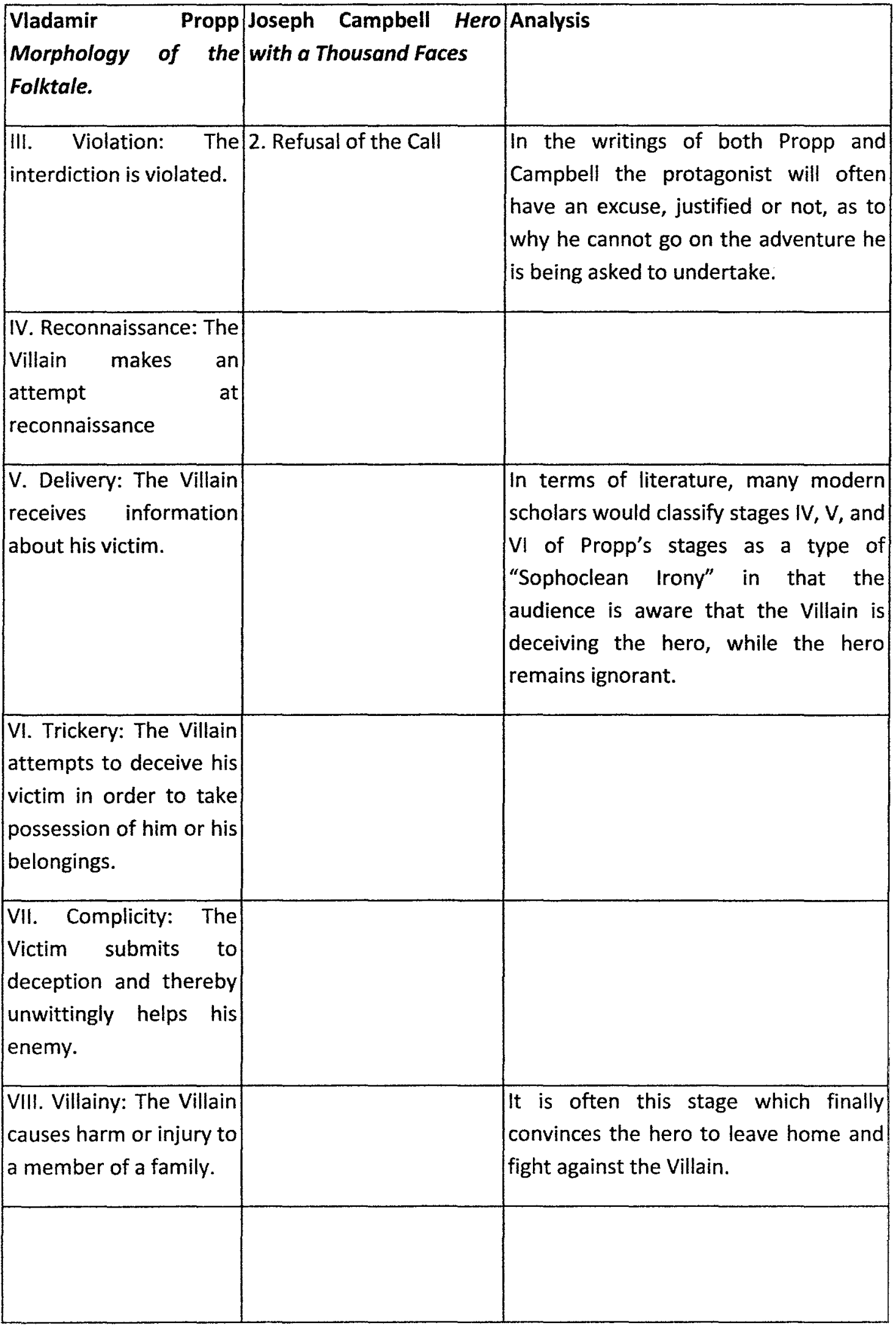




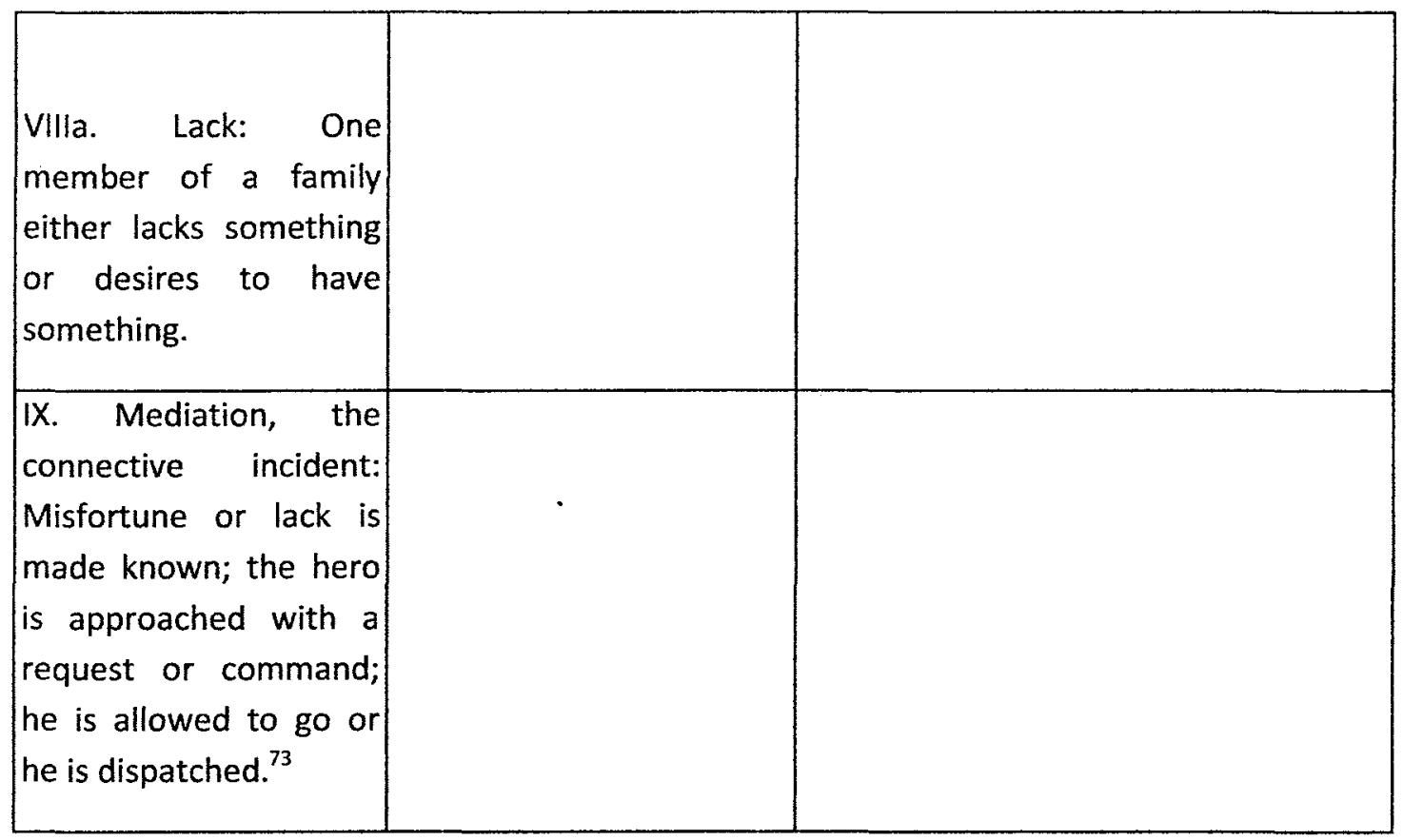

Many literary scholars would label some stages Propp outlines in his analysis of fairytales "exposition" in stories. However, these stages are valid because many of the myth and fairytale stories do contain these exposition stages Propp lays out. Joseph Campbell does not fully illustrate many of these exposition stages in his form of the heroic journey because most of the writings of Campbell focus on the heroic protagonist instead of the Villain, whereas Propp spends a lot of time illustrating the moves and motivations of the antagonist character. Propp notes that in many fairytales the heroic character is forced into the adventure by the villain. The protagonist is given little or no choice but to venture out away from his home. Both Campbell and Propp agree that the heroic character will often be forced into the adventure. The reluctance of the character to undertake the adventure, both Propp and Campbell agree, is the hero's reluctance to

\footnotetext{
${ }^{73}$ Vladimir Propp, Morphology of the Folktale, Trans. Laurence Scott (Austin: University of Texas Press, 2008) 27-38.
} 
leave the life they have known and venture into the unknown. So emphasis on certain stages rather than others depends on narrative point of view.

\begin{tabular}{|l|l|l|}
\hline $\begin{array}{l}\text { Vladamir Propp } \\
\text { Morphology of the } \\
\text { Folktale. }\end{array}$ & $\begin{array}{l}\text { woseph Campbell Hero } \\
\text { with a Thousand Faces }\end{array}$ & Analysis \\
\hline $\begin{array}{l}\text { X. Beginning } \\
\text { counteraction: The } \\
\text { Seeker agrees to or } \\
\text { decides } \begin{array}{l}\text { First Threshold } \\
\text { counteraction. upon }\end{array}\end{array}$ & $\begin{array}{l}\text { Findertake the adventure, they fully } \\
\text { commit themselves thereby leaving } \\
\text { behind their "normal" lives and } \\
\text { cross into the unknown. }\end{array}$ \\
$\begin{array}{l}\text { XI. Departure: The } \\
\text { hero leaves home. }\end{array}$ & & $\begin{array}{l}\text { Both Propp and Campbell agree that } \\
\text { the beginning of the adventure is } \\
\text { difficult for the protagonist }\end{array}$ \\
$\begin{array}{l}\text { XII. The first function } \\
\text { of the donor: The hero } \\
\text { is tested, interrogated, } \\
\text { attacked, etc., which } \\
\text { prepares the way for } \\
\text { his receiving either a } \\
\text { magical agent or } \\
\text { helper. }\end{array}$ & & \\
\hline
\end{tabular}

Joseph Campbell argues in Hero with a Thousand Faces that the world of adventure is separate from the "every-day-normal" existence of the common man. ${ }^{75}$ When the protagonist commits himself to the journey there is a breaking away from the common-man existence as the protagonist enters this new world of the adventure story. Vladamir Propp argues in his book Morphology of the Folktale that the protagonist almost immediately begins to be tested by this world of adventure. These tests, Propp

\footnotetext{
${ }^{74}$ Vladimir Propp, Morphology of the Folktale, Trans. Laurence Scott (Austin: University of Texas Press, 2008) 38-42.

${ }^{75}$ Joseph Campbell, The Hero with a Thousand Faces (Princeton: Princeton University Press, 1973) 77.
} 
argues, are designed to evaluate the protagonist's worthiness. Only a worthy person will survive the tests and obstacles of the adventure world and become a hero. ${ }^{76}$

\begin{tabular}{|l|l|l|}
\hline $\begin{array}{l}\text { Vladamir Propp } \\
\text { Morphology of the } \\
\text { Folktale. }\end{array}$ & $\begin{array}{l}\text { Joseph Campbell Hero } \\
\text { with a Thousand Faces }\end{array}$ & Analysis \\
\hline $\begin{array}{l}\text { XIII. The hero's } \\
\text { reaction: The hero } \\
\text { reacts to the actions of } \\
\text { the future donor. }\end{array}$ & 3. Supernatural Aid & $\begin{array}{l}\text { A "helper" character enters the } \\
\text { adventure story who aids the hero. } \\
\text { This helper is usually in the form of } \\
\text { a mentor or some other wise agent } \\
\text { who is familiar and comfortable } \\
\text { within the adventure world. }\end{array}$ \\
\hline $\begin{array}{l}\text { XIV. Provision or } \\
\text { receipt of a Magical } \\
\text { Agent: The hero } \\
\text { acquires the use of a } \\
\text { Magical Agent. }\end{array}$ & $\begin{array}{l}\text { Both Propp and Campbell agree that } \\
\text { the heroic character is unable to } \\
\text { complete the story without some } \\
\text { type of aid. This aid is usually given } \\
\text { to the heroic character in the form of } \\
\text { a magical devise. }\end{array}$ \\
\hline
\end{tabular}

It is important to remember that fairytales and heroic journeys do not operate on the same rules as the "normal" mundane world. They are separate and different and therefore operate differently. The forces which are mounted against the protagonist in any adventure story are in some way magical. The villain in a fairytale or heroic journey is an evil wizard or king and so the weapons the protagonist must use to combat these forces must also be magical. This weapon is bestowed upon the protagonist via a helper character who also gives aid in the form of guidance. ${ }^{78}$ Propp labeled this character a magical agent, Campbell called him a mentor but the role this character plays is vital to

\footnotetext{
${ }^{76}$ Vladimir Propp, Morphology of the Folktale, Trans. Laurence Scott (Austin: University of Texas Press, 2008) 39-42. Propp describes a total of ten different scenarios in which a protagonist is tested as soon as they cross the threshold into the world of adventure. Propp, for example, stated on page 39: "A witch gives a girl household chores. Forest knights propose that the hero serve them for three years... A dragon suggests the raising of a heavy stone. Sometimes this request is written on the stone, and other times brothers, upon finding a big stone, try to lift it themselves..."

${ }^{77}$ Vladimir Propp, Morphology of the Folktale, Trans. Laurence Scott (Austin: University of Texas Press, 2008) 42-50.

${ }^{78}$ Joseph Campbell, The Hero with a Thousand Faces (Princeton: Princeton University Press, 1973) 69.
} 
the protagonist because here is a character that has answers. Instead of blindly stumbling through the rest of the adventure, the protagonist finds a guide in the form of this magical agent/mentor. In Campbell's version of the adventure story the protagonist receives this aid sooner than he does in the writings of Propp but the concepts and reasons behind this aid are the same in both.

\begin{tabular}{|c|c|c|}
\hline $\begin{array}{l}\text { Vladamir Propp } \\
\text { Morphology of the } \\
\text { Folktale. }\end{array}$ & $\begin{array}{l}\text { Joseph Campbell Hero } \\
\text { with a Thousand Faces }\end{array}$ & Analysis \\
\hline $\begin{array}{l}\text { XV. } \\
\text { transference between } \\
\text { two kingdoms, } \\
\text { guidance: The hero is } \\
\text { transferred, delivered, } \\
\text { or led to the } \\
\text { whereabouts of an } \\
\text { object of search. }\end{array}$ & $\begin{array}{l}5 . \text { The Belly of the } \\
\text { Whale }\end{array}$ & $\begin{array}{l}\text { The protagonist's location is } \\
\text { physically shifted to something new } \\
\text { and/or dangerous. This is a } \\
\text { metaphor for the shifting which is } \\
\text { occurring within the protagonist } \\
\text { himself. }\end{array}$ \\
\hline
\end{tabular}

Both Vladamir Propp and Joseph Campbell argue that the adventure tale is designed to shape the protagonist into something other than what they were before they began the story. The adventure and normal world are different the hero must adapt and recondition himself to his new world. ${ }^{80}$ Through the course of the story the character stops being the person they were in the "normal" world and starts to become more like the helper magical/mentor character who is, as stated earlier, already comfortable within the adventure world. The change in location (whether a new far-off kingdom or the belly of a whale) is in fact a shift in the protagonist's personality as he begins to adapt to this new world of adventure.

\footnotetext{
${ }^{79}$ Vladimir Propp, Morphology of the Folktale, Trans. Laurence Scott (Austin: University of Texas Press, 2008) 50-51.

${ }^{80}$ Both Propp and Campbell describe the world of adventure as something "other." Campbell stated: "The regions of the unknown (desert, jungle, deep sea, alien land, etc.) are free fileds for the projection of unconscious content." In other words, the adventure world is so different from the world the protagonist was accustomed to, they must either adapt or they will fail their quest. Joseph Campbell, The Hero with a Thousand Faces (Princeton: Princeton University Press, 1977) 79.
} 


\begin{tabular}{|l|l|l|}
\hline $\begin{array}{l}\text { Vladamir Propp } \\
\text { Morphology of the } \\
\text { Folktale. }\end{array}$ & $\begin{array}{l}\text { Joseph Campbell Hero } \\
\text { with a Thousand Faces }\end{array}$ & Analysis \\
\hline $\begin{array}{l}\text { XVI. Struggle: The } \\
\text { hero and the villain } \\
\text { join in direct combat. }\end{array}$ & 6. The Road of Trials & $\begin{array}{l}\text { Both Propp and Campbell } \\
\text { acknowledge that the adventure } \\
\text { story is fraught with dangers which } \\
\text { are obstacles the hero must endure in } \\
\text { order to move through the story and } \\
\text { become a hero. }\end{array}$ \\
\hline $\begin{array}{l}\text { XVII. Branding, } \\
\text { Marking: The hero is } \\
\text { branded. }\end{array}$ & $\begin{array}{l}\text { 81 } \\
\text { The brand is typically seen as being } \\
\text { both a symbol of the undertaken } \\
\text { adventure and as a mark that the } \\
\text { adventure world is so much more } \\
\text { dangerous and different from the } \\
\text { normal world. }\end{array}$ \\
\hline
\end{tabular}

The adventure stories that both Propp and Campbell discuss are a series of obstacles designed to turn the protagonist character from an ordinary person of the normal world into the extraordinary conqueror of the adventure world. Not all members of society are fit to become a hero, which is why heroic characters are so revered in culture: because of their extraordinary accomplishments as well as the rarity of such heroes. Because the adventure world is so fraught with dangerous obstacles for the hero to overcome he is marked in some painful way (the loss of a hand or a huge scar are a few examples). These marks are physical signs of the hero's commitment to complete the adventure story. ${ }^{82}$

\footnotetext{
${ }^{81}$ Vladimir Propp, Morphology of the Folktale, Trans. Laurence Scott (Austin: University of Texas Press, 2008) 51-52.

${ }^{82}$ Both Propp and Campbell argue that the hero of a fairytale/journey story will be marked in some way because the adventure is by design fraught with danger. Propp states: "The hero receives a wound during the skirmish. A princess awakens him before the fight by making a small wound in his cheek with a knife. A princess brands the hero on the forehead with a signet ring..." Whatever the mark, the hero is unable to traverse the world of adventure unscathed. Vladimir Propp, Morphology of the Folktale, Trans. Laurence Scott (Austin: University of Texas Press, 2008) 52.
} 


\begin{tabular}{|l|l|l|}
\hline $\begin{array}{l}\text { Vladamir Propp } \\
\text { Morphology of the } \\
\text { Folktale. }\end{array}$ & $\begin{array}{l}\text { Joseph Campbell Hero } \\
\text { with a Thousand Faces }\end{array}$ & Analysis \\
\hline $\begin{array}{l}\text { XVIII. Victory: The } \\
\text { Villain is defeated. }\end{array}$ & 10. The Ultimate Boon & $\begin{array}{l}\text { The goal of the protagonist is } \\
\text { realized. Whatever reason the } \\
\text { adventure was first begun comes to } \\
\text { fruition. }\end{array}$ \\
\hline $\begin{array}{l}\text { XIX. Liquidation: } \\
\text { The initial misfortune } \\
\text { or lack is liquidated. }\end{array}$ & & \\
\hline
\end{tabular}

Throughout the adventure story the character has evolved into something other than what he was at the outset of the story. The person who began the adventure could not accomplish whatever goal was set by the story (for example overthrowing a king or: killing a dragon). The adventure story, then, is designed to make a character that is able to accomplish the goal. Only because the character has undergone all other stages of the adventure story is he able to achieve victory and obtain the ultimate boon. Both Propp and Campbell agree that the adventure story contains the achievement of some goal. If the hero dies or is otherwise defeated in the achievement of this goal then he is a tragic hero. Either way the adventure story has some type of resolution.

\begin{tabular}{|l|l|l|}
\hline $\begin{array}{l}\text { Vladamir Propp } \\
\text { Morphology of the } \\
\text { Folktale. }\end{array}$ & $\begin{array}{l}\text { Joseph Campbell Hero } \\
\text { with a Thousand Faces }\end{array}$ & Analysis \\
\hline $\begin{array}{l}\text { XX. Return: The hero } \\
\text { returns. }\end{array}$ & $\begin{array}{l}\text { 13. The Crossing of the } \\
\text { Return Threshold }\end{array}$ & $\begin{array}{l}\text { The protagonist, now a hero because } \\
\text { of his victory, sets out to return to } \\
\text { the normal world he left behind at } \\
\text { the beginning of story. }\end{array}$ \\
\hline
\end{tabular}

The world of adventure is seen as special because of its radical difference between it and the world of the norm. Because of its special nature a hero is not allowed

\footnotetext{
${ }^{83}$ Vladimir Propp, Morphology of the Folktale, Trans. Laurence Scott (Austin: University of Texas Press, 2008) 53-55.

${ }^{84}$ Vladimir Propp, Morphology of the Folktale, Trans. Laurence Scott (Austin: University of Texas Press, 2008) 55-56.
} 
to stay in the adventure world indefinitely. A person, heroic or otherwise, is unable to be on an unending quest/journey/adventure with no downtime. Additionally, an adventure tale is started for a reason. Some goal must be accomplished, so if that goal is never realized than the protagonist has failed in his mission and cannot become a hero.

\begin{tabular}{|l|l|l|}
\hline $\begin{array}{l}\text { Vladamir Propp } \\
\text { Morphology of the } \\
\text { Folktale. }\end{array}$ & $\begin{array}{l}\text { Joseph Campbell Hero } \\
\text { with a Thousand Faces }\end{array}$ & Analysis \\
\hline $\begin{array}{l}\text { XXI. Pursuit, chase: } \\
\text { The hero is pursued. }\end{array}$ & 11. Magical Flight & $\begin{array}{l}\text { Just as the protagonist had to break } \\
\text { away from his normal world into the } \\
\text { world of adventure, so too does he } \\
\text { have to break away again. }\end{array}$ \\
\hline
\end{tabular}

Because the adventure and normal worlds are so separate, crossing between the two is always a complicated process. Heroes such as Odysseus spend a complete quest simply trying to get back home. ${ }^{86}$ Remember that everything about the world of adventure is different and magical when compared to the rest of the normal world. The villain antagonist, the hero protagonist is pitted against is magical as is the weapon and aid he uses to defeat the antagonist. So too, then, is the return from the magical adventure world back to the normal. ${ }^{87}$

\footnotetext{
${ }^{85}$ Vladimir Propp, Morphology of the Folktale, Trans. Laurence Scott (Austin: University of Texas Press, 2008) 56-57.

${ }^{86}$ Homer, The Odyssey Trans. W.H.D Rouse (New York: Penguin Books Group, 1937).

${ }^{87}$ Both Propp and Campbell argue that in a fairytale/journey story it would not be fitting for a heroic character to simply walk back into the village he left. Such a return would not be spectacular, and therefore un-heroic. Campbell even argues that there are two different scenarios for the return of the hero back to the normal world. He states: "If the hero in his triumph wins the blessing of the goddess or the god and is then explicitly commissioned to return to the world with some elixir for the restoration of society, the final stage of his adventure is supported by all the powers of his supernatural patron. On the other hand, if the trophy has been attained against the opposition of its guardian, or if the hero's wish to return to the world has been resented by the gods or demons, then the last stage of the mythological round becomes a lively, often comical pursuit. This flight may be complicated by marvels of magical obstruction and evasion." So either way the hero will make a grand entrance when he returns from the world of adventure. Joseph Campbell, The Hero with a Thousand Faces (Princeton: Princeton University Press, 1973) 196-197.
} 


\begin{tabular}{|c|c|c|}
\hline \begin{tabular}{|lr} 
Vladamir & Propp \\
Morphology of the \\
Folktale.
\end{tabular} & $\begin{array}{l}\text { Joseph Campbell Hero } \\
\text { with a Thousand Faces }\end{array}$ & Analysis \\
\hline $\begin{array}{l}\text { XXII. Rescue: Rescue } \\
\text { of the hero from } \\
\text { pursuit. }\end{array}$ & 12. Rescue from without & $\begin{array}{l}\text { The hero is aided by his allies as he } \\
\text { journeys from the adventure world } \\
\text { back home. }\end{array}$ \\
\hline $\begin{array}{l}\text { XXIII. Unrecognized } \\
\text { arrival: The hero, } \\
\text { unrecognized, arrives } \\
\text { home or in another } \\
\text { country. }\end{array}$ & & $\begin{array}{l}\text { Often the adventure has changed the } \\
\text { hero so much that he is } \\
\text { unrecognized when he returns. } \\
\text { Many years may also have passed } \\
\text { since the hero first left home. }\end{array}$ \\
\hline $\begin{array}{ll}\text { XXIV. } & \text { Unfounded } \\
\text { claims: } & \text { A false hero } \\
\text { presents } & \text { unfounded } \\
\text { claims. } & \\
\end{array}$ & & . \\
\hline $\begin{array}{l}\text { XXV. Difficult task: } \\
\text { A difficult task is } \\
\text { proposed to the hero. }\end{array}$ & & \\
\hline $\begin{array}{l}\text { XXVI. Solution: The } \\
\text { task is resolved. }\end{array}$ & & \\
\hline $\begin{array}{l}\text { XXVII. Recognition: } \\
\text { The hero is } \\
\text { recognized. }\end{array}$ & & $\begin{array}{l}\text { The people of his culture reconcile } \\
\text { him in his new heroic role to his } \\
\text { former "normal" role he had before } \\
\text { his departure. }\end{array}$ \\
\hline $\begin{array}{l}\text { XXVIII. Exposure: } \\
\text { The false hero or } \\
\text { villain is exposed. }\end{array}$ & & \\
\hline
\end{tabular}

However long it takes, a hero eventually finds his way home from the adventure and rejoins his culture as a new champion. Both Propp and Campbell acknowledge that any hero, no matter how great, requires help. This underlying structure of the story asserts itself time and time again in the stages of Campbell and Propp. The hero being rescued from the adventure is another example of the constant help a protagonist receives

${ }^{88}$ Vladimir Propp, Morphology of the Folktale, Trans. Laurence Scott (Austin: University of Texas Press, 2008) 57-62. 
throughout the story. ${ }^{89}$ It is within these stages of Propp and Campbell that the citizens of the hero's culture are also re-introduced to the protagonist in this new form. In a way, the hero is no longer a part of his own culture because he has grown into something more. The hero has conquered the adventure, which is something the rest of his culture would have been unable to accomplish. ${ }^{90}$

\begin{tabular}{|l|l|l|l|}
\hline $\begin{array}{l}\text { Vladamir Propp } \\
\text { Morphology of the } \\
\text { Folktale. }\end{array}$ & $\begin{array}{l}\text { Joseph Campbell Hero } \\
\text { with a Thousand Faces }\end{array}$ & Analysis \\
\hline $\begin{array}{l}\text { XXIX. } \\
\text { Transfiguration: The } \\
\text { hero is given a new } \\
\text { appearance. }\end{array}$ & $\begin{array}{l}14 \text { Master of Two } \\
\text { Worlds }\end{array}$ & $\begin{array}{l}\text { Because the hero has become } \\
\text { something more than a normal } \\
\text { citizen of his culture he is given a } \\
\text { new status among his people. }\end{array}$ \\
\hline
\end{tabular}

Before the protagonist ventured into the adventure story he had already mastered the normal mundane world, a task which many fairytale/heroic journey stories are quick to point out is easy. Now, because he has conquered the adventure he becomes something beyond anyone else in his culture. Propp and Campbell both argue that the

\footnotetext{
${ }^{89}$ This help occurs in several different places in both Propp and Campbell. For example Campbell describes a stage of the heroic journey as "supernatural aid" early in his work. The "rescue from without" is another example of this aid. Vladimir Propp talks about the help a protagonist has throughout this story as well. He states, for example: "He is carried away through the air (sometimes he is saved by lightningfast fleeing). The hero flies away on a horse, on geese..." Vladimir Propp, Morphology of the Folktale, Trans. Laurence Scott (Austin: University of Texas Press, 2008) 57.

${ }^{90}$ Campbell discusses this idea of "rescue from without" in greater detail. He states: "The hero may have to be brought back from his supernatural adventure by assistance from without. That is to say, the world may have to come and get him... Society is jealous of those who remain away from it, and will come knocking at the door." Joseph Campbell, The Hero with a Thousand Faces (Princeton: Princeton University Press, 1973) 207.

${ }^{91}$ Vladimir Propp, Morphology of the Folktale, Trans. Laurence Scott (Austin: University of Texas Press, 2008) 62-63.
} 
heroic figure, once returned home, is no longer an "average Joe" of their society but is instead given a new identity that sets him above the rest of the culture. ${ }^{92}$

\begin{tabular}{|l|l|l|}
\hline $\begin{array}{l}\text { Vladamir Propp } \\
\text { Morphology of the } \\
\text { Folktale. }\end{array}$ & $\begin{array}{l}\text { woseph Campbell Hero } \\
\text { with a Thousand Faces }\end{array}$ & Analysis \\
\hline $\begin{array}{l}\text { XXX. Punishment: } \\
\text { The Villain is } \\
\text { punished. }\end{array}$ & 15. Freedom to Live & $\begin{array}{l}\text { The reward for completing the } \\
\text { adventure is essentially peace of } \\
\text { mind. The Villain is no longer a } \\
\text { threat, and the hero is allowed to live } \\
\text { on in peace without that threat. }\end{array}$ \\
\hline
\end{tabular}

The ultimate goal of many adventure stories is the downfall of the villain. This villain is labeled "evil" because he prevents the culture from living normally. Whether this villain is a dragon that eats the village livestock or a rival country which seeks to conquer, the hero is chosen (either directly by his kinsmen or by fate) to eliminate this threat. At the end of the adventure story, this goal has been met and there is no longer a threat to the culture. Propp and Campbell go on to argue that many heroes are part of multiple adventure stories. The Greek protagonist Odysseus became a hero in the Trojan War chronicled by Homer in the Iliad. Further exploits of Odysseus are told in Homer's Odyssey which is the hero's journey home back to Ithaca. Although a hero is allowed to "settle down" after the removal of villain, he is often re-summoned to the adventure world when a new villain threatens his culture.

\footnotetext{
${ }^{92}$ Both Propp and Campbell discuss this idea in great detail. After all the whole point of the quest story is to transform the protagonist from something ordinary into something extraordinary. Propp states: "the hero builds a marvelous palace. He resides in the palace himself as the prince. A maiden suddenly awakens during the night in a marvelous palace. Although the hero is not always transformed in these instances, he nevertheless does undergo a change in personal appearance." The hero will be something different and apart from the rest of society, and that distinction is clearly defined within these mythological stories. Vladimir Propp, Morphology of the Folktale, Trans. Laurence Scott (Austin: University of Texas Press, 2008) 63.

${ }^{93}$ Vladimir Propp, Morphology of the Folktale, Trans. Laurence Scott (Austin: University of Texas Press, 2008) 63.
} 


\begin{tabular}{|l|l|l|l|}
\hline $\begin{array}{l}\text { Vladamir Propp } \\
\text { Morphology of the } \\
\text { Folktale. }\end{array}$ & $\begin{array}{l}\text { woseph Campbell hero } \\
\text { with a Thousand Faces }\end{array}$ & Analysis \\
\hline $\begin{array}{l}\text { XXXI. Wedding: The } \\
\text { hero is married and } \\
\text { ascends the throne. }\end{array}$ & $\begin{array}{l}\text { Ge Meeting of the } \\
\text { Goddes }\end{array}$ & $\begin{array}{l}\text { Propp and Campbell both agree that } \\
\text { while most adventure stories center } \\
\text { on a male protagonist there is always } \\
\text { a female influence, both positive and } \\
\text { negative, on the story. }\end{array}$ \\
\hline
\end{tabular}

Most heroes within any culture are male; however, that fact does not bar female influence from adventure stories. Adventure stories will often end with the marriage of the hero to a woman, who is typically depicted as spectacular in some way. This stage of the adventure story is usually seen in two ways. One is that the hero has fully exited the world of adventure and is now partaking in more "normal world" activities. Also, the spectacular bride of the hero is often a princess or some other woman high on the social hierarchy and so through this union the status of the hero is again raised. Secondly the culture of this hero would see a union between two extraordinary people as natural and fitting. The hero, in a sense, is receiving his just desserts because of his accomplishments. Also, this union is likely to produce extraordinary children. Because children, in the ancient world, often followed the career paths of their parents the offspring of a hero and a spectacular woman would help ensure a new generation of heroic figures. ${ }^{95}$

\footnotetext{
${ }^{94}$ Vladimir Propp, Morphology of the Folktale, Trans. Laurence Scott (Austin: University of Texas Press, 2008) 63-65.

${ }^{95}$ Both Propp and Campbell discuss women in myth stories in multiple ways. Campbell, describes women as both goddess figures who aid the hero, but also as temptresses who deter the hero away from the quest. However, both Propp and Campbell agree that ultimately the hero will unite with a queen, or goddess, or some other extraordinary woman, because an ordinary woman would be unworthy of a hero's love. Campbell writes: "The ultimate adventure, when all the barriers and ogres have been overcome, is commonly represented as a mystical marriage of the triumphant hero-soul with the Queen Goddess of the World. This is the crisis at the nadir, the zenith, or at the uttermost edge of the earth, at the central point of the cosmos, in the tabernacle of the temple, or within the darkness of the deepest chamber of the heart." Joseph Campbell, The Hero with a Thousand Faces (Princeton: Princeton University Press, 1973) 109.
} 
However both Propp and Campbell note a negative female presence in many adventure stories. Propp often wrote about witches that accosted the protagonist of many fairytales. Campbell likewise discussed a woman temptress who distracts the hero away from the heroic journey for a period of time. Either way, Propp and Campbell argue that a female can often divert a hero away from the adventure and so a female in this connotation is another obstacle which the protagonist must overcome to continue the story.

Although the writings of Joseph Campbell do not completely match Vladimir Propp's, it is clear the work of Campbell and Propp are closely related. Both men argued that the main character of adventures, fairytale or heroic quest, went through many different stages that progressed throughout the story. They both argued that an adventure story was almost formulaic in that its progression could be mapped out and charted. Vladimir Propp first published his book Morphology of the Folktale in the late 1920s, decades before Joseph Campbell published Hero with a Thousand Faces. Geroge Lucas read the writings of Campbell and based his story of Star Wars on what he read. Campbell likewise would have almost surely have been at least somewhat familiar with the work of Vladimir Propp. Propp's work can likewise be seen in the Star Wars movies. Propp's work influenced many scholars whose main focus of study was human culture. Media expert Karina Wilson stated in her analysis of the impact Propp's work had on the study of culture that Morphology of the Folktale was a seminal study of cultural relationships. Wilson wrote: 
Propp's work was translated into English in the 1950s, by which time it had become core to the ideas of theorists such as Claude Lévi-Strauss and Roland Barthes, and was used in literary studies, anthropology and semiology. Other narrative analysts extended Propp's thinking on patterns in myth, most notably Joseph Campbell, whose The Hero With A Thousand. Faces has become a blueprint for Hollywood film-makers when it comes to constructing a narrative. ${ }^{96}$

${ }^{96}$ Karina Wilson, "Propp's Analysis of Folktale." (Web. Mediaknowall.com. 2011). 


\section{PROPPS' STRUCTURE AND PLOT IN STAR WARS}

As noted earlier, the Star Wars saga can be divided in two between the story of Luke and the story of Anakin Skywalker. While the story of Luke, comprising of Episodes IV, V, and VI, more accurately illustrate Joseph Campbell's heroic journey, the story of Anakin, comprising of Episodes I, II, and III, more accurately resemble Vladimir Propp's structure of the folk tale. This eclectic development of Star Wars is understandable since different literary traditions went into the making of the film. As was demonstrated earlier, the work of Joseph Campbell can be viewed as a more distilled version of the writings of Propp and can be labeled as a smaller variation of the heroic journey.

In literature, the first sphere of Propp's structure would be labeled exposition, what Propp labeled the "initial situation."97 During this section of the narrative, the writer is telling the audience information needed to fully comprehend the story. In Star Wars, much of the exposition occurs with the "rolling scroll" which imparts through text information needed by the viewing audience. The opening words of every Star Wars movie are "A long time ago in a galaxy far, far away..." Before any other image appears, the audience is told Star Wars is not a current story or a story of the future but is

\footnotetext{
${ }^{97}$ Vladimir Propp, Morphology of the Folktale, Trans. Ariadna Martin and Richard Martin (Minneapolis: University of Minnesota Press, 1984) 25.

${ }^{98}$ Star Wars, Episode IV: A New Hope, Dir. George Lucas (Fox Searchlight Studios and Lucasfilm Ltd., 1977).
} 
instead a story of the past. Also, this story will be set upon a different backdrop other than the one we are familiar with; i.e. a galaxy far, far away.

Anakin Skywalker is a slave born to a mother Shmi Skywalker, portrayed by Pernilla August, but who has no father. It is revealed in the story that Anakin was conceived without the aid of a male donor and was instead conceived by a virgin female. ${ }^{99}$ Myth is replete with miraculous circumstances surrounding the birth of heroic figures. Merlin of the Arthurian legends and Jesus Christ are just two examples of myth stories that involve a virgin birth. ${ }^{100}$ In the same way, Lucas sets up Anakin as a special figure at an early age because of his birth. Additionally, since Anakin had no father, there is a resounding absence of a male influence in his life.

While it is made clear throughout the Star Wars story that Anakin Skywalker has the potential to become a very powerful and successful Jedi, his hubris worries his instructors and retards his ability to complete a successful heroic journey. Anakin is prideful, arrogant, and impatient during his training to become a Jedi knight. In response to Anakin's attitude his master Obi-wan Kenobi, played by Ewan McGregor, gives an interdiction which Anakin then ignores. The greatest example of Anakin's ignoring of the interdiction occurs in Episode II where he kills the "Sand People" in retaliation for his mother's death. ${ }^{101}$ This act is in direct violation of Jedi Law which states that life may be taken only in an act of defense, never aggression. ${ }^{102}$

\footnotetext{
${ }^{99}$ Star Wars Episode: I, The Phantom Menace, Dir. George Lucas (Fox Searchlight Studios and Lucasfilm Ltd., 1999).

${ }^{100}$ Thomas Malory, Le Mort D'Arthur, King Aruthur and of his Noble Knights of the Round Table (London: Simon \& Brown Publishers, 2011).

${ }^{101}$ Star Wars Episode: II, Attach of the Clones, Dir. George Lucas (Fox Searchlight Studios and Lucasfilm Ltd., 2002).

${ }^{102}$ Star Wars Episode: V, The Empire Strikes Back, Dir. Irvin Kershner (Fox Searchlight Studios and Lucasfilm Ltd., 1980).
} 
As the story of Anakin Skywalker unfolds it is revealed that the villain Emperor wishes to recruit Anakin as his agent. There are many scenes in Episodes II and III which the Emperor engages Anakin in conversation in order to seduce him into eventually becoming his agent. It is revealed, for example in Episode III that Anakin had confided in the Emperor about his killing of the Sand People. ${ }^{103}$ In this way throughout the storyline the Emperor is constantly doing reconnaissance in order to achieve his goals.

In the case of the villain Emperor, the reconnaissance pays off as he learns that Anakin has a profound fear of death. Anakin Skywalker's killing of the Sand People in retaliation for the murder of his mother causes to him to make the pronouncement: "Someday I will be able to stop death itself."104 The Emperor uses this piece of information to his advantage by offering Anakin the power to stop death. Believing he is on the path to save his loved ones, Anakin agrees to become an agent of the Emperor in order to obtain the ability to overcome death. ${ }^{105}$

When relating Vladimir Propp's second sphere of morphology to Star Wars, we seek to identify those elements which the heroic figures find themselves lacking. The story of Anakin is the story of a bright young star and his fall from grace. As a tragic hero, Anakin discovers that his path to knighthood is not as easy and as quick as he would like it to be. It is stated repeatedly throughout the saga that the path to becoming a Jedi knight is difficult and those who seek the quick and easy road to this goal fall victim

\footnotetext{
${ }^{103}$ Star Wars Episode: III, Revenge of the Sith, Dir. George Lucas (Fox Searchlight Studios and Lucasfilm Ltd., 2005).

${ }^{104}$ Star Wars Episode: II, The Clone Wars, Dir. George Lucas (Fox Searchlight Studios and Lucasfilm Ltd., 2002).

${ }^{105}$ Star Wars Episode: III, Revenge of the Sith, Dir. George Lucas (Fox Searchlight Studios and Lucasfilm Ltd., 2005).
} 
to the Dark Side of the Force and become instead an agent of evil. ${ }^{106}$ Anakin Skywalker, on his path to becoming a Jedi, finds himself lacking patience, the ability to put the needs of others ahead of his own, as well as punctuated lack of a mastery of his fears. Anakin believes that becoming a Jedi should purge him of these shortcomings.

The third sphere of Propp's structure has the heroic figure seek to solve some problem. The underlying problem that Anakin Skywalker seeks to solve throughout his story is how to conquer death. Anakin is given two solutions to this problem. The first solution comes from the Jedi master Yoda, played by Frank Oz. Yoda, who acts as a type of oracle within the Star Wars movies, advices Anakin that the only true way to conquer death is to accept it. Accept the fact that nothing in life is fixed, and eventually everyone and everything will die off. However, Yoda points out that this is not a sad transformation from life to death, for it is in dying that we become a part of the Force which is ever-present. So by accepting death people can achieve some measure of immortality by becoming a part of the Force that permeates the galaxy. ${ }^{107}$

The second solution Anakin is given to his problem of conquering death comes from the villain Emperor. The Emperor entices Anakin with a tale of a lost secret which allows the possessor of the secret complete mastery over death. Death can be conquered, according to the Emperor, once the secret is learned and used properly. With this secret Anakin would be able to keep everyone he chose from ever dying. In legend, a heroic

\footnotetext{
${ }^{106}$ Star Wars Episode: IV The Empire Strikes Back, Dir. Irvin Kershner (Fox Searchlight Studios and Lucasfilm Ltd., 1980).

${ }^{107}$ Star Wars Episode II: Attach of the Clones, Dir. George Lucas (Fox Searchlight Studios and Lucasfilm Ltd., 2002).
} 
character would choose Yoda's solution to the problem. As a Tragic hero, however, Anakin chooses to believe the Emperor and his secret method of overcoming death. ${ }^{108}$

The fourth sphere of Vladimir Propp's structural analysis involves the hero reclaiming his identity, which is often a difficult task owing to the fact that many people do not believe him to be the hero. Almost immediately after Anakin Skywalker enters the story of Star Wars in Episode I he is hailed as "the chosen one" who it is prophesized will bring balance to the Force. Instead of heralding that balance, however, Episode III ends with Anakin joining the forces of evil and becoming an agent of the Emperor, as well as donning the new persona of Darth Vader. Anakin it would seem is not the hero the Jedi were hoping he would be. However, if we look at the Star Wars saga as a whole complete story from Episodes I through VI we see that in fact Anakin does fulfill the role of the chosen one by bringing balance to the Force through his eventual killing of the Emperor. Skywalker, after killing the Emperor, sheds his Darth Vader identity and reverts to Anakin. ${ }^{109}$

\footnotetext{
${ }^{108}$ Star Wars Episode III: Revenge of the Sith, Dir. George Lucas (Fox Searchlight Studios and Lucasfilm Ltd., 2005).

${ }^{109}$ Star Wars Episode VI: Return of the Jedi, Dir. Richard Marquand (Fox Searchlight Studios and Lucasfilm Ltd., 1983).
} 


\section{CHAPTER IV}

\section{MYTHICAL STRUCTURES IN STAR WARS}

There are many mythical structures discussed by Campbell in combination with Propp that are used in Star Wars. George Lucas mentioned reading the work of Campbell in many different interviews, and Campbell likewise spoke of Lucas writing to him with questions while writing and filming Star Wars. Lucas never mentioned studying Propp, however by 1977, when Star Wars Episode IV was being filmed Propp's work had been translated into English and had influenced scholars around the world. ${ }^{110}$ The similarities between Propp, Campbell, and Lucas have already been discussed so it is important now to discuss how Lucas used the work of Campbell to make Star Wars. The following chart provides a synopsis of some of the structures and elements that Lucas was influenced by with regards to the work of Joseph Campbell.

\begin{tabular}{|l|l|}
\hline I. Departure & \\
\hline Campbell and hero's journey & Lucas and Star Wars \\
\hline The call to adventure & Princess Leia's message \\
\hline The refuse of the call & Must help with the harvest \\
\hline Supernatural aid & $\begin{array}{l}\text { Obi-wan gives Luke his father's Light } \\
\text { Saber Sword }\end{array}$ \\
\hline Crossing the first threshold & Escaping Tatooine \\
\hline The Belly of the whale & Capture by The Death Star \\
\hline
\end{tabular}

\footnotetext{
${ }^{110}$ The Mythology of 'Star Wars', Produced George Lucas and Bill Moyers (For the Humanities production co.: Public Broadcast Services, 2000).
} 


\begin{tabular}{|l|l|}
\hline II. Initiation & Lucas and Star Wars \\
\hline Campbell and the hero & Luke faces himself in the cave \\
\hline The road of trials & $\begin{array}{l}\text { Princess Leia. She wore white in earlier } \\
\text { episodes. }\end{array}$ \\
\hline The meeting of the goddess & Luke is tempted by the Dark Side \\
\hline Temptation away from the true path & Darth and Luke reconcile \\
\hline Atonement with the father & Luke becomes a Jedi \\
\hline Apotheosis (becoming god-like) &
\end{tabular}

\begin{tabular}{|l|l|}
\hline III. The Return & Lucas and Star Wars \\
\hline Campbell and the hero & Luke wants to stay with his dying father \\
\hline Refusal of the return & Millennium Falcon \\
\hline The magic flight & Ewoks help overthrow the Empire \\
\hline Rescue from without & $\begin{array}{l}\text { Millennium Falcon destroys The Death } \\
\text { Star }\end{array}$ \\
\hline Crossing the return & Luke burns the body of his father \\
\hline Master of the two worlds & Rebellion over the Empire is victorious \\
\hline Freedom to live &
\end{tabular}

\section{Departure}

Joseph Campbell describes the "call to adventure" as:

\{signaling\} that destiny has summoned the hero and transferred his spiritual center of gravity from within the pale of his society to a zone unknown. This fateful region of both treasure and danger may be variously represented: as a distant land, a forest, a kingdom underground, beneath the waves, or above the sky, a secret island, lofty mountaintop, or a profound dream state; but it is always a place of strangely fluid and polymorphous beings, unimaginable torments, superhuman deeds, and impossible delight. ${ }^{111}$

So the call to adventure occurs because the protagonist is being summoned away from what he knew and was familiar with, into the unknown realm of adventure.

In Star Wars, the call to adventure is given to the protagonist Luke Skywalker in the form of a distress call from Princess Leia. Princess Leia, as one of the leaders of the Rebellion against the empire, seeks the aid of Jedi knight Obi-wan-Kenobi who resides

${ }^{111}$ Joseph Campbell, The Hero with a Thousand Faces (Princeton: Princeton University Press, 1973) 58. 
on the desert planet Tatooine. Her mission to secure this aid is thwarted by the empire taking her into custody. Unable to secure the aid of Obi-wan, Leia passes her mission to the droids R2D2 and $\mathrm{C} 3 \mathrm{PO}$ who are charged with delivering the request in her stead. Alone on the planet Tatooine, R2D2 and C3PO are captured and sold to Luke Skywalker and his uncle Owen Lars. While cleaning his newly acquired droids, Luke stumbles upon the message meant for Obi-wan-Kenobi being couriered by R2D2. ${ }^{112}$

For Luke, the call to adventure comes from Princess Leia via a message that was intended for someone else. In The Hero with a Thousand Faces, author Joseph Campbell states that the call to adventure can often begin with a mistake. "A blunder-apparently the merest chance-reveals an unsuspected world, and the individual is drawn into a relationship with forces that are not rightly understood." 113 The call to adventure, while seemingly a mistake, is really fate calling the protagonist to grow out of what they are into the hero they were destined to become. In the case of Luke Skywalker he is called to become, through the heroic journey, a Jedi knight.

When the heroic character is faced with the prospect of the journey, he hesitates because of the unknown. He is being asked to venture beyond the comfortable "known" and enter the "unknown" which will shape him into something other than what he is. In essence, the journey is a break from what/who the hero is and knows and forces him to confront the unknown world of adventure. This prospect is frightening, and so the hero will "refuse the call" to adventure, choosing instead to stay where he is comfortable and

\footnotetext{
${ }^{112}$ Star Wars Episode IV: A New Hope, Dir. George Lucas (Fox Searchlight Studios and Lucasfilm Ltd., 1977).

${ }^{113}$ Joseph Campbell, The Hero with a Thousand Faces (Princeton: Princeton University Press, 1973) 58.
} 
safe. In this stage of the heroic journey, the protagonist is faced with a choice either to stay or go. ${ }^{114}$

In Star Wars, Luke is given the call first by Princess Leia in her message and then again by Obi-wan-Kenobi. The droids achieve their mission by delivering Princess Leia's request for aid to Jedi knight Obi-wan-Kenobi. Obi-wan is depicted as a wise old man who possess supernatural powers and extensive knowledge. Kenobi is the first character to speak about the "Force" in the Star Wars saga. Briefly, Kenobi describes the Force as an energy that gives Jedi knights their powers; it binds the galaxy together and penetrates living beings. Obi-wan offers to train Luke in the ways of the Force, allowing him to become a Jedi knight like his father. Luke refuses both calls stating that he must instead help his uncle with the annual harvest. Luke chooses to stay with the familiar thereby refusing the call to adventure. ${ }^{115}$

Every hero on a quest is incapable of accomplishing his goal without some form of aid. Jason had his Argonauts, Robin Hood had his Merry Men, and Luke Skywalker has a menagerie of helpers. Throughout the entire Star Wars saga from Episode I through VI, only four characters are present in each installment: the Emperor who rules, the mentor Obi-wan-Kenobi (who appears as a ghost in episodes V, and VI), R2D2, and C3PO. Known collectively as "the droids," R2D2, played by Kenny Baker, and C3PO, portrayed by Anthony Daniels, fulfill a vital helping role to both Anakin and Luke Skywalker. In classic Greek tragedy a "chorus" acted as a kind of sounding board to the protagonist of the play. Typically the chorus would posses some knowledge that the

\footnotetext{
${ }^{114}$ Joseph Campbell, The Hero with a Thousand Faces (Princeton: Princeton University Press, 1973) 5968.

${ }^{115}$ Star Wars Episode IV: A New Hope, Dir. George Lucas (Fox Searchlight Studios and Lucasfilm Ltd., 1977).
} 
protagonist did not. For example in The Orestia by Aeschylus, The Chorus warned Agamemnon that his wife Clytemnestra was still holding a grudge over his sacrifice of their daughter Iphigenia and that he should proceed with caution. ${ }^{116}$ In the same way, both R2D2 and C3PO hold secret knowledge that no other character possess. It is R2D2 that first brings the message for help from Princess Leia while C3PO serves as an interpreter throughout the journey for both Anakin and Luke, overcoming the language barrier of the different inhabitants of the galaxy. The droids are present throughout all six movies, serving a vital function as helpers to both protagonists throughout the stories.

Another helper character who aids Luke Skywalker through his quest is Han Solo. Jung would describe Han Solo as the Trickster, or Knave archetype, who would fall under the Persona category of "mask." While not inherently evil, his notions of right and wrong are more fluid than the Self archetype. Solo joins Luke on his journey as a helper not because of some noble reason, but instead joins because he is being paid to serve a function. The quest of Luke Skywalker begins by journeying into the unknown. Serving as a type of Gatekeeper in Joseph Campbell's heroic journey, Han Solo can provide passage into the unknown for a fee. Mythology is replete with examples of gatekeeper characters' need for payment before passing; such as the boatman Charon who ferries the dead to the underworld only for those who can pay. But as the Persona archetype Solo has a "mask" which hides his true nature, a nature which reveals itself fully as the story progresses. Because George Lucas based so much of Star Wars on the work of Joseph Campbell, Han Solo is a prime example of Jungian influence in Star Wars. Jungian

\footnotetext{
${ }^{116}$ Aeschylus, Oresteia Trans. Peter Meineck (Indianapolis: Hackett Publishing Company Inc., 1998).
} 
archetypes became a part of Star Wars because Lucas used the work of Campbell who in turn had based much of his theories on the work of Carl Jung.

Jung described the persona as a constant series of interactions between the individual consciousness and society. There is a constant tug-of-war going on in an individual between the person society wants him to be and the person he is when alone. As a result an individual creates a kind of mask, often referred to as the Persona, which is simultaneously designed to make an impression on others while consistently concealing the true nature of the individual. ${ }^{117}$ In Star Wars, the Persona character is Han Solo.

Solo portrays himself to the other characters as the outsider who lives beyond the laws of society. When audiences are first introduced to Han Solo in Episode IV he is depicted as a character who will take no action unless it benefits him in some way. He will not ferry Luke Skywalker and company off Tatooine unless he is paid. He will not help Luke rescue Princess Leia from the Death Star until he is promised a reward. His very name even suggests the Persona he is trying to convey to others: the word solo means alone. However as the embodiment of the Persona this "character" that Han Solo conveys is merely a mask which does give off an aura of strength, but it also conceals something deeper about the personality.

Han Solo is a smuggler by trade. His job is to hide things that he does not wish found so when Solo begins to break away from his selfish lone character and becomes a character that is out for something other than reward and payment marks a change in his

\footnotetext{
${ }^{117}$ Anthony Stevens defines the Persona as: "the mask used by an actor in classical times to represent his role; used by Jung to designate the characteristic roles we individually adopt in relating to others." The Persona was the mask people put on when interacting with others to hide their true nature. Anthony Stevens, Archetypes, A Natural history of the Self (London: Routledge \& Kegan Publishers Ltd., 1983) 299.
} 
character. When audiences are first introduced to Han Solo in Episode IV he is little more than a hired hand who only grudgingly aids Skywalker because the goals of Skywalker are in the best interest of Solo. Solo at first wants money, and then later escape from the clutches of the Empire both of which are obtainable goals if he aids Skywalker. By the end of Episode VI, however, Solo has risen in the ranks of the Rebellion and has achieved the position of general. It is also worth noting that throughout the Star Wars movies, Solo always outranks Luke in the Rebellion army. In Episode V Luke is a Commander, and Han is a Captain. In Episode VI Han is a General and Luke a Captain which serves as a small reminder to audiences just how important this Persona character is to the Star Wars story. Solo goes from a selfish character who is only interested in those things which help him out, to a character who leads others and plays a key role in the final toppling of the Empire. ${ }^{118}$

Han Solo's persona is designed to create an aura of mystery about the character which introduces an unknown variable into the story of Star Wars. What exactly is Han Solo going to do? When it comes right down to it will he fight for his friends, or will he choose instead to fight for his own best interests? But despite all the misgivings that Solo may give to his fellow characters, he is a constant source of help to the heroic protagonist Luke Skywalker. Han Solo represents a form of support which is vital to the successful completion of Skywalker's heroic journey. Solo provides a type of "mundane" aid to Skywalker such as shuttling the characters from place to place. This type of aid is important to Skywalker because Solo fills a necessary logistical function. But in terms of the heroic journey, "mundane" aid is not enough help.

\footnotetext{
118 The key role Han Solo plays in the final battle with the Empire can be seen in Star Wars Episode VI: Return of the Jedi, Dir. Richard Marquand (Fox Searchlight Studios and Lucasfilm Ltd., 1983).
} 
In heroic journeys the protagonist is helped with his adventure through supernatural aid. Symbolically, this supernatural aid is a blessing from the gods, who approve of the heroic journey. In myth, the Greek hero Perseus was given a helmet of invisibility and a magical shield from the god Zeus to aid him in his journey to kill Medusa. By giving Perseus these magical items, Zeus helped Perseus achieve the goal of his heroic journey. ${ }^{119}$

In Star Wars, the Jedi knights embody a supernatural presence in the galaxy. Possessed with magical powers, the Jedi knights have the power of mind control, the power of telekinesis, and even the ability to manifest and channel lightning through their hands. To have a Jedi knight fighting for you is to have supernatural aid. And the most recognizable weapon of the Jedi knights is the light saber, a contained and deadly beam of light.

As Obi-wan-Kenobi explains the mysteries of the Force, and attempts to secure Luke Skywalker's accompaniment to the Rebellion, he also reveals that he was once a close friend to Luke's father Anakin Skywalker. Obi-wan states that Luke's father was once a Jedi knight, which is a revelation to Luke, and that he bequeathed his light saber to his son. Obi-wan fulfills the wishes of Anakin and passes the light saber to Luke. ${ }^{120}$ By obtaining the light saber sword, Luke obtains the supernatural aid of the Jedi knights.

In myth, the unknown world of adventure is often demarcated by a guardian obstacle. In order to enter and commit fully to the adventure quest, the hero must overcome this first of many obstacles. "Crossing the First Threshold" symbolically is a statement by the hero that he is fully committing himself to the journey. It is a first

\footnotetext{
${ }^{119}$ Edith Hamilton, Mythology (New York: Little, Brown and Company Publishers, 1998) 197-208.

${ }^{120}$ Star Wars Episode IV: A New Hope, Dir. George Lucas (Fox Searchlight Studios and Lucasfilm Ltd., 1977).
} 
breaking away from his previous "known" world as well as his first steps into the "unknown" world of adventure. Joseph Campbell states that the heroic character sets himself apart from the rest of his society because of his willingness to step into the adventure. "The usual person is more than content, he is even proud, to remain within the indicated bounds, and popular belief gives him every reason to fear so much as the first step into the unexplored." ${ }^{\prime 21}$ The audiences of myth therefore see the heroic character as something different from the rest of his society because of his willingness to cross that first threshold.

For Luke Skywalker, the first threshold is easily defined as escaping from his planet Tatooine. On Tatooine, the Empire is searching for the droids which contain information about a way to destroy the Empire's ultimate weapon the Death Star. Going so far as to kill Luke's aunt and uncle, the Empire will go to any lengths to retrieve the information about the weakness of the Death Star. Obi-wan-Kenobi, Luke Skywalker, C3PO, and R2D2 must escape from Tatooine before being discovered by the Empire. ${ }^{122}$

In The Hero with a Thousand Faces Campbell illustrates how a hero must overcome some obstacle before he is allowed to cross the first threshold and enter into the unknown world of the quest. This obstacle usually takes the form of a troll living under a bridge leading out of the village, or a water demon that lives in a river which must be crossed. This obstacle represents the boundary between the "known" world of the protagonist (i.e. the village) and the unknown realm of the quest. In psychological

${ }^{121}$ Joseph Campbell, The Hero with a Thousand Faces (Princeton: Princeton University Press, 1973) 78.

${ }^{122}$ Star Wars Episode IV: A New Hope, Dir. George Lucas (Fox Searchlight Studios and Lucasfilm Ltd., 1977). 
terms, the village equals order/safety and the quest chaos/peril. ${ }^{123}$ In Star Wars, the obstacle that Luke Skywalker must overcome before he enters into his quest is passage off the planet Tatooine. Just as other heroes must first cross the bridge leading out of the village, so too must Skywalker leave his home planet.

Han Solo then would be the equivalent counterpart of the troll living under the bridge which blocks Skywalker's route. Han Solo is a smuggler who is paid to take cargo from one destination to another undetected by the Empire. Jedi master Obi-Wan Kenobi and Luke Skywalker wish to be taken from Tatooine to the Rebellion on the planet Alderaan. As a hired smuggler, Han Solo expects payment for his services, payment which Kenobi and Skywalker cannot afford because Han Solo demands upfront payment in full. This situation is the obstacle which Skywalker must overcome if he is to begin his heroic quest. Han Solo is therefore a type of gatekeeper who guards Skywalker's first threshold demanding payment for passage. In Greek mythology, the underworld was bordered by the river Styx which the dead must cross in order to enter the afterlife. The souls of the dead would be ferried across the river by the boatman Charon. Charon did not perform this task for free, however, and the departed were expected to pay the boatman with a coin. Those who could not pay were denied passage. ${ }^{124}$ Han Solo is the Charon counterpart because of his demand of payment for his serves of ferrying Skywalker and party across the first threshold. In myth heroes such as

\footnotetext{
${ }^{123}$ Joseph Campbell describes many different scenarios in which the protagonist must transgress some type of line of demarcation in order to set forth on his journey. Campbell states: "With the personifications of his destiny to guide and aid him, the hero goes forward in his adventure until he comes to the 'threshold guardian' at the entrance of the zone of magnified power. Such custodians bound the world in the four directions... standing for the limits of the hero's present spehere, or life horizon. Beyond them is darkness, the unkonw, and danger; just as beyond the parental watch is danger to the infant and beyond the protection of his society danger to the member of the tribe..." Joseph Campbell, The Hero with a Thousand Faces (Princeton: Princeton University Press, 1973).

${ }^{124}$ Edith Hamilton, Mythology (New York: Little, Brown and Company Publishers, 1998) 330-333.
} 
Jason would enlist the aid of a ship, the Argos, to carry them on their heroic journey. ${ }^{125}$ In Star Wars, the ship is the Millennium Falcon piloted by Han Solo and Chewbacca. Solo agrees to ferry Luke and his friends away from Tatooine for a price. Once in outer space, a brief skirmish ensues resulting in the eventual escape of the Millennium Falcon and her complement of passengers away from the planet Tatooine. With the crossing of the first threshold, Luke fully commits himself to the heroic journey and breaks away from his life as a farmer. ${ }^{126}$

The heroic journey is full of obstacles and tests that the protagonist must overcome in order not only to continue on his quest, but also continue his transformation into the heroic character this journey is shaping him in to. One of the trials and tribulations that many heroic characters must overcome is known in myth as "The Belly of the Whale." Taken literally from the biblical story of "Jonah and the whale," this transformative stage is for the protagonist. In the biblical story Jonah is swallowed by a large fish, often depicted as a whale in popular myth, because he refused to perform the task God had set him. The three days Jonah spent inside the fish were designed to change Jonah's mind. ${ }^{127}$ Likewise this stage of the heroic journey is designed to start the transformation of the protagonist because something will be different about the character once he emerges from the belly of the whale.

The short-term goal of the Luke Skywalker and his menagerie, in Episode IV, is to deliver the droids to the Rebellion on Princess Leia's home planet Alderaan. This goal is altered, however, when the Millennium Falcon reaches the coordinates of the planet

\footnotetext{
${ }^{125}$ Edith Hamilton, Mythology (New York: Little Brown and Company Publishers, 1998) 163-175.

${ }^{126}$ Star Wars Episode IV: A New Hope, Dir. George Lucas (Fox Searchlight Studios and Lucasfilm Ltd., 1977).

${ }^{127}$ Michael Coogan, The New Oxford Annotated Bible (New York: Oxford University Press, 2001).
} 
only to discover it has been destroyed by the Death Star which then proceeds to capture the ship. Once inside the massive Death Star, the short-term goals therefore become freeing imprisoned Leia and escaping. The Death Star is the mythological counterpart of the whale which will be a transformative experience for Luke. This transformation occurs when the villain Darth Vader slays Luke's mentor Obi-wan-Kenobi. In effect, the belly of the whale broke much of Luke's naiveté by forcing him to face the loss of his teacher and surrogate father.

Luke is raised by his uncle Owen Lars, the step-brother of Anakin Skywalker, and his wife Beru Lars. It is revealed early in Episode IV that Luke has been told that his father died during a time referred to as the "Clone Wars." Luke does not refer to Owen as "father" nor Beru as "mother" and so Luke is depicted as a character who is noticeably lacking in parental figures. Notice as well that Luke has a different last name than does Owen and Beru which serves to underscore his lack of parentage. And while the mantle of "mother" is never filled, the "father" figure is taken up by the various mentors Luke encounters throughout his journey because the role of the father was never taken up by Owen and is unable to be filled by the biological father Anakin Skywalker now known as Darth Vader.

The word mentor comes from the Greek myth of Odysseus. Before he set sail to join the Trojan War, Odysseus places his son Telemachus in the care of an elderly wise man named Mentor. ${ }^{128}$ So the role of the mentor is to serve as a segregate father figure who watches over, protects, and teaches a young man.

In Star Wars the role of the mentor to Luke Skywalker is filled by Obi-wan Kenobi and Yoda. The goal of both mentors is to teach Luke about the ways of the Force

${ }^{128}$ Edith Hamilton, Mythology (New York: Little, Brown and Company Publishers, 1998) 296-297. 
which will not only allow him to complete his personal ultimate goal of becoming a Jedi, but which will also give him the skills necessary to reach the end of the heroic journey. In essence, the mentors of Star Wars are teaching/training Luke to be a hero. In that regard they are like Chiron, the mythological teacher of the Greek hero Achilles. ${ }^{129}$ The purpose of the mentor figure is to give the hero the knowledge and skills which are needed to complete the heroic quest.

The training that a young hero must endure is arduous because he must not only break away from what he was (normal) but he must also allow himself to be reformed into something else (hero). This difficult training understandably becomes a bonding experience between mentor and protégé as camaraderie is built. As mentor and protégé become closer, the mentor fills the role of the absent father. In his book Archetypes, $a$ Natural History of the Self, Anthony Stevens says this about the Jungian archetype of the father:

In myth, legend and dreams, the father archetype personifies as the Elder, the King, the Father in Heaven. As Lawgiver he speaks with the voice of collective authority and is the living embodiment of the Logos principle: his word is law. As Defender of the Faith and of the Realm he is the guardian of the status quo and bastion against all enemies... His symbols are heaven and the sun, lightening and wind, the phallus and the weapon... ${ }^{130}$

If we were simply to look at the mentor Yoda we can see how as a Jedi Master he fulfills the Jungian criteria of the father archetype. He is the elder, head of and last Jedi left in the galaxy. As the Lawgiver, he speaks with the voice of collective authority the teachings of the Jedi. The teachings he bestows upon Luke are the absolute indisputable

\footnotetext{
${ }^{129}$ In Greek mythology, Chiron was described as a teacher of many great heroes including Achilles, Jason, Peleus, Actaeon, Aristaeus, and Medus. Edith Hamilton, Mythology (New York: Little, Brown and Company Publishers, 1998) 48, 414, 430, 92.

${ }^{130}$ Anthony Stevens, Archetypes: A Natural History of the Self (London: Routledge \& Kegan Publishers Ltd., 1983) 105.
} 
law of the Jedi which is depicted in a few different scenes in Episode V. The symbol of Yoda, which is the symbol of the Jedi themselves, is the light saber which can be viewed as a weaponized bolt of lightning. Luke's mentors all bestow upon him the information and skills he needs in order to become the hero, to in effect achieve his fullest potential. Therefore the mentors become the father figures of Luke Skywalker.

\section{Initiation}

Once the protagonist has fully committed himself to the heroic journey, he begins to experience a series of trials which will ultimately shape him into the heroic figure. Each trial is also a test which the hero must pass in order to continue on his journey. In myth the most obvious example of these trials is the Greek hero Odysseus who spent ten years of trials after the Trojan War making his way home to Ithaca. The Cyclops, the Sirens, the witch Calypso... were all trials which tested Odysseus. Only by overcoming these trails was Odysseus was able to continue on his journey. ${ }^{131}$

Campbell labels this ongoing series of tests: "The Road of Trials." This stage of the heroic journey is significant because it is a series of events designed to shape and teach the heroic character what he needs to know in order to evolve and ultimately accomplish his goals. In essence, the road of trials is designed so the protagonist can find the heroic figure within. ${ }^{132}$ The Hero with a Thousand Faces says this about the road of trials:

\footnotetext{
${ }^{131}$ Homer, The Odyssey, Trans. W.H.D. Rouse (New York: Penguin Books Group, 1937).

132 Campbell described the "Road of Trails" as a continuation of the obsticals the protagonist first encountered in the "Crossing the First Threshold" stage of the quest. Campbell states: "The original departure into the land of trials represented only the beginning of the long and really perilous path of initiatory conquests and moments of illumination. Dragons have now to be slain and surprising barriers passed again, again, and again." Joseph Campbell, The Hero with a Thousand Faces (Princeton: Princeton University Press, 1973) 97-109.
} 
The hero, whether god or goddess, man or woman, the figure in a myth or the dreamer of a dream, discovers and assimilates his opposite (his own unsuspected self) either by swallowing it or by being swallowed. One by one the resistances are broken. He must put aside his pride, his virtue, beauty, and life, and bow or submit to the absolutely intolerable. Then he finds that he and his opposite are not of differing species, but one flesh. ${ }^{133}$

Often unwillingly, the protagonist of a heroic quest story is thrust onto the path of the journey which will make him into the heroic figure. At this stage of development, the protagonist is a dichotomy of who he was, and who is becoming. He is a mixture of what he was and what he will be. The road of trials forces the protagonist to face and become the heroic figure.

Star Wars Episode I reveals that in order to become a Jedi knight, the Paduwan (or student) must undergo a series of trials before initiation into the order. One of these trials forces the Paduwan to come face to face with his inner self and understand what is at his core. In Episode V Luke Skywalker seeks the training of Jedi master Yoda, voiced by Frank Oz. Through his tutelage, Luke grows in his Jedi abilities. One of the trials that Luke must endure at the direction of Yoda is to enter a cave where he suddenly is forced to duel his enemy Darth Vader. In the cave Luke defeats Vader through decapitation. Once the helmet of the decapitated Vader is removed, Luke sees his own face behind the mask. This revelation is one of the trials which Luke must overcome if he is to continue on his journey to becoming a Jedi knight. As a symbol of evil Luke is forced, during this trial, to acknowledge his own internal evil. ${ }^{134}$

Although the majority of heroic journeys involve male protagonists there is still a female presence in male heroic journeys which typically takes the form of a goddess.

\footnotetext{
${ }^{133}$ Joseph Campbell, The Hero with a Thousand Faces (Princeton: Princeton University Press, 1973) 108.

${ }^{134}$ Star Wars Episode V: The Empire Strikes Back, Dir. Irvin Kershner (Fox Searchlight Studios and Lucasfilm Ltd., 1980).
} 
Again taking the example of Homer's Odyssey, the hero Odysseus is aided by the goddess Athena on his heroic journey home. ${ }^{135}$ In the heroic journey this stage is known as "The Meeting with the Goddess" and involves the hero obtaining the aid of the feminine. It is vital that the hero gain this aid for only through the help of the goddess can the hero achieve the goal of his quest.

Typically in myth the goddess represents some knowledge that the hero is lacking. In Egyptian myth, for example, the goddess Isis obtained the secret of resurrection in order to bring her husband Osiris back from the dead. ${ }^{136}$ The goddess of myth represents a new perspective, a new way of looking at things that the hero does not possess. And it is only by obtaining this perspective from the goddess that the hero can see the larger picture and therefore achieve the goal of his quest.

In Star Wars, the goddess is represented by Princess Leia. In Episode IV when Luke Skywalker first sets out to rescue the Princess from The Death Star what he is in fact doing is securing the goddess perspective which will be vital to the achievement of his quest. Princess Leia is not, however, the typically damsel in distress but is instead one of leaders of the Rebellion. In the early episodes of the Star Wars saga Leia is dressed in stark white clothing denoting her mythical significance. White is often the symbol of purity and virginity and many goddess figures are dressed in white clothing. Conversely the Empire has no female character present within their ranks and as such never secured the aid of the feminine.

As noble and as worthy as any heroic journey may be, it is difficult because of the trials and tribulations which test the protagonist at every turn. It is therefore unsurprising

\footnotetext{
${ }^{135}$ Homer, The Odyssey Trans. W.H.D. Rouse (New York: Penguin Books Group, 1937).

${ }_{136}$ Arthur Contterell and Rachel Storm, The ultimate Encyclopedia of Mythology (New York: Anness Publishing Limited, 2003) 290.
} 
that one of the tests a heroic character must endure is a "temptation away from the true path." This stage of the journey is where the heroic character is offered a much easier and simpler path than the one he is currently enduring. Often taking the form of a female temptress, the protagonist is faced with a choice to either continue on knowing that more trials and tests await, or turn to a much easier and seemingly rewarding path. Joseph Campbell termed this stage of the heroic journey as "Woman as Temptress."137 The Greek hero Odysseus, for example, spends a year with the witch Circe (with whom he fathers children) before he re-commits himself to his journey home. The time Odysseus spends with Circe is a deterrent away from his ultimate goal, i.e. his return to his homeland Ithaca. ${ }^{138}$ During this stage of the heroic journey, the protagonist must recommit himself to the goal of the quest.

In Star Wars this temptation away from the true path occurs when a Jedi knight is tempted by the dark side of the Force. Yoda describes the dark side as "the quick and easy path" which is powerful and by far the more seductive than the good side of the Force. $^{139}$ In Episode V, after training with Yoda in the ways of the Force, Luke Skywalker learns that his friends are being held to lure him away from his training so he can be captured by the Empire. Against the wishes of his master Yoda, Luke journeys to save his friends where he is confronted by Darth Vader. After a battle which leads to the loss of Luke's hand, Vader offers Luke the chance to join forces in order to overthrow the

\footnotetext{
${ }^{137}$ Joseph Campbell describes two different types of women in his heroic journey. The first is the goddess type who aids the hero on his journey, while the other is a temptress who acts as a distraction away from the journey. Often this "temptress" will not be a flesh and blood female, but will instead be some other type of temptation which, if chosen, will steer the hero from the path of the journey. Joseph Campbell, The Hero with a Thousand Faces (Princeton: Princeton University Press, 1973) 120-126.

${ }^{138}$ Depending on which source is used, Odysseus spent only one year, or many more on the island of Aeaea where they parented two or more children. Edith Hamilton, Mythology (New York: Little, Brown and Company Publishers, 1998).

${ }^{139}$ Star Wars Episode V: The Empire Strikes Back, Dir. Irvin Kershner (Fox Searchlight Studios and Lucasfilm Ltd., 1980).
} 
Emperor and rule the galaxy together. The temptation of Luke by the dark side of the Force reveals two important truths to the audience. One is that Darth Vader was once Anakin Skywalker and is therefore Luke's father. And the second is that Vader is not as dedicated to the Emperor as Luke is to his friends. Vader offers to overthrow the Emperor in order to gain power for himself. Luke on the other hand is willing to sacrifice himself for the safety of his friends and allies. ${ }^{140}$ In the end Luke refuses the temptation and continues on his heroic journey.

The actions of the Emperor are the driving force behind the story of Star Wars. Because of his actions everything else happens. Were it not for his desire for power and his oppressive actions towards the citizens of the galaxy then Queen Amidalla would never have been attacked. If she had never been attacked, then she never would have landed on Tatooine and never met Anakin Skywalker which resulted in the births of Luke and Leia Skywalker. ${ }^{141}$ Years later, the actions of the Emperor caused the formation of the Rebellion which threw the galaxy into civil war. The actions of the Emperor are what move the story of Star Wars along. And while the actions of the other characters (e.g. Luke, Leia, Amidalla, Anakin, Solo, Chewbaca) are by no means trivial, the galaxy would still have been thrown into the civil war because of the Emperor. The Emperor is the main plot device George Lucas uses in story of Star Wars. It is because of the actions of the Emperor that the question becomes: "what happens to the galaxy?"

Sigmund Freud speculated that a boy will emulate his father as his model to achieving adulthood. Eventually, however, the boy must break away from his father's

\footnotetext{
${ }^{140}$ Star Wars Episode V: The Empire Strikes Back, Dir. Irvin Kershner (Fox Searchlight Studios and Lucasfilm Ltd., 1980).

${ }^{141}$ Star Wars Episode I: The Phantom Menace, Dir. George Lucas (Fox Searchlight Studios and Lucasfilm Ltd., 1999).
} 
model and grow into adulthood on his own terms. Through this breaking away a boy becomes a man. Freud stated that during this process the boy will have the urge to conquer his father because he sees him as a potential rival, a phase he termed "Oedipus Complex."142

Child-parent relationships such as the ones Freud described can be most clearly seen in hunter/gather cultures. As the son continues to grow and develop psychologically and physically he begins to take on a new role within the community. A boy eventually grows into a man and undertakes the task of feeding/defending the society. During this time, there is an overlap where both father and son are filling the same roles within the community. The father, while not yet retired, continues to hunt and defend the society. His son, once he reaches manhood, joins his father in hunting and defending the society. At this point both father and son are forced to become allies in these dangerous activities of hunting and defense. Once this alliance is forged, the son no longer sees his father as a rival, and the father no longer sees his son as a boy. All boys regardless of cultural specifics undergo some form of this stage of development where their relationship with the father becomes something other than what it was during childhood. It is through this stage of development that boys grow into men.

In myth, this stage is known as "Atonement with the Father" and is significant because it is a breaking away from the previous model of the father and allows the son to create his own persona. In this stage of the myth, the hero continues on his path to achievement of his goal not because it is what his father (or his society) expects of him

${ }^{142}$ Anthony Stevens, Archetypes: A Natural History of the Self (London: Routledge \& Kegan Publishers Ltd., 1983) 127-130. 
but because he chooses to continue on his own terms. ${ }^{143}$ In Greek myth the hero Hercules struggled with his dual identity of being half god, as the son of Zeus, and half mortal, as the son of Alcemene. ${ }^{144}$ It was only through his confrontation of his dual nature that he was finally able to become a truly heroic figure.

Luke Skywalker starts his heroic quest by wishing to emulate his father and achieve the rank of Jedi knight. This emulation of his father becomes problematic when he learns in Episode V that his father is the evil Darth Vader. Luke's goal of becoming a Jedi does not change with this revelation and he continues on his path to Jedi knighthood. Episode VI finds Luke asking his dying master Yoda what task remains to his achievement of becoming a Jedi. Yoda states that the only trail that remains for Luke is to face Darth Vader once again. Symbolically, Yoda is forcing Luke into a situation where he will either achieve atonement with his father, or else fall to the dark side of the Force. Those are the only two choices that Luke is given, either to face Vader and achieve some type of closure or else allow the Empire to win the War of the Galaxy. In essence the choice Luke faces is either to become a copy of his father, or else to grow beyond his father into his own person. ${ }^{145}$

Luke chooses to face Vader once again and he proceeds to turn himself over to the Empire. The goal of Luke is not to kill his father, however, but to turn Vader from the dark side of the Force back to the good. Although resistant at first, Vader eventually

${ }^{143}$ Joseph Campbell, The Hero with a Thousand Faces (Princeton: Princeton University Press, 1977) 126149.

${ }^{144}$ Edith Hamilton, Mythology (New York: Little, Brown and Company Publisher, 1998) 224-243.

${ }^{145}$ A large portion of Episode VI is dedicated to Luke Skywalker struggling with the true identity of his father. As an officer of the Rebellion, it is his duty to stop Darth Vader and the Empire. Additionally if he wants to become a Jedi knight in full, he must again confront Darth Vader. But as a son, he struggles and hesitates because he has no wish as a son to destroy his father. That is the conundrum of Episode VI. Star Wars Episode VI: Return of the Jedi, Dir. Richard Marquand (Fox Searchlight Studios and Lucasfilm Ltd., 1983). 
gives in to Luke and turns from evil in order to save his son's life and kill the Emperor. Luke is thereby able to achieve a sense of wholeness as he harmonizes the dual nature of his self.

As was stated earlier, Anakin Skywalker is set up as an anomaly within the Force because of his virgin birth. Jedi Qui-gon Jinn believes that this miraculous birth is an indication that Anakin Skywalker is a prophesized hero known as "The Chosen One" who, it is said, will bring balance to the Force. To become a Jedi knight at all is to be considered rare, but to be a prophesized hero in addition means that Anakin was unique and special. As both unique and special the Jedi knights expected Anakin to grow into a truly exceptional warrior who would somehow find a way to vanquish the enemies (i.e. the sith) of the Jedi. The expectations of the Jedi go unfilled as Anakin turns from the teachings of the Jedi and falls to the dark side of the Force. ${ }^{146}$

Anakin Skywalker first turned to the dark side of the Force in a misguided attempt to save his wife Padme from dying. He believed that the Emperor held the secrets needed and so he made a Faustian deal of servitude in return for the Emperor's aid. Anakin then proceeds to help the Emperor destroy and kill all Jedi knights and in doing so ceases to be Anakin and becomes Darth Vader. ${ }^{147}$ Filmmaker George Lucas compares Anakin's decent into darkness as being akin to Lucifer's own fall from grace. ${ }^{148}$ As the villain Darth Vader, Anakin becomes the epitome of "the bad guy" because of his killing of children, and torture of other characters. ${ }^{149}$ It is therefore

\footnotetext{
${ }^{146}$ Star Wars Episode I: The Phantom Menace, Dir. George Lucas (Fox Searchlight Studios and Lucasfilm Ltd., 1999).

${ }^{147}$ Star Wars Episode III: Revenge of the Sith, Dir. George Lucas (Fox Searchlight Studios and Lucasfilm Ltd., 2005).

${ }^{148}$ Star Wars: Trilogy, Produced George Lucas (Fox Searchlight Studios and Lucasfilm Ltd., 1995).

${ }^{149}$ Star Wars Episode III: Revenge of the Sith, Dir. George Lucas (Fox Searchlight Studios and Lucasfilm Ltd., 2005).
} 
understandable that few people see any redemption for "The Chosen One" because of the acts of these acts of cruelty and villainy. However Anakin's son Luke wishes to try.

Episode VI is the denouement, the third and final act, all loose ends are tied up and the audience is given a sense of closure. The Jedi knights believed that Anakin Skywalker was destined to bring balance to the Force. It was assumed that he would accomplish this goal by fighting as a powerful Jedi knight on the light side of the Force. After his decent into darkness in Episode III, many people would assume that the Jedi knights were wrong and that Anakin was not in fact the prophesized "Chosen One." However, when the entire Star Wars saga is looked at as a whole complete story it begins to become clear that Anakin did fulfill the prophecy.

By the time period of Episode VI, the Emperor assumes that Darth Vader is squarely and securely his obedient servant. As his obedient servant, the Emperor orders Vader to fight his own son Luke Skywalker. As Luke Skywalker confronts Darth Vader, he overcomes the final obstacle to knighthood and becomes a full Jedi, thereby becoming god-like and achieving Apotheosis. Luke wins the fight against Vader and is ordered by the Emperor to kill his father and take his place as his obedient servant. Luke then refuses the orders of the Emperor. The Emperor, still wishing to wipe out the entire Jedi knighthood, proceeds to kill Luke Skywalker slowly in front of Darth Vader. It does not even occur to him that Darth Vader would turn against him and choose to save the life of his son. ${ }^{150}$

As the Emperor tortures Luke, Darth Vader is faced with a choice between the Emperor of his making, or his only son. In a very Christian act of sacrifice, Vader

\footnotetext{
${ }^{150}$ Star Wars Episode VI: Return of the Jedi, Dir. Richard Marquand (Fox Searchlight Studios and
} Lucasfilm Ltd., 1983). 
chooses to save his son by killing the Emperor which in turn leads to his own death shortly after. ${ }^{151}$ Christianity often speaks of a person's need to sacrifice in order to grow stronger in the faith and become closer to God. Catholicism particularly has many saints who have martyred themselves for their faiths. The legend of St. Lawrence, for example, tells how the Roman Deacon was slowly roasted alive on an iron grill because of Christian faith. It is through this similarly Christian act of sacrifice that Vader is granted redemption and fulfills the prophecy. Killing the Emperor is the act which brings the balance back to the Force. The embodiment of dark side (the Emperor) is destroyed by the "Chosen One" (Anakin Darth Vader Skywalker).

Audiences are given a sense of closure to the dual nature of the Anakin/Vader character in the closing scene of Episode VI. In this scene, the ghosts of now dead Jedi Obi-wan and Yoda appear to Luke in a congratulatory proud moment. The ghost of Anakin Skywalker, now stripped of his Darth Vader mask, joins the duo and smiles. ${ }^{152}$ This scene is very important mythologicaly because it shows the redemption of Anakin, and the atonement of Luke with all his father figures.

\section{The Return}

Once the ultimate goal has been reached, the hero experiences a moment of disillusionment when he realizes his quest has come to an end. The quest has shaped,

\footnotetext{
151 The Christian Bible speaks often of sacrifice. The books of Leviticus and Mark, for example, specifically talk about sacrifice. Jesus Christ himself sacrifices himself in order to forgive the sins of all mankind. One of the most popular of all bible passages, however, is John 3:16 (a verse that can often been seen on a poster at sporting events). It states: "For God so loved the world that he gave his only Son, so that everyone who believes in him may not perish but may have eternal life." This passage demonstrates that, to Christians, God was willing to sacrifice his only Son so that others could be saved. Michael Coogan, The New Oxford Annotated Bible (New York: Oxford University Press, 2001).

${ }^{152}$ Star Wars Episode VI: Return of the Jedi, Dir. Richard Marquand (Fox Searchlight Studios and Lucasfilm Ltd., 1983)
} 
honed, and reformed the protagonist into a character who is no longer the same "common" person he was when he first set out on this journey. The quest has replaced his old life and the journey has become his life. This stage of the heroic journey is similar to the earlier stage in which the protagonist will refuse the call of the adventure. In both cases, the hero is forced to leave behind what he knows, what he has become accustomed to and step into a new role. Joseph Campbell called this stage of the heroic journey the "Refusal of the Return" and it occurs when the quest has ended, but the protagonist clings to it still. ${ }^{153}$

In Star Wars, this stage of the heroic journey comes when Luke Skywalker refuses to leave his dying father in the decaying Death Star. In Episode VI Luke fulfills his quest by becoming a Jedi and Anakin carries out his own destiny as the "Chosen One" by killing the Emperor. Darth Vader, at this point in the story, has been wounded during his duel with Luke and is therefore in a weakened state. The method by which Darth Vader kills the Emperor is by picking him up over his head and throwing the Emperor over the side of a chasm. As the Emperor is hoisted above his head, Darth Vader is hit with a large amount of lightening issuing from the Emperor's hands. This lighting strike, combined with his earlier sustained injuries, causes Vader to begin to die slowly. Luke, whose life has just been saved by his now redeemed father, tries to escape with his father in tow. Outside the Death Star the Rebellion has been mounting a constant attach on the star base in the hopes of destroying it. Luke is now encased in a Death Star which is

${ }^{153}$ Joseph Campbell, The Hero with a Thousand Faces (Princeton: Princeton University Press, 1977) 193196. 
about to explode, and is literally dragging Darth Vader behind him in an attempt to save both himself and his father. ${ }^{154}$

Luke knows that his father is about to die, and he knows too that the Death Star is about to be destroyed, yet he refuses to leave. Luke Skywalker has achieved the goals of the heroic journey by becoming a Jedi knight and ensuring victory for the Rebellion over the Empire. Luke is being called to rejoin society, and the Rebellion, but instead tries to stay within the heroic journey, the Death Star. During the last moments of Episode VI Luke asks the same question many heroes ask at the end of their own journey: "The quest is done and my goals have been met. Now what?"155 The unknown answer to this question is what causes Luke to refuse the call of the return.

Eventually the heroic figure of a quest story will, usually, choose to accept the call of the return and leave the quest and rejoin society. At this point, once the hero has decided to return, a "Magical Flight" occurs which will take the hero back to society. This stage of the heroic journey is a type of announcement to society that a heroic figure has returned. The magical flight is a grand entrance for a character who has themselves become someone grand. The magical flight serves as a form of proof to the people of society that this person has become something special. ${ }^{156}$

${ }^{154}$ Star Wars Episode VI: Return of the Jedi, Dir. Richard Marquand (Fox Searchlight Studios and Lucasfilm Ltd., 1983).

${ }^{155}$ Joseph Campbell discusses in length how the heroic figure will often try and stay with the adventure story and shun a return to the culture he left behind at the start of his story. Often this refusal will be born out of fear, just as it was when the hero first refused to go on the quest story. The hero will fear, for example, that they will no longer fit into the culture they left behind, or that they have changed so much that they will no longer be able to relate to those members of the culture. Joseph Campbell states: "...the responsibility has been frequently refused. Even the Buddha, after his triumph, doubted whether the message of realization could be communicated, and saints are reported to have passed away while in the subernal ecstasy. Numerous indeed are the heroes fabled to have taken up residence forever in the blessed isle of the unaging Goddess of Immortal Being." Joseph Campbell, The Hero with a Thousand Faces (Princeton: Princeton University Press, 1977) 193.

${ }^{156}$ Joseph Campbell, The Hero with a Thousand Faces (Princeton: Princeton University Press, 1977) 196207. 
In Greek mythology, the hero Jason is ferried back to society from his quest to obtain the Golden Fleece by his famed ship the Argo. The Argo is described in myth as a massive ship who the goddess Athena helped design and contained a piece of sacred timber as the bow which would always steer the ship correctly. In myth, then, the Argo was a special and sacred ship. ${ }^{157}$ The Star Wars counterpart of the Argo is the Millennium Falcon.

The Millennium Falcon is the ship which ferries the hero Luke and his menagerie of companions throughout the heroic journey. The Millennium Falcon first took Luke away from his home planet Tatooine in Episode IV, rescued Luke from Cloud City in Episode V, and destroyed the Death Star in Episode VI. It is because of the Millennium Falcon that Luke is able to travel throughout the galaxy and achieve the various other stages of his quest. The magical flight of Luke occurs throughout the Star Wars saga. And although the Millennium Falcon does not ultimately return Luke to society from the heroic journey, the Falcon is the ship which is always linked with Star Wars because it is this ship which allows Luke to complete his heroic quest. It is worth noting that throughout the Star Wars saga the Millennium Falcon is scoffed at by everyone and labeled a "piece of junk." At the final climax however when the Rebellion is mounting a charge against the Death Star, the Millennium Falcon becomes the command ship of battle thereby elevating it from a "piece of junk" to a ship of great importance.

The protagonist of a quest story is unable to complete the journey without the aid of others. The Greek hero Jason, for example, had a group of followers known as the Argonauts who aided the hero on his quest for the Golden Fleece. ${ }^{158}$ Serving the same

${ }^{157}$ Edith Hamilton, Mythology (New York: Little, Brown and Company Publishers, 1998) 161-179.
${ }^{158}$ Edith Hamilton, Mythology (New York: Little, Brown and Company, 1998) 161-179. 
function as the Argonauts, Luke's band included the assistance of Han Solo, Chewbacca, C3PO, R2D2, Lando Calrissian, and Princess Leia. Through the support of these characters Luke is able to survive the heroic journey and achieve his ultimate goal. But these characters are a signficant part of the journey themselves. They are a part of the quest. At some point in many quest stories the hero will require rescuing from a situation he cannot resolve alone and is unable to rely on his band of supporters. At this point in the story, aid comes to the hero not from a source from within the quest itself (i.e. the band of helpers) but instead from outside the heroic journey. Campbell argued that this rescue occurs because society is calling the hero back from the magical state-of-being that is the heroic journey. ${ }^{159}$ Campbell labeled this stage of the journey the "Rescue from Without" because the source of this help is from outside the bubble of the heroic journey. A part of society pierces the shell of the journey and aids the heroic character/s.

In Star Wars the rescue from without stage of the heroic journey occurs in Episode VI when, on the planet moon of Endor, the Rebels are saved from the Empire by the Ewoks. The overriding goal of Episode VI is: destroy the rebuilt Death Star which is being protected by a shield generated from the Endorian Moon. The plan, then, is to have one group of Rebels disable the shield while another group attacks and destroys the Death Star. Han Solo and Princess Leia lead the assault on the shield but are soon captured by the Empire. The mission to disrupt the shield is poised to fail making the situation bleak for the Rebellion. The captured Rebellion is then saved by the native Ewoks who inhabit the forests of the Endorian Moon. The Ewoks then proceed to help conquer the imperial

\footnotetext{
${ }^{159}$ Joseph Campbell, The Hero with a Thousand Faces, (Princeton: Princeton University Press, 1977) 207.
} 
forces located on the Moon and disable the shield protecting the Death Star allowing the Rebel forces a chance to destroy the Death Star. ${ }^{160}$

The Empire is depicted in Star Wars as a technologically superior force that wields the most powerful weapons of the galaxy. The Ewoks in contrast are an Aboriginal hunter/gather culture which uses stone weapons to fight. The Empire is part of the heroic journey of Luke Skywalker because it is the antagonist which Luke is fighting. The Ewoks conversely are a part of the galaxy which has been ignored by both sides of the conflict. They have been untouched by the struggle between the Empire and the Rebellion. They represent the unchanged part of society which is not a part of the heroic journey. The Ewoks rescue of the Rebel forces is the "rescue from without" because it is society calling the hero back from the quest. It is important to remember that while the heroic figure has been secluded from the rest of the world by the quest, the culture to which he belongs continues to exist but for the most part remains static. It is the hero's return which will change society. The Ewoks are the embodiment of the unchanged culture the hero Luke left behind. By saving the Rebellion and aiding in the final achievement of the ultimate goal the Ewoks are the rescue from without scenario Joseph Campbell described in his heroic journey. ${ }^{161}$

Towards the end of a journey the protagonist has realized the ultimate goal of his quest. He has heeded the call of society to return from the quest, but he must overcome one more obstacle before he is granted that return. As it was stated earlier the barriers between the world of the journey and the world of "normal" society are guarded by a

\footnotetext{
${ }^{160}$ Star Wars Episode VI: Return of the Jedi, Dir. Richard Marquand (Fox Searchlight Studios and Lucasfilm Ltd., 1983).

${ }^{161}$ Joseph Campbell, The Hero with a Thousand Faces (Princeton: Princeton University Press, 1977) 207216.
} 
threshold which demarcates both worlds. In order to return from the quest the heroic protagonist, for he is truly a heroic figure at this point, must cross that threshold. Joseph Campbell labeled this stage of the heroic journey "Crossing of the Return Threshold" because it marks the point at which the hero ceases his journey and becomes a part of society once again. ${ }^{162}$

In Star Wars the final obstacle that remains which the heroic Rebellion must overcome to obliterate all traces of the Empire is the destruction of the Death Star. In Episode VI the Emperor dies at the hands of Darth Vader and Luke Skywalker. Darth Vader himself dies and the imperial troops are overthrown by the Ewok and Rebel forces. The destruction of the Death Star will eliminate the remaining imperial threats to the Rebellion. Lando Calrissian, played by Billy Dee Williams, in the Millennium Falcon eliminates this final obstacle by destroying the Death Star. ${ }^{163}$

By achieving the ultimate goal of the quest the protagonist has transformed himself into a hero that has conquered the world of the heroic journey. Reality, Campbell would argue, is divided between the world of the quest/adventure/journey and the world of the more common day-to-day existence. Each sphere represents a different aspect of life and very few people conquer the world of the quest. ${ }^{164}$ The journey the hero has taken represents the trials and tribulations that exist in the world as a whole, consisting of both the world of the quest and the mundane world of the common, and as a completer of

\footnotetext{
${ }^{162}$ Joseph Campbell, The Hero with a Thousand Faces (Princeton: Princeton University Press, 1977) 207.

163 Star Wars Episode VI: Return of the Jedi, Dir. Richard Marquand (Fox Searchlight Studios and Lucasfilm Ltd., 1983).

${ }^{164}$ Joseph Campbell described the differences between the world of the "norm" and the world of the quest as: "The two worlds, the divine and the human, can be pictured only as distinct from each other-different as life and death, as day and night. The hero adventures out of the land we know into darkness; there he accomplishes his adventure, or again is simply lost to us, imprisoned, or in danger; and his return is described as a coming back out of the that yonder zone." Joseph Campbell, The Hero with a Thousand Faces (Princeton: Princeton University Press, 1977) 217.
} 
this journey the hero has become a master of this realm. The hero then proceeds to return to the culture he left behind to undertake the journey and becomes a "Master of the Two Worlds." The two worlds are separated from each other, so very few people ever experience the world of the quest. A master of the two worlds is rare because there are relatively few heroes compared to the rest of society. ${ }^{165}$

In Star Wars hero Luke Skywalker completes the heroic journey to overthrow the Empire and become a Jedi knight. Both of these goals are fully realized by the completion of the Episode VI. The quest Luke set out on when he first answered the call to aid the Rebellion has come to an end and he must re-enter the world of the common leaving behind the world of the quest. One of the final acts that Luke performs is to burn the body of Darth Vader on a funeral pyre before he joins the Rebellion victory celebration. ${ }^{166}$ Burning Darth Vader's body serves multiple symbolic functions in the heroic journey. Firstly it serves as a final atonement with Luke's father. By burning the body of Darth Vader Luke burns away the mask of Darth Vader and allows Anakin Skywalker to be truly free of the villain he had become. The burning of Darth Vader is also a way for Luke to fully exit the world of the quest completely. It is the final act he completes before ending the adventure. Luke set out to become a Jedi like his father, and in burning away Darth Vader he burns away the evil part of his father so that only Anakin remains. And if only Anakin remains, then Luke no longer has any qualms about emulating his father making him a master of the two worlds.

165 Joseph Campbell, The Hero with a Thousand Faces (Princeton: Princeton University Press, 1977) 239237.

${ }^{166}$ Star Wars Episode VI: Return of the Jedi, Dir. Richard Marquand (Fox Searchlight Studios and Lucasfilm Ltd., 1983). 
Star Wars concludes with final resolutions on all complications presented throughout the story. All questions which were raised throughout the course of the story (such as: does the Rebellion win the battle with the empire?) are answered by the conclusion of Episode VI. The problem for many fans of Star Wars, however, is that the universe continues to exist despite the lack of more movies. In the minds of many fans, Luke Skywalker continues to exist after the final credits roll on Episode VI. As a character, Luke wakes up the morning after celebrating the destruction of the Empire and goes on with his life. Once a hero has achieved the goals of the quest and re-entered into society they are given the "Freedom to Live."167 But what does this stage mean?

To Joseph Campbell, the freedom to live stage of the heroic journey is the reward a hero is granted for completing the arduous task of the quest. For some heroic figures that freedom leads to greatness. ${ }^{168}$ For example the Greek hero Hercules was granted the freedom to live after his completion of the twelve labors. This freedom he was granted eventually led to Hercules's ascension to the Greek Pantheon and becoming a god. ${ }^{169}$ For other heroic figures that freedom leads to sorrow. For example the Greek hero Jason was granted the freedom to live after he returned triumphantly with the Golden Fleece. This freedom he was granted eventually led Jason to spurn the mother of his children Medea

\footnotetext{
${ }^{167}$ Joseph Campbell, The Hero with a Thousand Faces (Princeton: Princeton University Press, 1977) 238243.

${ }^{168}$ Joseph Campbell spends a surprisingly short amount of time in his books discussing the "Freedom to Live" stage of the heroic journey. Often there is very little said about a hero after they have returned from the journey except that they will often live "happily ever after" or at least "prosperous ever after." Often the hero will become a king, or sometimes even a demi-god after their return, but those specifics are often only an epilog to the greater quest story. Campbell states: "The hero is the champion of things becoming, not of things become, because he is. 'Before Abraham was, I AM.' He does not mistake apparent changelessness in time for the permanence of Being, nor is he fearful of the next moment... as destroying the permanent with its change." Joseph Campbell, The Hero with a Thousand Faces (Princeton: Princeton University Press, 1977) 243.

${ }^{169}$ Edith Hamilton, Mythology (New York: Little, Brown and Company Publishers, 1998) 242-243.
} 
by marrying another woman causing Medea to murder their children. ${ }^{170}$ Whatever else happens to the hero after the quest though, what remains constant is that the hero is allowed to make his own choices free from the demands of the quest. While on the heroic journey the focus is the ultimate goal and all choices made are in regards to whatever helps achieve this goal. Once the quest if finished the heroic figure is allowed to make his own choices free of this pressure. And just like every other person in society, sometimes those choices lead to greatness and sometimes to ruin. Luke Skywalker earned the freedom to live by his completion of the heroic journey.

${ }^{170}$ Euripides, Euripides I: Four Tragedies- The Medea, Ed. David Grene and Richmond Lattimore (Chicago: Chicago University Press, 1955). 


\section{CHAPTER V}

\section{Historical Influences on Star Wars}

There are of course many different elements and reasons why filmmaker George Lucas shaped his Star Wars saga the way he did and why we as an audience ended up with a Star Wars looking, feeling, and even sounding the way it did. George Lucas has stated in many different interviews that he created Star Wars, in part, as a homage to the serial movies (a film short often shown in conjunction with a feature film) popular in the 1930 s and 40 s while Lucas was growing up. ${ }^{171}$ One of the most popular serial franchises was the Flash Gordon series starring Buster Crabbe as a "space cop" who fought against the evil villains of the universe, which of course is the same basic premise of Star Wars. However, other external forces played a role in the final shaping of the Star Wars story. In his article Star Wars: A Myth for Our Time author Andrew Gordon illustrates how Star Wars is pieced together from a plethora of different sources.

\footnotetext{
${ }^{171}$ George Lucas often talked about how much influence his childhood had on his later life including the inspiration of his movie-making career. Some of the movie serials that had the most influence were a "western" type story that was often set in space. He stated: "I'd always been very fascinated with Buck Roger and Flash Gordon as a child, and I'd seen a lot of serials and they were all very exciting. We were just beginning the Space Age, and it was all very alluring to say, gee, we could build a modern mythology out of this mysterious land that we're about to explore." Mary Henderson, Star Wars, The Magic of Myth (New York: Bantam Spectra Books, Doubleday Dell Publishing Group Inc., 1997) 136.
} 
In an era in which Americans have lost heroes in whom to believe, Lucas has created a myth for our times, fashioned out of bits and pieces of twentieth-century U.S. popular mythology-old movies, science fiction, television, and comic books-but held together at its most basic level by the standard pattern of the adventures of a mythic hero. Star Wars is a masterpiece of synthesis, a triumph of American ingenuity and resourcefulness, demonstrating how the old may be made new again: Lucas has raided the junkyards of our popular culture and rigged a working myth out of scrap. ${ }^{172}$

And while film serials such as The Shadow and Flash Gordon were certainly popular during their day, comic books were becoming equally popular with children of the 1930s and 40s. The "Golden Age of Comic Books" began in 1938 with the birth of the first truly successful superhero named Superman created by Jerry Siegel and Joe Shuster. Comic book companies had experimented briefly with other superhero formats such as the 1934 character Mandrake the Magician who had the power to hypnotize villains with hallucinating images. And while Mandrake the Magician is considered by historians as the first true "super-powered-hero," it was really Superman who spurred comic book stories into the superhero format. Before the birth of Superman comic books were what is predominantly referred to as "hard boiled fiction." This genre of storytelling included westerns, adventure, and crime fighting and were distinguishable by their visual portrayal of violence and sexuality. Stories were no longer simply read but included illustrations by an artist who portrayed the story through pictorial panels. When Siegel and Shuster created Superman they introduced a new type of hero to the public because the hero was no longer merely a lone gunman or a hardened crime fighter but was instead an individual who possessed super human abilities. ${ }^{173}$ Star Wars is a

\footnotetext{
172 Joel Martin and Conrad Ostwalt Jr., Screening the Sacred: Religion, Myth, and Ideology in Popular American Film, "Star Wars: A Myth for Our Time," by Andrew Gordon (Boulder: Westview Press Inc., 1995) 73.

${ }^{173}$ Ron Goulart, The Great American Comic Books (Lincolnwood: Publications International Ltd., 2001) $72-97$.
} 
continuation of these types of serials and comic books because they contain both heroes and villains who possess abilities beyond those of the normal person.

However George Lucas was not solely influenced by comic books, science fiction, and film serials. He was also influenced heavily by history itself. Much of the imagery people have of the American "Old West" comes from a multitude of novellas written during the time period which stylistically depicted the exploits of historic men. It is from these novellas that images such as the "lone gunman," for example, where first written about. As was stated earlier, Star Wars was influenced by classic western stories which depicted "loner" type characters fighting injustice on the untamed frontier. These western type story novellas were often based at least somewhat on actual historical figures and events such as Wyatt Earp, Doc Holiday, and Batt Masterson. The "western" style of storytelling typically would revolve around a character conquering and taming the wild western frontier.

Many of these western stories contain some common mythical elements with Campbell's heroic quest. The weapon of the western gunfighter, for example, would fall under the "supernatural aid" in Campbell's outline of the heroic quest. And like the light saber, the gun used in a western story becomes iconic. The famous "six shooter" or "colt .45 " became synonymous with the western style of storytelling. This western style of storytelling does not include, however, many of the stages a heroic quest story does. The western gunfighter, for example, never leaves the "story realm" and re-enters society. The gunfighter in a western is usually depicted as an outsider who, at the end of the story, "rides off into the sunset" instead of rejoining the culture. The gunfighter never becomes 
a "master of two worlds" or is ever given "the freedom to live" and instead lives within a story that only ends with his death. ${ }^{174}$

On October $4^{\text {th }} 1957$ Soviet Russia launched Sputnik 1 , the first manmade object to achieve Earth orbit. With that event, both the United States and Russia became enthralled in a "space race" with the agenda to be the first country to set foot on the Moon. Before man first expanded out into the cosmos relatively little was actually known about outer space. There were plenty of theories, speculations, and even myths concerned with outer space but no one truly knew what to expect when people started to venture into this colossal unknown. To alleviate our complete lack of knowledge about outer space both the Americans and the Soviets began conducting dozens of missions spanning hundreds of man hours testing and experimenting with the limits of space. As a result of all the attention being placed on the NASA missions, space replaced the west as the new frontier. Shows such as Star Trek and Battlestar Galactica became popular because of the allure that space holds. Unlike the western frontier of the Americas, or even the deep oceans of our world, space is a frontier that literally has no end and can therefore never be completely known. This unknown makes western, mythological, super-heroic stories such as Star Wars so popular with viewing audiences and why George Lucas chose this stage to set his story. ${ }^{175}$

\footnotetext{
${ }^{174}$ Robert St. Clair, Literary Structures, Character Development, and Dramaturgical Scenarios in Framing the Category Novel, (Lewiston: The Edwin Mellen Press, 2004) 265.

${ }^{175}$ George Lucas often spoke of how fascinated and affected he was by the space race of the late 1950s and 1960s. He stated: "I became very fascinated with how we could replace this mythology that drifted out of fashion-the Western. One of the prime issues of mythology was that it was always on the frontier, over the hill. It was always in this mysterious place where anything could happen, so you could deal with metaphor and that sort of thing. And I said, well, the only place we've got left is space-that's the frontier." Mary Henderson, Star Wars, The Magic of Myth (New York: Bantam Spectra Books, Doubleday Dell Publishing Group Inc., 1997) 136.
} 
Other than the space race of the 1960 s, creator George Lucas was also inspired by other historical events. Author Mary Henderson points out in her book Star Wars: The Magic of Myth that Lucas drew on World War II as one of his sources when sculpting the villain within the Star Wars saga.

The trilogy's Galactic Empire was also influenced by real-life cultural concerns, pattering a cross section of images and attitudes from the history surrounding its creation. Lucas was born at the end of World War II and grew up in its aftermath. The Nazi concentration camps revealed all too clearly that humans could inflict the worst possible horror upon other humans, and the use of the atom bomb demonstrated that we could wipe ourselves out... In Star Wars, the Death Star can be viewed as the ultimate nuclear weapon, and the look of the Imperial Army is clearly influenced by the Nazis. ${ }^{176}$

There has been a myriad of theories proposed as to the exact influence of the Galactic Empire but the most predominant one by far is that the Nazi Third Reich played the largest influence on how the Empire is portrayed.

One of the most obvious parallels between the Empire and the Nazis is the sense of uniformity conveyed by both groups. The underlying goal of the Nazi party was to eradicate or suppress all other races other than those of "Arian" blood. In short the Nazis wanted a genetically homogeneous world devoid of diversity. The Galactic Empire of Star Wars is a striking parallel with this goal. All soldiers of the Empire are white. Additionally George Lucas called the foot soldiers of the Galactic Empire "stormtroopers" which is the same name given to the personal elite guard of the Führer Adolf Hitler. $^{177}$

George Lucas hints on a subconscious level at the connection between Nazi Germany through the colors in which he decks the Galactic Empire. The predominant

\footnotetext{
${ }^{176}$ Mary Henderson, Star Wars, The Magic of Myth (New York: Bantam Spectra Books, Doubleday Dell Publishing Group Inc., 1997) 144.

${ }^{177}$ Mary Henderson, Star Wars, The Magic of Myth (New York: Bantam Spectra Books, Doubleday Dell Publishing Group Inc., 1997) 146.
} 
colors of the Empire are white (represented by the stormtroopers), black (seen through Darth Vader), and red (displayed by the personal bodyguards of the Emperor). White, black, and red are the colors of the famous "blood flag" of the Nazi third Reich.

The Empire can be generally viewed as the faceless power that seeks to dominate and control everything. Often referred to in modern colloquialisms as "the man" or "big brother" the Empire is that entity which seeks to extinguish individuality and assert absolute control over everyone. ${ }^{178}$ This bleak cold entity is the enemy George Lucas has his heroes pit themselves against. And there is something relatable about the Empire because people have and continue to fight against that type of evil. The Empire is identifiable and understandable as an evil power because of the source material he drew on from comic-books, science fiction, and history. Drawing on things that people already understand made Star Wars a more accessible story.

${ }^{178}$ Star Wars: The Legacy Revealed, Dir. Kevin Burnes (The History Channel and Lucasfilm Ltd., 2007). 


\section{CHAPTER VI}

\section{Star Wars and Philosophy}

Most of the references within this work thus far illustrate how the "western world" has asserted a profound influence on the story of Star Wars. But there were many eastern influences as well. This eastern influence can be seen most prevalently in writer George Lucas's choices of names for his characters. For example vader is the word for "father" in Dutch. Another example is the character Yoda, whose name is derived from the Sanskrit word yodda meaning "warrior" and the Hebrew word yodea meaning "knows." Both examples illustrate how the names of the characters embody the personality and role of the characters themselves play within the story of Star Wars. Yoda is a warrior whose main character trait is that of a wise figure who has all the answers, while Darth Vader is the father of both Luke and Leia.

One of the most pronounced examples of names embodying the persona of the character comes from Lucas's name for his heroic Jedi knight. The word "jedi" comes from the Japanese word jidaikeki which means "history thing" or "history piece." In film, jidaigeki are the samurai films of the region and indeed in the Star Wars universe the Jedi knights are the embodiment of the Samurai knights of ancient Japan. ${ }^{179}$ George Lucas even stated in an interview that he was heavily influenced by the 1958 Samurai movie The Hidden Fortress, from which he took some story and plot structural

${ }^{179}$ Star Wars: The Legacy Revealed, Dir. Kevin Burnes (The History Channel and Lucasfilm Ltd., 2007). 
elements. ${ }^{180}$ Samurai knights are always depicted in story and myth as a warrior priest class who are both fearsome in battle but also highly disciplined and reflective in life. The swords the Samurai wield are just as recognizable as the light sabers the Jedi's brandish. Also the attire Lucas chose to deck the Jedi knights in was inspired by the robes of the Samurai knighthood. ${ }^{181}$

In addition to this eastern influence found in the depiction of the Jedi knights, other eastern fingerprints can be found when viewing the Star Wars saga as well. There have been a multitude of theories proposed by scholars to what "the Force" in Star Wars actually embodies and what its creational influences are. Some argue that "the Force" is the ever-presence of God in a Christian's life, while others theorize it is akin to the Islamic teaching of spiritual chivalry. But one of the most compelling comparisons is drawn between the Force and the Chinese philosophical idea of ch'i. Author Walter Robinson theorizes in his paper The Far East of Star Wars that the movie saga was not only influenced by the western world, but was also greatly influenced by eastern culture and philosophies. Robinson states:

${ }^{180}$ Star Wars Trilogy, Special Edition, by George Lucas (Fox Searchlight Studios and Lucasfilm Ltd., 1995).

${ }^{181}$ There have been numerous parallels drawn between Star Wars and the eastern cultures (most especially feudal Japan). Mary Henderson states: "Lucas expressed his interest in feudal Japan to artist Ralph McQuarrie when he asked him to come up with the first renderings of the Star Wars look and even offered images of samurai warriors for inspiration...Lucas told McQuarrie that he wanted Darth Vader to look like 'a dark lord riding on the wind' with black flowing robes, a large helmet like that of the Japanese samurai, and a silk mask covering his face." Mary Henderson, Star Wars, The Magic of Myth (New York: Bantam Spectra Books, Doubleday Dell Publishing Group inc., 1997) 186-189. 
The 'Force' is central to the Star Wars mythology. In A New Hope Obi-Wan Kenobi describes it as 'an energy field created by all living things. It surrounds us and penetrates us. It binds the galaxy together.' This is an extremely good description of what is known in Chinese as 'ch'i,' or in Japanese as 'ki.' In the Star Wars galaxy, the Jedi use the Force in their fighting arts... In the martial arts of the Far East, ch'i is cultivated to give special fighting advantage over someone who relies only on physical strength. Eastern philosophy, most especially philosophical Taoism and Zen Buddhism, plays a major role in the Star Wars mythology. ${ }^{182}$

One of the fundamental tenets of Dao philosophy is the idea of the yin and yang.

The Dao understanding of ch'i teaches that all energy is created as either good (yin) or evil (yang). It is only through finding a balance with the yin and the yang of life that people will be able to find peace within themselves. Take note that Dao teachings do not seek to destroy the yang side of energy, but instead seek a balance with it. In his book Experiencing the World's Religions, author Michael Molloy describes the yin and yang as opposite, but also complementary. He states:

After about 1000 B.C.E the Chinese commonly thought that the universe expressed itself in opposite but complementary principles: light and dark, day and night, hot and cold, sky and earth, summer and winter. The list was virtually infinite...these principles \{yin and yang\} are not the same as good and evil. Yang is not expected to win over the force of yin, or vice versa; rather, the ideal is a dynamic balance between the forces. ${ }^{183}$

The goal of seeking a balance with both the light and the dark is precisely the philosophy of the Jedi knighthood. Not once do Jedi teachings pronounce a desire to wipe out the dark side of the Force (represented by the Sith) but instead express a desire to balance themselves with the dark.

Other philosophical issues emerge when viewing the Star Wars galaxy, such as the moral dilemma of slavery thrust upon the very sentient androids, or the tyranny

\footnotetext{
${ }^{182}$ Kevin Decker and Jason Eberl, Star Wars and Philosophy: More Powerful Than You Can Possibly Imagine, "The Far East of Star Wars," by Walter Robinson (Chicago: Open Court Publishers, 2005) 29.

${ }^{183}$ Michael Molloy, Experiencing the World's Religions: Tradition, Challenge, and Change (New York: McGraw-Hill Publishers, 2010) 217.
} 
inherent in a dictatorship which functions through fear. But one of the most intriguing philosophical issues generated by the Star Wars movie saga is the philosophical and religious concept of fate and/or destiny.

Arguably one of the most profound religious questions humans ask is on the topic of fate. Christian scholars and lay people alike have been asking for centuries why God allows bad things to happen to good people. ${ }^{184}$ One of the answers generated by this question is that it was simply a pre-determined fate that allows for evil deeds to befall devout faithful people. "It was simply meant to be" is often the response given. "But if God knew ahead of time that something awful was about to befall his loyal and devout followers, wouldn't he intercede?" is typically the response to this line of reasoning. Christianity is a religion with an omnipotent ever present deity, and many believe that everything that does happen is exactly what should happen because it is the will of God. The idea that everyone has a fate or a destiny has been a part of Christian thinking since the begining. "God has a plan for me," "It's all part of the grand plan," "Trust that God knows what he is doing" are common beliefs among Christian practitioners.

In 524, the Italian philosopher Boethius stated in his work Consolation of Philosophy that mankind was not shackled to one fate but instead argued that since God exists outside of time that he perceived every moment of eternity simultaneously. The result was that although God did know what the future held, yet he did not "cause" that future to occur. Instead people were subject to a free will that allowed them to make both good and bad decisions. Consolation of Philosophy allowed for the randomness of people and the result became a future which was unknowable to anyone other than the

\footnotetext{
${ }^{184}$ As an experiment I googled the question: "Why does God let bad things happen to good people?" with the result of $5,980,000$ web results.
} 
divine. The philosophies of Boethius became popular in many western forms of Christianity because of these ideas. ${ }^{185}$

Fate and destiny are concepts which are also breached in the saga of Star Wars. Multiple prophecies and premonitions occur throughout the Star Wars movies. There is, for example, the prophecy of the "Chosen One" who will bring balance to the Force found in Episode I. ${ }^{186}$ There is also the premonition of Luke while training on Degoba about his friends being tortured by Darth Vader. ${ }^{187}$ There are also, however, the premonitions of the Emperor in Episode VI where he states "everything is proceeding precisely as I have foreseen."188 The Emperor goes on to reveal that he has already foreseen the destruction of the Rebellion and his own victory. This statement brings up a philosophical problem because as we know the Emperor was incorrect. He was not victorious and he did not defeat the Rebellion. In his paper "You Cannot Escape Destiny (Or Can You)?" author Jason T. Eberel argues that when dealing with the concepts of fate and destiny, the question really is concerning the idea of causality. Using Aristotelian philosophy, Eberel looks at the issue of causality within the Star Wars movies. Aristotle's famously argued that if someone stated 'there is going to be a sea-battle today" that person may at any given time be right or wrong. Eberel applies this philosophy to Star Wars and states:

\footnotetext{
${ }^{185}$ Anicius Manilus Severinus Boethius, The Consolation of Philosophy, Trans. H.R. James (Oxford: Elliot Stock Printing, 1897).

${ }^{186}$ Star Wars Episode I: The Phantom Menace, Dir. George Lucas (Fox Searchlight Studios and Lucasfilm Ltd., 1999).

187 Star Wars Episode V: The Empire Strikes Back, Dir. Irvin Kershner (Fox Searchlight Studios and Lucasfilm Ltd., 1980).

${ }^{188}$ Star Wars Episode VI: Return of the Jedi, Dir. Richard Marquand (Fox Searchlight Studios and Lucasfilm Ltd., 1983).
} 
If it was true at the time of The Phantom Menace that Obi-Wan would later die at Vader's hands in $A$ New Hope, then Obi-Wan must die at the time. But Obi-Wan ceased fighting, held up his lightsaber, and allowed Vader to kill him... One way to answer this apparent fatalism is by noting... where the chain of causality starts. If the proposition 'Obi-Wan will die at Vader's hands' is true thirty-plus years before it happens, it doesn't necessarily cause Obi-Wan's death. Rather, ObiWan's choice to allow Vader to cut him down is what makes the proposition true and also makes the proposition 'Obi-Wan will live to see the Emperor defeated' false. Another way is to deny, as Aristotle does, that future-contingent propositions have any truth value whatsoever--they are neither true nor false when they are spoken. Such propositions become true or false only when the event to which they refer occurs or fails to occur. ${ }^{189}$

The concepts of fate and destiny, which have long been questions concerned with philosophy and religion became a part of the structure of the Star Wars storyline.

${ }^{189}$ Kevin Decker and Jason Eberl, Star Wars And Philosophy, "You Cannot Escape Your Destiny" (Or Can You?): Freedom and Predistination in the Skywalker Family," Jason T. Eberl (Chicago: Open Court Publishers) 10-11. 


\section{CHAPTER VII}

\section{THE MYTHICAL ELEMENTS IN STAR WARS}

Other interesting parallels can be found in Star Wars beyond what Joseph Campbell described in his heroic journey. When Campbell was describing the journey a heroic figure will take in a quest story, his outline was not simply a "connect the dots" rundown of what the character should do next in the story. Campbell's work illustrated many mythical elements beyond the various stages of the story. For example, Campbell argued that many myth stories contain an oracle that the hero will consult with during their quest. The Greek army, for example, consulted the Oracle of Delphi before they went to war with Troy in Homer's Iliad. The Greeks questioned the Oracle on how to get favorable winds for their voyage to Troy. The Oracle's answer eventually led the Greek army to sacrifice Agamemnon's daughter Iphigenia to appease the gods which gave them the winds they needed. ${ }^{190}$ And while this consultation with the Oracle is not a stage in Campbell's heroic journey, it is important because it is a necessary element of the story. If the Greeks do not consult the Oracle, then they cannot get favorable winds, and therefore cannot go to Troy which means there is no heroic journey story. All heroic quest stories contain plot devises which are not stages of the journey but are still important to the story. Many of these common mythical elements can be found in the works of both Campbell and Lucas.

${ }^{190}$ Homer, The Iliad, Trans. by W.H.D. Rouse (New York: Penguin Books Group, 1938). 


\begin{tabular}{|l|l|}
\hline \multicolumn{2}{|c|}{ Common Mythical Elements } \\
\hline Campbell & Lucas \\
\hline Two worlds (mundane and special) & Planetside vs the Death Star \\
\hline The Mentor & Obi-Wan Kenobi \\
\hline The Oracle & Yoda \\
\hline The Prophecy & Anakin will overthrow the Emperor \\
\hline Failed hero & Biggs \\
\hline Wearing Enemy's Skin & Luke and Han wear storm trooper outfits \\
\hline $\begin{array}{l}\text { Shapeshifter (the hero isn't sure if he can } \\
\text { trust this character) }\end{array}$ & Han Solo \\
\hline Animal familiar & R2-D2, Chewbacca \\
\hline
\end{tabular}

In his research of the various myths found throughout human culture, Campbell distinguished between the world of the mundane existence, which predominates most of life, and the special world of the mythological. And while the two worlds do coexist, they are distinct separate spheres of existence. The common person experiences only the world of the mundane, while the heroic figure will also encounter the special world of the mythological. Luke Skywalker is raised on the planet Tatooine, an unremarkable desert planet which Luke describes in Episode IV as the planet farthest from the bright center of the galaxy. ${ }^{191}$ Luke's life, as a farmer, consists of routine chores which keep his family's moisture farm (on the arid planet Tatooine waster is harvested out of the air and used like a crop) operational. Luke's guardian, Uncle Owen Lars, represents this world of the mundane routine. The character Owen Lars appears in three different Star Wars movies (Episodes IV, II, and III) and all three scenes take place on his farm, which he inherited from his father. As the icon of this mundane world Uncle Owen seeks to keep Luke from venturing into the special world of the mythological. Uncle Owen acts as an anchor

${ }^{191}$ Star Wars Episode IV: A New Hope, Dir. George Lucas (Fox Searchlight Studios and Lucasfilm Ltd., 1977). 
which strives to keep Luke within the normal day-to-day world of the mundane and it is only after his death that Luke ventures into the world of the mythological.

Once Luke Skywalker leaves his Uncle's farm and the mundane world, every scene thereafter takes place in the world of myth. Once entered, Luke is exposed to people, places, situations, and technology that he would never have encountered within the world of the mundane and so everything is, in a sense, special from the perspective of Luke. The Imperial Death Star, however, is representative of this special mythological world. The Death Star is the quintessential opposite of the family farm on Tatooine. While the farm on Tatooine is an agricultural comparatively low-tech operation, the Death Star is the culmination of all the technology this galaxy has to offer. Upon its completion the Death Star is not only the most powerful weapon ever built, capable of destroying planets which is beyond the power of the entire Imperial Fleet, but is also the largest space station ever constructed. Residing in the mythological world of the special, the Death Star is a unique representation of this new realm Luke finds himself in.

Filmmaker George Lucas used this contrast between the two worlds to illustrate the dramatic differences between the worlds as well as depicting the diversity contained within this fantasy realm. For example Lucas created a technologically superior world that still depends on farming. By having Luke grow up on a farm Lucas not only creates a background for his main character but he also illustrates to the audience that Star Wars is a galaxy which has a lot in common with our own culture. Star Wars is not, for example, like the world of Star Trek which has technology that can produce food at the 
touch of the button. ${ }^{192}$ In addition, while Star Wars is a galaxy which contains a vast array of superior machinery it still contains a staggered cultural hierarchy in which not all people have complete access to this technology. Everyone in the Star Wars galaxy does not, for example, have a personal servant droid that performs all menial tasks. This distinction is important to make for the George Lucas story of Star Wars because it will be the technologically inferior Rebellion/Ewoks who defeat the technologically reliant Empire. Lucas juxtaposes the special world of technology/mythology represented by the Death Star with the mundane world of planet side Tatooine which is the existence Luke has known his entire life.

Once Luke Skywalker leaves the safe world of the day-to-day and enters the special world of the mythological he instantly becomes an outsider because he is unaccustomed to this new world. During this first Act of the Star Wars saga Luke is depicted as an innocent who lacks the savvy needed to survive the harsh galaxy. The only sure thing Luke knows at this point in the story is that he wants to become a Jedi knight like his father, and that R2D2 must be delivered to the Rebellion. The mentor character serves as a guide to the heroic character and imparts upon the protagonist the skills and information needed to undertake the heroic journey. In Star Wars the role of the mentor character is filled by Obi-wan Kenobi.

Campbell argues that the mentor character is a vital part of the heroic journey myth because it is often the mentor who starts the transformation of the heroic figure. Campbell states:

\footnotetext{
${ }^{192}$ When talking about the comparison between the Star Trek and Star Wars I refer to the later part of the Star Trek franchise created by Gene Roddenberry. That is to say, Star Trek The Original Series with Captain Kirk does not have "replicator" technology while Star Trek The Next Generation, Star Trek Deep Space Nine, and Star Trek Voyager all have the ability to convert energy into food.
} 
In fairy lore it may be some little fellow of the wood, some wizard, hermit, shepherd, or smith, who appears, to supply the amulets and advice that the hero will require. The higher mythologies develop the role in the great figure of the guide, the teacher, the ferryman, the conductor of souls to the afterworld...Protective and dangerous, motherly and fatherly at the same time, this supernatural principle of guardianship and direction unites in itself all the ambiguities of the unconscious - thus signifying the support of our conscious personality by that other, larger system, but also the inscrutability of the guide that we are following, to the peril of all our rational ends. ${ }^{193}$

As stated earlier, the heroic journey is designed to take a common character and turn him into a heroic character. The heroic journey will shape the protagonist into the heroic figure and it is the mentor who begins that shaping process. In Greek mythology the mentor character is typically thought of as Chiron who trained the great hero Achilles. ${ }^{194}$ But the mentor also serves another function beyond the straight forward training of the heroic figure. It is the job of the mentor to give the hero an idea, a vision that cannot be seen without the aid of this character. ${ }^{195}$ In Star Wars, Obi-wan Kenobi allows Luke to envision a galaxy in which the Empire has been overthrown. Because of the teachings of Obi-wan, Luke believes that the Rebellion is not a hopeless cause. Obi-wan is the mentor of the Star Wars universe because he not only taught Luke, but his father Anakin as well.

In the previous section on the mythological structure of Star Wars, it was argued that Yoda shares the role of the mentor within the Star Wars mythology. And while that is certainly true, Yoda also serves as another archetype within the Joseph Campbell structure of mythology. In myth, there is often a character which exudes a supernatural knowledge and wisdom which the hero will often consult in order to help steer them

${ }^{193}$ Joseph Campbell, The Hero with a Thousand Faces (Princeton: Princeton University Press, 1973) 7273.

194 The word "mentor" comes from Homer's character Mentor from The Odyssey who was a type of surrogate father for Odysseus' son Telemachus. However, the most shining example of the mentor character in Greek mythology is the centaur Chiron. Edith Hamilton, Mythology (New York: Little, Brown and Company Publishers, 1998) 46.

${ }^{195}$ Star Wars: The Legacy Revealed, Dir. Kevin Burnes (The History Channel and Lucasfilm Ltd., 2007). 
towards achieving the ultimate goal of their quest. Although it is often the mentor who will initially set the hero upon the path of the heroic journey, the oracle will be consulted along the way to help continue to guide the hero on his quest. In the ancient world an oracle was typically a holy place of worship which people would journey to in order to seek advice on an array of subjects. The most celebrated oracle of the ancient world was the Greek oracle of Delphi. Delphi was said to be the exact center of the world, and for hundreds of years people from all over the ancient world would make a pilgrimage to a site on the side of a mountain some 100 miles northwest of Athens. Once there, petitioners would be given guidance in the form of a prophecy. ${ }^{196}$ Although recent research by John Hale at the University of Louisville has revealed the presence of methane gas at the site that could explain the altered states the priestesses, known as Pythia, would deliver their prophecies in, to the people of the time the oracle possessed supernatural information about the ancient world. ${ }^{197}$ When the Greeks journeyed to the Oracle of Delphi and asked for a prophecy on how to defeat the Trojans, the Oracle responded "The answer lies in wooden walls," which the Greeks took to mean the famed Trojan Horse. When Alexander the Great journeyed to the Oracle and asked "Who am I?" the Oracle replied "You my boy are unbeatable." So to the people of the ancient world the oracles were a place of supreme wisdom, knowledge, and guidance.

To Luke Skywalker, finding Yoda is very much like making a pilgrimage to the Oracle at Delphi. Yoda resides on the planet Degoba which is a remote planet Luke journeys to in Episode VI at the behest of Obi-wan Kenobi with the intention of completing his Jedi training. Once there, Luke undertakes exercises and tests which

${ }^{196}$ Edith Hamilton, Mythology (New York: Little, Brown and Company Publishers, 1998).
${ }_{197}$ In Search of History-Oracle at Delphi (History Channel), (A\&E Home Video, 2006). 
mold him into a Jedi knight. The character Yoda possesses an extensive, somewhat supernatural knowledge about Luke for someone who seemingly lives in a backwater planet and Luke, at first, dismisses Yoda as insignificant. ${ }^{198}$ As a Jedi Master, Yoda instructs Luke in the ways of the Jedi knight and it is the knowledge given to Luke by Yoda which allows this heroic character to achieve the goal of the heroic journey.

George Lucas depicts the character Yoda as a solitary figure who possesses knowledge the other woefully ignorant characters do not. When Luke and Yoda first meet, Yoda hints that he is more than what he at first seems by telling Luke about his father. When Obi-wan laments that Luke Skywalker is the last hope of the Jedi, Yoda responds that there is an alternative to Luke. It is made clear to the audience that Yoda is a character who possesses the most extensive knowledge within the Star Wars realm. In essence, Yoda is the character who exemplifies what playwrights often refer to as Sophoclean Irony. Sophoclean Irony is named after the Greek playwright Sophocles who used a plot devise in which the audience knew important information about what is happening on stage that the characters do not. For example when Oedipus marries Jocasta, the audience is aware that the newly married couple is mother and son but the characters themselves do not. ${ }^{199}$ Yoda exemplifies this mode of storytelling because he is the only character in the Star Wars universe that understands how all the separate pieces of the saga fit together. In Star Wars Yoda is the character that has all the information, much like other prophetic characters in literature. In Greek mythology, the most renowned prophetic character was Tiresias of Thebes. Tiresias appears in multiple stories including The Theban Plays of Sophocles (c. 430 b.c.e.) and Homers Odyssey

\footnotetext{
198 Star Wars Episode V: The Empire Strikes Back, Dir. Irvin Kershner (Fox Searchlight Studios and Lucasfilm Ltd., 1980).

${ }^{199}$ Sophocles, The Theban Plays, Trans. by David Grene (Chicago: Chicago University Press, 1991).
} 
(written sometime in the late seventh century b.c.e.). Tiresias is a blind prophet who, for example, knows Oedipus killed his father, married his mother and is the cause of the plague infecting Thebes. ${ }^{200}$ As the supreme possessor of knowledge in the Star Wars universe, Yoda is simply another incarnation of the prophetic oracle character within the myth structure.

To the people of the ancient world, and even today, prophecies were an integral aspect of existence and by discerning prophecies one could unlock the secrets of the universe. Prophets such as the sixteenth century French apothecary Nostradamus made grand predications about future events that many people believed. Prophecies are also common in many religions that speak of signs that will herald certain events. Many people believe, for example, that decrypting the ancient Christian Bible will illuminate the date of the prophesized Apocalypse (also referred to as the "end of times" in many religions). And this trend of discerning the future has continued into modern times with Tarot Cards, Ouija Boards, and even Magic Eight Balls which are all "tools" designed to help a person predict future events. Another example of current prophecy would be a modern newspaper, a reputable source of information, but which also publishes horoscopes that thousands of readers look to daily for at least a small measure of guiding help. Prophecies have always been an important aspect of mythology and the heroic tale, and as a modern re-telling of myth Star Wars does contain a certain amount of prophecy.

Campbell saw prophecy within myth as a signpost designed to help the protagonist change and grow into the hero he was always meant to become. When the Greeks were under siege from the Persians, for example, King Leonidas of Sparta was told by the Oracle of Delphi that in order for Greece to remain independent that he would

\footnotetext{
${ }^{200}$ Sophocles, The Theban Ploys, Trans. David Grene (Chicago: Chicago University Press, 1991).
} 
have to sacrifice himself defending his home. The king subsequently led a group of Greeks to fight the invading Persians which became the famous last stand of the 300 . It was hearing the prophecy that allowed King Leonidas to become the savior of Greece and the martyr he was "destined" to become. ${ }^{201}$

In Star Wars, the most proficient prophecy tells of a figure that will rise up and bring balance to the Force. It is never made clear who proclaimed this prophecy or when, but the figure of prophecy was referred to by the Jedi as the "chosen one." In Episode I, while on the distant planet Tatooine, Jedi Master Qui-Gon Jinn located the chosen one Anakin Skywalker. As was previously discussed, Anakin is labeled "special" early on in the Star Wars saga. Anakin's ability to use the Force, his miraculous birth, and his high midichlorian count are all evidence Qui-Gon uses to determine Anakin is the Jedi chosen one spoken of in prophecy. ${ }^{202}$ And as with other prophecies contained in legend, how Anakin is to go about bringing balance to the Force is not revealed and so it is a disturbing occurrence when Anakin switches his allegiance to the dark side of the Force. In Episode III Anakin's mentor and teacher Obi-wan Kenobi states: "You were the chosen one. You were supposed to destroy the darkness, not join it." ${ }^{203}$ The Jedi knights had placed a lot of emphasis in the prophecies of the chosen one and were relying on those prophecies to guide them to a balancing of the Force; so for their champion to turn to evil was a blow that resulted in the near annihilation of the Jedi order. By the closing

\footnotetext{
${ }^{201}$ The actual wording of the prophecy of the Oracle of Delphi was that if the Greeks were to win, then a king of Sparta would have to die. Spartan law actually dictated that there be two kings who ruled simultaneously. Leotychides was the second king of Sparta along with Leonidus, and so technically the prophecy could have referred to either one. But since Leonidus was the one who led Spartan troops against the Persians, he was fully aware that the prophecy was indeed speaking of him. Rise and Fall of the Spartans, Dir. John Jopson and Patrick Taulère (A\&E Home Video Studios, 2002).

${ }^{202}$ Star Wars Episode I: The Phantom Menace, Dir. George Lucas (Fox Searchlight Studios and Lucasfilm Ltd., 1999).

${ }^{203}$ Star Wars Episode III: Revenge of the Sith. Dir. George Lucas (Fox Searchlight Studios and Lucasfilm Ltd., 2005).
} 
of Episode III the Jedi knights have been reduced to two living members, the villain Emperor is in complete control of the government, and the Jedi champion Anakin has become the evil Darth Vader. From the perspective of the Jedi knights, it would seem that their prophecies were either wrong, or they had selected the chosen one incorrectly.

Literature is replete with examples of characters' efforts to escape a disturbing or unwanted prediction. Oedipus, for example, was told growing up that he was destined to kill his father and marry his mother. Wishing to escape that fate Oedipus distanced himself from the only parents he ever knew. Not knowing he was adopted, that decision to leave caused him to encounter his birth parents. ${ }^{204}$ The prophecy within Star Wars therefore is inescapable, one which Anakin fulfills in Episode VI when he kills the Emperor and brings balance back to the Force. ${ }^{205}$

Lucas used prophecy within the Star Wars saga as a storytelling device that further allowed audiences to understand that there is a vast power at work within the Star Wars galaxy. A prophecy allowed Lucas to bring up the subject of religion without being overt. The overall power within the Star Wars universe is the Force which is in and of itself a facet of religiosity. By adding a prediction to the religious ideas the Force conjures in the minds of the audience, Lucas reinforces the ideas of destiny, and even faith. Destiny and faith give audiences hope to cling to no matter how bleak the story becomes for the characters of the Star Wars galaxy. If prophecy, which is real in the Star Wars mythos, tells of a day when the Force will come into balance then audiences can believe that everything will be as it should by the end of the story. This feeling of hope is one of the greatest plot elements used in both the Star Wars movies and other

\footnotetext{
${ }^{204}$ Sophocles, The Theban Plays, Trans. David Grene (Chicago: University of Chicago Press, 1991).

${ }^{205}$ Star Wars Episode VI: Return of the Jedi, Dir. Richard Marquand (Fox Searchlight Studios and Lucasfilm Ltd., 1983).
} 
mythological stories. The feeling of hope is a common goal in many mythological stories because they all depict how great and extraordinary a person can be.

Another goal of the mythological experience is to give members of a culture an iconic example of the characteristics each society deems important. Hercules is one of the greatest heroes to the people of ancient Sparta because of his strength, which is a trait the Spartan people hold as important. ${ }^{206}$ Our own culture, for example, has one of our founding fathers confessing to a crime by saying "I cannot tell a lie." George Washington's honesty in this myth says something about the country America wants to be. The heroes of every culture's myths are people who rose above the average and ascended to become something more. But no matter how high a hero's star may rise, there is no example of a protagonist completing the heroic journey without the aid of helpers throughout the story of their quest. And because of the role these aids play in helping the hero accomplish his goals, the helper characters as well become something more than common. And while these helper characters' star may never rise as high as the heroes themselves, the aids are dealt with reverence because of the role they serve within the heroic journey. Mythology abounds with examples of helper characters who achieve some small form of heroism because of their aid to the heroes of myth. The cohorts of the heroic Greek Jason, for example, became known as the Argonaughts. Robin Hood had his band of Merry Men, Frodo had his Fellowship of the Ring, and even Dorothy Gale had a menagerie of helpers when she journeyed through the land of OZ. As aids to the heroic character, these helper characters often make it so the hero can achieve his ultimate goal.

\footnotetext{
206 There are mythological stories surrounding the founding of Sparta, most of which include Hercules as being the founder of Spartan society. Rise and Fall of the Spartans, Dir. John Jopson and Patrick Taulère (A\&E Home Video Studios, 2002).
} 
Star Wars, as mythology, is filled with heuristic characters that are heroic figures in their own right. Han Solo, Obi-wan Kenobi, Princess Leia, and even the droids all can be thought of as "demiheroes" because of the role they played in aiding the heroic characters of the Star Wars mythology in achieving the heroic journey. These characters achieved the rank of "beyond common" because they each fulfilled their role as helpers and achieved their ultimate goal.

But as with all mythology, for every star that rises, there are more that fall. It is important to understand that not every heroic character has a happy ending. In Greek mythology the hero Orpheus, one of Jason's Argonaughts, exemplifies a hero whose story does not end "happily ever after." The goal of Orpheus is to rescue his wife Eurydice from the afterlife which he very nearly achieves before he breaks one of the conditions of her release. ${ }^{207}$ Such examples of fallen heroes also extend to the helper characters contained with myth. The ill-fated crews of Odysseus, for instance, were turned into animals by the witch Circe when their boat wandered too close to her shores. ${ }^{208}$ These fallen heroic characters, while not as successful as the others, are still a vital part of myth because they demonstrate how the goal of every undertaking is not always ultimately realized. One of the purposes of myth is to serve as an allegory for the world in which people live. Some myths explain why the world is a certain way. Often myths serve as an exemplar for what people should aspire to. But the fallen hero myths illustrate how people can strive for something, and still fall short of achieving their goals.

\footnotetext{
${ }^{207}$ Eurydice was in the afterlife when her husband Orpheus bargained for her life from the god Hades for a song. Hades granted Orpheus his wife back on the condition that he lead her out of the underworld with her following behind. The catch was that Orpheus was not allowed to look at Eurydice until they were out of the underworld, a condition he faltered at the last possible moment just before the couple exited back into the land of the living. Edith Hamilton, Mythology (New York: Little, Brown and Company Publishers, 1998) 138-142.

${ }^{208}$ Homer, The Odyssey Trans. W.H.D. Rouse (New York: Penguin Books Group, 1937).
} 
In the realm of Star Wars no character personifies the fallen hero greater than Luke Skywalker's friend Biggs Darklighter. There is very little back story devoted to the character Biggs and he only appears in Episode IV. However, we do know that Biggs is from the planet Tatooine and Luke seems to look up to Biggs as a type of surrogate big brother. When the Rebellion is mounting an attack on the first Death Star, Luke's squadron commander has doubts about the very inexperienced Luke until Biggs assures the commander that Luke can handle himself. The character Biggs is mentioned very early on in Episode IV as Luke uses him as an example of why he wants to leave Tatooine and go to the academy. With the way Luke looks up to Biggs, and him being mentioned so prominently by Luke, Lucas sets Biggs up as someone more than just a side background character. As a member of the Rebellion, the heroic goal of Biggs is the same as Luke's: the overthrowing of the Galactic Empire. This goal is never realized within Biggs's lifetime, however, because he is killed by Darth Vader during the attack on the Death Star. ${ }^{209}$

Biggs becomes a martyr for his cause through his death, and while the goal of his heroic Quest goes unfulfilled within his lifetime, it gets carried on by the rest of the Rebellion such as Luke, Leia, Han, Chewbacca, the droids... which is a goal they eventually accomplish. Falling short of his goal does not mean Biggs Darklighter is not a hero, it simply means he is a failed hero. In mythology the heroic journey is a perilous undertaking that is completed by very few characters so in a sense many of the heroic characters within myth stories are failed heroes.

${ }^{209}$ Star Wars Episode IV: A New Hope, Dir. George Lucas (Fox Searchlight Studios and Lucasfilm Ltd., 1977). 
The heroic journey is designed as a near impossible gauntlet of obstacles intended to force the protagonist to change and become something new. In order to overcome these obstacles and continue forward with the heroic journey, the hero must often perform unpleasant and out of the ordinary tasks. One such task is described by author Joseph Campbell as "wearing [an] enemy's skin" in which the hero will disguise himself as the opposing force and sneak behind enemy lines. A modern example can be found in the 1939 movie The Wizard of $O z$ where the Scarecrow, Lion, and Tinman dress up as the Witch's soldiers in order to rescue Dorothy. ${ }^{210}$

Mythologically this element serves to illustrate that the hero is more than sheer brute force but does indeed posses a cunning side. Because the heroic journey is such a treacherous undertaking, emphasis is often placed on the hero's physical strength and it is only by adding additional elements such as wearing an enemy's skin that the hero is allowed to showcase his intellectual prowess as well. The true master of the heroic journey will be a character who has mastered all the obstacles the quest has forced him to overcome which are both physical and mental. By having Luke Skywalker "wear his enemy's skin" Lucas is adding another level to Skywalker and making him a deeper, richer heroic character.

Luke is not alone in assuming the guise of his enemy by wearing their skin. In Episode IV Luke does not don the uniform of a Stormtrooper alone. Han Solo also shares in this Star Wars mythical element. What then does that say about the character Han Solo? He shares these mythological elements with the heroic figure Luke Skywalker so does that make him as important as the protagonist mythologically? In previous sections Han Solo was discussed because he fulfills the roles of Carl Jung's archetype of

${ }^{210}$ The Wizard of OZ, Dir. Victor Fleming (Metro-Goldwyn-Mayer Studios, 1939). 
the trickster, and Joseph Campbell's amalgam of the guardian avatar. When a character fulfills many different roles it is hard to pinpoint how we as the audience are supposed to feel and react towards this ever-shifting character. And that is exactly how George Lucas wishes audiences to feel when thinking about Han Solo because that character is so much of a question mark throughout the Star Wars Saga and especially in the first parts. Solo makes it clear right from the beginning that he is going to pursue whichever course of action is most advantageous to him, which makes it very hard for audiences to completely trust his actions. Princess Leia fights for the Rebellion and is willing to sacrifice in order to achieve the goals of her cause, which makes her a selfless character. Luke Skywalker strives to become a Jedi knight. Jedi are the protectors of the galaxy, which makes Luke a selfless character. Audiences therefore know that Luke and Leia's motives are for the greater good and can therefore anticipate their actions because the audiences know they will take whichever course is most advantageous for the Rebellion and the galaxy as a whole. Han Solo is a different type of character from both Luke and Leia because of his selfish motivations. It is because of these selfish motivations that the other characters of Star Wars hesitate to fully trust and endorse Solo. Is he truly a member of our Rebellion and can he be trusted to do whatever is in the best interest of our goals?

As the story of Star Wars progresses the allegiance of Han Solo shifts from a selfcentered agenda to a more self sacrificing character. In essence the character Solo shifts from one persona to another, thus earning him the label of a shape shifter in the mythological realm. In mythological terms, shape shifting characters often meant characters whose physical appearance would change in addition to their personality 
characteristics. A shape shifting character in myth was a character who was not to be fully trusted because his identity was such a fluid concept. An example of a shape shifting character occurs in Arthurian myth when the sorcerer Merlin changed the physical characteristics of King Uther Pendrag so that he could take the place of the Duke of Cornwall and bed the Lady Igraine. In legend, while King Uther was never viewed as an evil character, he was also never viewed as a particularly good character either. Instead Uther is a character who is somewhere in between partially because of his dishonorable actions in deceiving the Lady Igraine who was married to the Duke of Cornwall. ${ }^{211}$ And just like Uther, Han Solo will often take selfish actions because those actions will get him what he wants.

Solo has redeeming qualities as well. Solo saved Luke's life from Darth Vader in Episode IV allowing Luke to destroy the Death Star. Solo again saved Luke's life in Episode V when Luke was freezing to death on Hoth, while again in Episode VI Solo volunteers to play a vital role in the Rebellion's assault on the Empire. Despite his negative traits, Han Solo does display redeeming actions and these two opposing viewpoints, selfish vs. selfless, make him a shape shifting character within the mythological realm of Star Wars.

While audiences and Star Wars characters alike try to decide exactly what to think about Han Solo, one character shows absolute devotion and allegiance to Solo throughout the entire saga. Chewbacca serves as the first mate and devoted sidekick aboard the Solo captained Millennium Falcon. Mythologically, the character Chewbacca is the counterpart to Robin Hood's Merry Men, or Jason's Argonaughts because he is a

211 Thomas Malory, Le Morte D'Arthur: King Arthur and of his Noble Knights of the Round Table (London: Simon \& Brown Publishers, 2011). 
helper character who functions as support to the hero's goals. Helper characters were discussed in the earlier section about the parallels found between George Lucas's Star Wars and Joseph Campbell's heroic journey though Chewbacca serves another function within the Campbell mythological spectrum as an animal familiar.

In myth, animal familiars are wild beasts who aid the hero throughout the journey. Most often the job of these animal familiars is to do those tasks which are beyond the ability of the hero. If a hero cannot fly, for example, then an animal familiar may step in to fulfill that need. In myth, the counterpart to the Chewbacca animal familiar would be the flying horse Pegasus. The function of Pegasus in myth is to take other heroes, such as Bellerophon and in some legends Perseus, where the hero needs to go. ${ }^{212}$ As first mate of the Millennium Falcon Chewbacca serves the exact same function as he ferries the heroes to their desired destinations.

Chewbacca is the ultimate faithful dog who follows his master, in his case Han Solo, wherever he leads. In fact Lucas based the character Chewbacca on his own Alaskan malamute Indiana. As a further homage to his dog, Lucas designed the Wookie language to be canine like and to be understood only by Han Solo himself and C3PO (who speaks over a million different languages). ${ }^{213}$ So the label of an animal familiar is more apropos because the character himself was based on a companion animal to begin with.

Chewbacca does not stand alone as the sole animal familiar within the Star Wars universe because he shares the title with the droid R2D2. R2D2 is a service droid whose main task is to operate and communicate with other computers. $\mathrm{R} 2$ is very much like the

\footnotetext{
${ }^{212}$ Edith Hamilton, Mythology (New York: Little, Brown and Company Publishers, 1998).

${ }^{213}$ Star Wars Trilogy, Special Edition, by George Lucas (Fox Searchlight Studios and Lucasfilm Ltd., 1995).
} 
mechanical owl Bubo in the 1981 movie Clash of the Titans which tells a version of the Greek hero Perseus. Bubo the owl is a small robot owl that communicates in a series of squeaks and squeals that only the hero Perseus can understand. ${ }^{214}$ The owl, however, is often a symbol for wisdom and was associated with the goddess Athena as one of her emblems. ${ }^{215}$ R2 is also a small robot who communicates with a series of squeaks and squeals and who can only communicate with $\mathrm{C} 3 \mathrm{PO}$, or with Luke thraugh the aid of a computer translator. As a character R2 is a type of guide who often steers the other characters in the right direction. In Episode IV, for example, R2D2 is the messenger who delivers Princess Leia's distress call to Obi-wan Kenobi and starts Luke Skywalker on the path of the heroic journey. ${ }^{216}$

\footnotetext{
${ }^{214}$ Clash of the Titans, Dir. Desmond Davis (Metro-Goldwyn-Mayer Studios, 1981).

${ }^{215}$ Edith Hamilton, Mythology (New York: Little, Brown and Company Publishers, 1998).

${ }^{216}$ Star Wars Episode IV: A New Hope, Dir. George Lucas (Fox Searchlight Studios and Lucasfilm Ltd., 1977).
} 


\section{CHAPTER VIII}

\section{CONCLUDING REMARKS}

Carl Jung believed that the human race was all connected by what he called the collective unconscious. Jung said this about the collective unconscious:

I have chosen the term 'collective' because this part of the unconscious is not the individual but universal; in contrast to the personal psyche, it has contents and modes of behaviors that are more or less the same everywhere and in all individuals. It is, in other words, identical in all men and thus constitutes a common psychic substrate of a suprapersonal nature which is present in every one of us. ${ }^{217}$

Humans are all exposed to the same basic stimuli and share the same basic needs. We all need to eat, sleep, breathe, and drink. We also all see the same stars if we look into the night sky, see the same sun hovering above us, and rely on the same basic seasons to grow our food. All these similarities are the basis for many of the myths and stories that we as people have created for a very long time, and so it is unsurprising that many of these myths and stories share similarities independent from the culture that gave them birth. Carl Jung believed that the collective unconsciousness was the source of mythological stories because it tapped into human hopes, dreams, and fears. Essentially that is what myths are: people dreaming about overcoming fear which brings about hope.

Authors Joseph Campbell and Vladimir Propp saw that there was a traceable and identifiable pattern to the various myth stories throughout the world. Despite being

${ }^{217}$ Anthony Stevens, Archetypes: A Natural History of the Self (London: Routledge \& Kegan Publishers Ltd., 1983) 14. 
separated by time and geographical location the various myth stories different cultures generated through the collective unconsciousness were similar in structure, content, and intent. Most of the myth stories generated dealt with a heroic character that became a champion of his culture because he accomplished great deeds which were beyond the ability of the average person. The path this hero took was labeled the heroic journey by Joseph Campbell and serves as a map.of the various stages these myth stories will undergo. Filmmaker George Lucas read the work of Campbell and decided to use their work as a framework for his story of Star Wars. ${ }^{218}$

This scholarly work is designed to show the various connections between Star Wars and the mythology of the ancient world. The myths, characters, plots, story lines all existed in another form prior to the release of Star Wars. When audiences see Luke Skywalker first activate his light saber many will simultaneously think of King Arthur pulling the sword from the stone. When they see Anakin Skywalker and Queen Amidala first kiss many will draw a connection between them and another forbidden love story such as Romeo \& Juliet. While not every single audience member will make these connections, many will and each new viewing brings more connections such as these.

Lucas used Campbell as a roadmap when developing the Star Wars saga. Both Luke and Anakin Skywalker follow the heroic journey Campbell laid out in his work. What most people ignore, however, are the influences Campbell drew upon when developing his theories about mythology. Campbell did not simply pluck his theories from the air, but instead read the work of Bastain and Jung which he used to develop the heroic journey. Lucas used the work of Campbell, who had already used the work of Bastain and Jung. And while there is no direct evidence that Vladimir Propp was ever

${ }^{218}$ Joseph Campbell and Bill Moyers, The Power of Myth (New York: Random House Inc., 1991). 
intentionally used by either Campbell or Lucas, his theories were well published and read by many scholars at the time of both Campbell's book and Lucas' movies. Propp is important to the study of mythological stories, and Star Wars certainly fits under that heading.

This scholarly work adds to our understanding of what Star Wars is, how and why it is put together the way it is, and it explores the connections audiences can make when viewing these movies. Lucas thought he could write a story that would appeal to a wide audience because Bastain made a compelling argument for the universality of myth. If Bastain was correct, then Lucas could craft a story that would appeal to a large spectrum of people. Darth Vader is such a great villain because he was modeled after the Jungian archetype of the shadow. If Jung were correct, then Lucas could design a villain that would captivate everyone. The journey Luke and Anakin take is understandable and relatable which makes it interesting to audiences. If Propp was correct, then Lucas could write a story that audiences would find intriguing. Bastain, Jung, and Propp are all important to the study of the Star Wars movies. People always point to Campbell as a huge influence on Lucas, but it is only by looking at Campbell's influences that we truly begin to understand the symbols in Star Wars.

But not everyone sees the same symbols and makes the same connections when viewing Star Wars. Joan Breton Connelly, associate professor of fine arts at NYU, said: 
What's so exciting about approaching the Star Wars cycle, it's very much like an archaeology excavation. On the surface all of us can say 'Ah $\mathrm{Ha}$ Excalibur is to be seen in the light saber.' If you go to a deeper level you may come to the entering to the Death Star and say ' $\mathrm{Ah} \mathrm{Ha}$ let us remember the Greek hero Odysseus and the Underworld.' But then you can go deeper in the stratigraphic levels and... get to a point where I say 'Did George Lucas mean for this connection to be made or am I making it, am I participating as part of the poet, the creator in seeing connections?' And that is the mythological process. Everyone sees themselves. 219

Millions of people have seen the Star Wars movies and millions more will see them in the future. These movies remain poignant because audiences draw some connection to them. For some these movies are nothing more than a kick-ass space action movie with some good acting and a great story. For others these movies are connections to our heritage as human beings because they are the same stories poets and writers have been generating since the ancient world. The Star Wars movies allow us to access our storytelling legacy by tapping into these very relevant themes that have been the themes of other stories for centuries.

Writers have been creating myth stories for so long because they are so easily accessible to so many different people throughout the world. Myth stories have been generated by every culture of people throughout time because, put simply, people love them. Poets and writers have always wanted their stories read and a well cultivated myth story is a safe choice to achieving that goal. Accomplishing a seemingly impossible goal, triumphing over evil, saving the day... are all story elements people enjoy and so creators have crafted many stories with these elements in mind. George Lucas created Star Wars intending people to make these connections between myth and his movies because just like every other writer he wanted people to see his story.

\footnotetext{
${ }^{219}$ Star Wars: The Legacy Revealed, Dir. Kevin Burnes (The History Channel and A \& E Home Video,
} 2007). 
But what separated Lucas from the other writers is that Lucas reached a larger audience than anyone else ever had. Millions upon millions of people have seen, and continue to see the Star Wars movies. The Star Wars saga are not movies that slipped into obscurity but are instead are movies that are still being viewed by legions of viewing audiences. Earlier this year (2012) Lucas began to re-release the Star Wars movies in 3D. The audiences of this re-release are comprised of people who have never seen Star Wars, as well as people who have seen the movies multiple times. Star Wars has not gone away, and each new person who is exposed to Star Wars adds to the mythological experience. That is what sets Lucas apart from the rest, the vast audience he reached with his work.

As a closing thought, I give the last words of this scholarly work to creator George Lucas himself, and what he thinks about his beloved movies. Lucas said:

The appeal of Star Wars has gone beyond anything I could have ever imagined... In the years to come I hope you, your children, and your children's children will enjoy not only this trilogy but also the adventures yet to come in the continually unfolding Star Wars universe. ${ }^{220}$

${ }^{220}$ Star Wars Trilogy, Special Edition, by George Lucas (Fox Searchlight Studios and Lucasfilm Ltd., 1995). 


\section{REFERENCES}

Aeschylus. Orestia. Trans. Peter Meineck. Indianapolis: Hackett Publishing Company Inc., 1998.

Alighieri, Dante. Inferno. Trans. John Ciardi. New York: Random House, Inc., 1996.

Bates, Marilyn, and David Keirsey. Please Understand Me, Character \& Temperament Types. $5^{\text {th }}$ Ed. Del Mar: Prometheus Nemesis Book Company. 1984.

Boethius, Anicius Manlius Severinus. The Consolation of Philosophy. Trans. H.R. James. Oxford: Elliot Stock Printing 1897.

Bradbury, Ray. The Martian Chronicles. New York: Bantam, 1979. Print.

Campbell, Joseph. The Hero with a Thousand Faces. $3^{\text {rd }}$ ed. Princeton: Princeton University Press, 1973.

Campbell, Joseph, and Bill Moyers. The Power of Myth. New York: Random House Inc., 1991.

Clark, Lynn. From Angles to Aliens, Teenager, the Media, and the Supernatural. New York: Oxford University Press, 2003.

Clash of the Titans. Dir. Desmond Davis. Metro-Goldwyn-Mayer Studios and Turner Entertainment Company, 1981. DVD.

Coogan, Michael. The New Oxford Annotated Bible. $3^{\text {rd }}$ ed. New York: Oxford University Press, 2001.

Cotterell, Aurthur, and Rachel Storm. The Ultimate Encyclopedia of Mythology. New York: Anness Publishing Limited, 2003.

Decker, Kevin S., and Jason T. Eberl. Star Wars and Philosophy. Chicago: Open Court Publishers, 2005.

Dundes, Alan. "Folkloristics in the Twenty-First Centry." Journal of American Folklore. No. 470. Chicago: University of Illinois Press, 2005. 385-408. 
Eliade, Mircea. Patterns in Comparative Religion. Trans. Rosemary Sheed. Lincoln: University of Nebraska Press, 1996.

Euripides. Euripides I, The Complete Greek Tragedies. Ed. David Grene and Richmond Lattimore. Chicago: University of Chicago Press. 1955.

Ferré, John. Channels of Belief, Religion and American Commercial Television. Ames: Iowa State University Press. 1990.

Flowers, Betty Sue. The Power of Myth. New York: Doubleday Publishers. 1988.

Forty, Jo. Mythology, A Visual Encyclopedia. New York: PCR Publishing Ltd. 1999.

"George Lucas ranks 316 on The World's Billionaires" 2010. Forbes. 3 Oct. 2010.

Goulart, Ron. Great American Comic Books. Lincolnwood: Publications International Ltd. 2001.

Hamilton, Edith. Mythology. New York: Little, Brown and Company Publishers. 1998.

Henderson, Mary. Star Wars, The Magic of Myth. New York: Bantam Spectra Books, Doubleday Dell Publishing Group Inc. 1997.

Hick, John. An Interpretation of Religion, Human Responses to the Transcendent. $2^{\text {nd }}$ Ed. New Haven: Yale University Press. 2004.

Homer. The Iliad. Trans. W.H.D. Rouse. New York: Penguin Books Group. 1938.

Homer. The Odyssey. Trans. W.H.D. Rouse. New York: Penguin Books Group. 1938.

In Search of History - Oracle At Delphi (History Channel). A\&E Home Video. 2006. DVD.

Jenkins, Henry. Convergence Culture, Where Old, and New Media Collide. New York: New York University Press. 2006.

Johnson, Elizabeth. She Who Is, The Mystery of God in Feminist Theological Discourse. $10^{\text {th }}$ Ed. New York: The Crossroad Publishing Company. 2003.

Johnson, Robert. He, Understanding Masculine Psychology. New York: Harper \& Row Publishers. 1989.

Johnson, Robert. She, Understanding Feminine Psychology. New York: Harper \& Row Publishers. 1989. 
Jones, Steven. The Fairy Tale: The Magic Mirror of the Imagination. London: Routledge Publishers. 2004.

Jung, Carl. Archetypes and the Collective Unconscious. Princeton: Princeton University Press. 1959.

Knowles, James. The Legends of King Arthur and His Knights. Create Space Publishers. 2012.

Koepping, Klaus-Peter. Adolf Bastian and the Psychic Unity of Mankind: The Foundations of Anthropology in Nineteenth Century Germany. St. Lucia: University of Queensland Press. 1983.

Kurtz, Lester. Gods in the Global Village, The World's Religions in Sociological Perspective. Thousand Oaks: Pine Forge Press. 1995.

Larsen, Stephen, and Robin Larsen. Joseph Campbell: A Fire in the Mind. Rochester: Inner Traditions Press. 2002.

Malory, Thomas. Le Morte D'Arthur, King Arthur and of his Noble Knights of the Round Table. London: Simon \& Brown Publishers. 2011.

Martin, Joel, and Conrad Ostwalt Jr. Screening the Sacred: Religion, Myth, and Ideology in Popular American Film. Boulder: Westview Press Inc. 1995

Miller, Barbara. Cultural Anthropology. $2^{\text {nd }}$ Ed. Washington D.C.: George Washington University Press. 2002.

Milton, John. Paradise Lost. New York: Oxford University Press. 2005.

Molloy, Michael. Experiencing the World's Religions: Tradition, Challenge, and Change. $5^{\text {th }}$ Ed. New York: McGraw-Hill Publishers. 2010.

Paden, William. Religious Worlds, The Comparative Study of Religion. Boston: Beacon Press. 1994.

Propp, Vladimir. Theory and History of Folklore. Trans. Ariadna Martin and Richard Martin. Minneapolis: University of Minnesota Press. 1984.

Propp, Vladimir. Morphology of the Folktale. $19^{\text {th }}$ Ed. Trans. Laurence Scott. Austin: University of Texas Press. 2008.

Rise and Fall of the Spartans, Dir. John Jopson and Patrick Taulère. The History Channel: A \& E Home Video. 2002. DVD. 
Sansweet, Stephen. Star Wars Encylopedia. New York: Random House Inc., and Lucasfilm Ltd. 1998.

Shakespeare, William. William Shakespeare: The Complete Works. New York: Oxford University Press. 1998.

Slavicsek, Bill. A Guide to the Star Wars Universe. $2^{\text {nd }}$ Ed. New York: Del Rey Books. 1994.

Sporre, Dennis. Perceiving the Arts, An Introduction to the Humanities. $10^{\text {th }}$ Ed. Saddle River: Pearson Prentice Hall. 2011.

Sophocles. The Theban Plays. Trans. David Grene. Chicago: University of Chicago Press. 1994.

Star Wars, Episode I: The Phantom Menace. Dir. George Lucas. Fox Search Light Studios, and Lucasfilm Ltd. 1999. DVD.

Star Wars, Episode II: Attach of the Clones. Dir. George Lucas. Fox Search Light Studios, and Lucasfilm Ltd. 2002. DVD.

Star Wars, Episode III: Revenge of the Sith. Dir. George Lucas. Fox Search Light Studios, and Lucasfilm Ltd. 2005.

Star Wars: The Legacy Revealed. Dir. Kevin Burnes. The History Channel and Lucasfilm Ltd., Prometheus Entertainment Corporation, 2007. DVD.

Star Wars Trilogy: Star Wars, The Empire Strikes Back, and Return of the Jedi. Dir. George Lucas, Irvin Kershner, and Richard Marquand. Fox Search Light Studios and Lucasfilm Ltd. 1995. VHS.

Stevens, Anthony. Archetypes, A Natural History of the Self. $1^{\text {st }}$ Quill Edition. London: Routledge \& Kegan Publishers Ltd. 1983.

St. Clair, Robert. Literary Structures, Character Development, and Dramaturgical Scenarios in Framing the Category Novel. Lewiston: The Edwin Mellen Press. 2004.

Swann, Steven. The Fairy Tale: The Magic Mirror of the Imagination. London: Routledge Publishing. 2003.

The Mythology of Star Wars. Produced by George Lucas and Bill Moyers. For the Humanities Production Company: Public Broadcast Services. 2000.

The Wizard of $\mathrm{Oz}$. Dir. Victor Fleming. Metro-Goldwyn-Mayer Studios and Warner Brothers Home Movie Studios. 1939. DVD. 
Tillich, Paul. Dynamics Of Faith. New York: HooperCollins Publishers Inc. 1957. Tylor, Edward B. "Professor Adolf Bastian." Man 5:138-143. 1905.

Tylor, Edward B. Primitive Culture. New York: J.P. Putnam's Sons. 1920.

Virgil. The Aeneid. Trans. Robert Fitzgerald. New York: Random House Inc. 1990.

Wilson, Karina. Propp's Analysis of Folktale. Mediaknowall.com. 2011. Web. 


\section{Email Correspondence: Joseph Campbell Foundation}

I apologize for the delay in my response; we're a small organization with a part-time staff, and have all of the pleasures and frustrations attendant thereto.

Part of the delay was the fact that the question took me longer to answer than I anticipated; it's more difficult to prove a negative than a positive, and an unexpected negative result is most difficult of all. I've looked through all of the material that I have -all of Campbell's published and most of his unpublished work -- and was rather surprised to find no reference to Vladimir Propp or his work. I would be shocked if Campbell hadn't read Morphology of the Folk Tale, since it was very much in his area of interest and came out while Campbell was a graduate student in Paris. I will say that -- if you're a big believer in schools of criticism -- Campbell was a Structuralist, rather than a follower of Propp's Formalist school, though I must also admit that Campbell would most likely have rejected that kind of reductionist labeling.

I checked the OPUS Archives Joseph Campbell Collection, which houses (among other things) Campbell's book collection (the marginalia are fascinating, if you ever get the chance to visit), and found nothing there, so I'm afraid I can't help you. If it's any consolation, I went through a similarly futile search a few years ago, sure that I would some reference to the work of another professor whose work paralleled Campbell's own: JRR Tolkien.

I think it shouldn't be hard, however, to show that Propp's work influenced Campbell's, even if only indirectly. I wish you the best of luck in your work, little as I was able to help you.

David Kudler

Joseph Campbell Foundation Publications

www.jcf.org • publications@icf.org

415-601-3402 (cell)

The privilege of a lifetime is being who you are.

--Joseph Campbell, The Joseph Campbell Companion 


\section{CURRICULUM VITAE}

NAME: $\quad$ Aaron Louis Nusz

ADDRESS: Department of Humanities

505 Buffalo Run Road

Jefferson Community and Technical College

Shepherdsville KY 40165

DOB: $\quad$ Elizabethtown, Kentucky-December 31, 1979

EDUCATION

\& TRAINING: $\quad$ B.A., Anthropology

University of Louisville

1999-2004

PROFESSIONAL

SOCIETIES: $\quad$ North American Anthropology Association

Kentucky Archaeological Association 